INTER NATIONAL MONETARY FUND

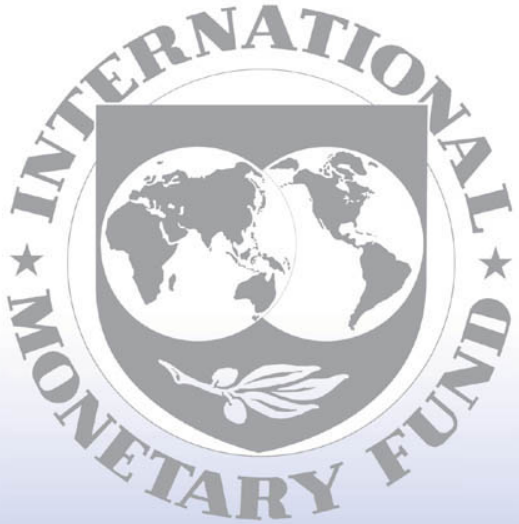

Staff

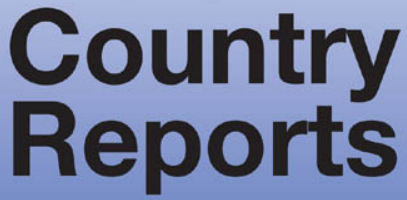




\section{Honduras: Request for Stand-By Arrangement_-Staff Report; Staff Statement; Press Release on the Executive Board Discussion; and Statement by the Executive Director for Honduras}

In the context of the request for Stand-By Arrangement, the following documents have been released and are included in this package:

- The staff report for the Request for Stand-By Arrangement prepared by a staff team of the IMF, following discussions that ended on February 29, 2008, with the officials of Honduras on economic developments and policies. Based on information available at the time of these discussions, the staff report was completed on March 25, 2008. The views expressed in the staff report are those of the staff team and do not necessarily reflect the views of the Executive Board of the IMF.

- A staff statement of April 7, 2008 updating information on recent developments.

- $\quad$ A Press Release summarizing the views of the Executive Board as expressed during its April 7, 2008 discussion of the staff report that approved the Stand-By Arrangement.

- A statement by the Executive Director for Honduras.

The documents listed below have been separately released.

Letter of Intent sent to the IMF by the authorities of Honduras*

Memorandum of Economic and Financial Policies by the authorities of Honduras*

Technical Memorandum of Understanding*

*Also included in Staff Report

The policy of publication of staff reports and other documents allows for the deletion of marketsensitive information.

Copies of this report are available to the public from

International Monetary Fund • Publication Services

$70019^{\text {th }}$ Street, N.W. • Washington, D.C. 20431

Telephone: (202) 623-7430 • Telefax: (202) 623-7201

E-mail: publications@imf.org •Internet: http://www.imf.org

Price: $\$ 18.00$ a copy

International Monetary Fund

Washington, D.C. 
This page intentionally left blank

(C)International Monetary Fund. Not for Redistribution 


\section{INTERNATIONAL MONETARY FUND}

\section{HONDURAS}

\section{Request for Stand-By Arrangement}

Prepared by the Western Hemisphere Department

(in consultation with other departments)

Approved by David J. Robinson and Adnan Mazarei

March 25, 2008

- Discussions. Discussions were held in Washington during January 24 to February 8 and February 19-29, 2008. The staff team comprised Messrs. A. Lṕez-Mejá (Head), G. Bannister, G. Callegari (all WHD); F. Bornhorst (FAD); P. Dudine (PDR); and M. Garza (Resident Representative). Mr. D.J. Robinson (WHD) participated in some of the discussions. Messrs. J.A. Rojas and A. Umañ a (OED) also joined some discussions. On February 7, Management (Mr. Portugal) met with President Zelaya and the economic team.

- Fund relations. Honduras has had three previous PRGF arrangements, the last of which expired in February 2007, with the fourth review (scheduled for April 2006) not completed due to the lack of agreement on key fiscal policies. The 2006 Article IV discussion was held in February 2007. At end-January 2008, Honduras' outstanding Fund credit was SDR 20.3 million (15.7 percent of quota), all from the PRGF. Honduras' most recent Stand-By Arrangement expired in 1992.

- New program. In the attached Letter of Intent and Memorandum of Economic and Financial Policies (MEFP), the authorities describe their economic program for 2008, for which they request support under a 12-month Stand-By Arrangement in an amount equivalent to SDR 38.85 million (30 percent of quota). The authorities intend to treat the program as precautionary. 


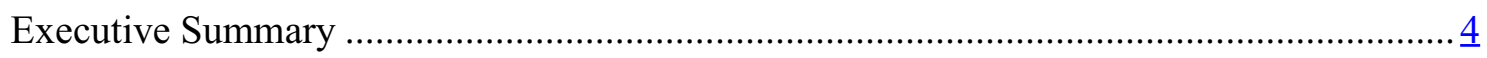

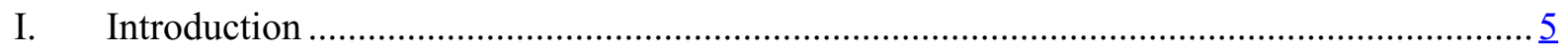

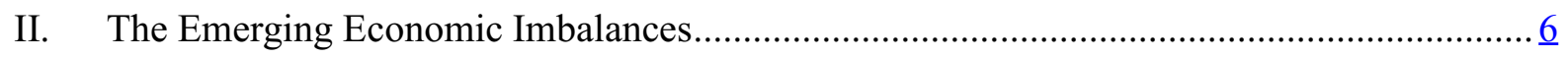

III. The Stabilization Program: Addressing Economic Imbalances ........................................... 9

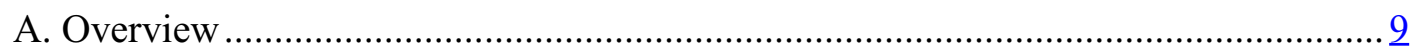

B. Fiscal Consolidation and Reorientation ...........................................................11

C. Containing Inflation and Safeguarding External Stability ....................................13

D. Strengthening the Energy Sector.......................................................................

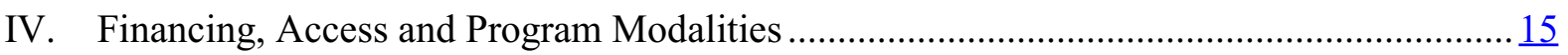

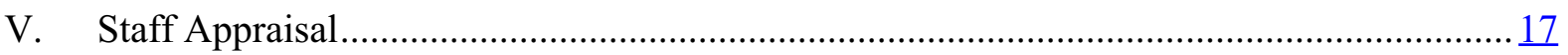

Figure

1. Macroeconomic Performance-Imbalances are Growing …………….............................. 7

Tables

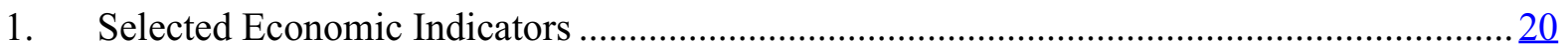

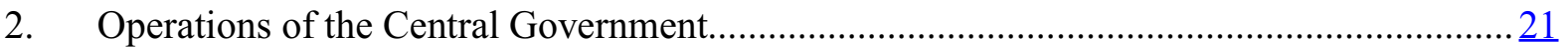

2a. Operations of the Central Government - Quarterly ..........................................................22

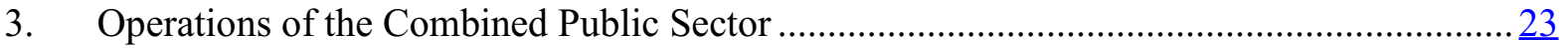

3a. Operations of the Combined Public Sector - Quarterly …………………………….......... 24

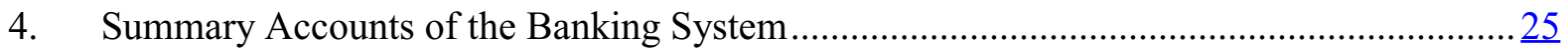

4a. Summary Accounts of the Banking System - Quarterly ……………………………….... 26

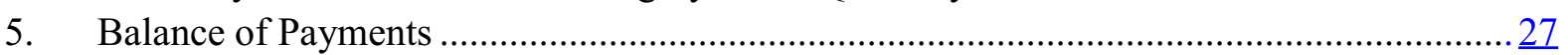

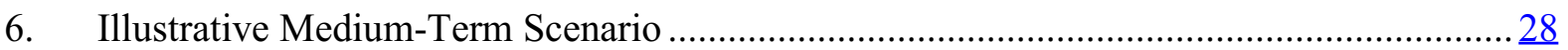

7. Purchase Schedule and Terms under Proposed Stand-By Arrangement...............................28

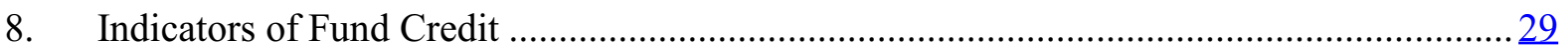

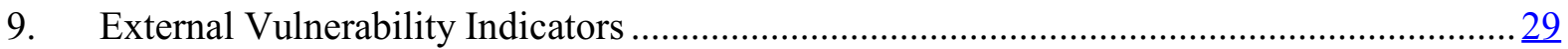

10. Structure and Performance of the Banking Sector ............................................................ 
Appendices

I. Attachment I. The Authorities' Letter........................................................................

Attachment II. Memorandum of Economic and Financial Policies ...................................... $\underline{32}$

Attachment III. Technical Memorandum of Understanding ............................................... $\underline{38}$

II. Assessing External and Public Sector Debt Sustainability................................................. 43

Appendix Tables

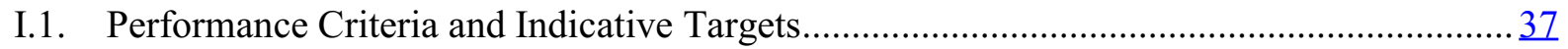

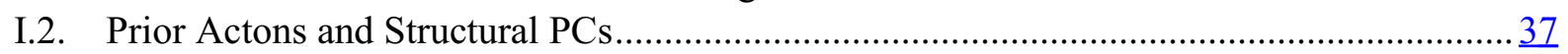

II.1. External Debt Sustainability Framework, Baseline Scenario, 2005-2028......................... 45

II.2a. Sensitivity Analyses for Key Indicators of Public and Publicly Guaranteed

External Debt, 2008-28........................................................................................ 46

II.2b. Sensitivity Analyses for Key Indicators of Public and Publicly Guaranteed

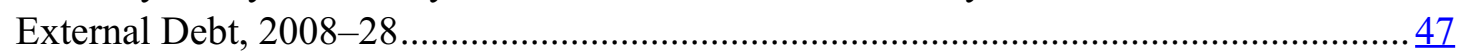

II.3. Sensitivity Analysis for Key Indicators of Public Debt, 2008-2028 …………………... $\underline{48}$

II.4. Public Sector Debt Sustainability Framework, Baseline Scenario, 2005-2028................... 49

Appendix Figures

II.1. Indicators of Public and Publicly Guaranteed External Debt Under Alternative

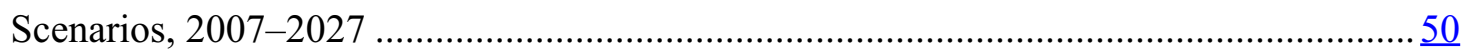

II.2. Indicators of Public Debt Under Alternative Scenarios, 2008-2028 ………………....... 51

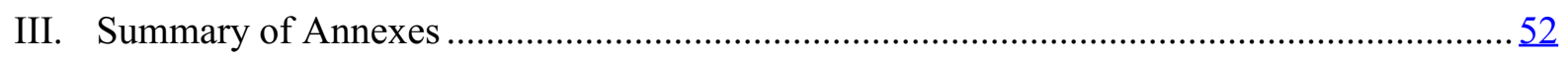




\section{EXECUTIVE SUMMARY}

\section{Background}

- Honduras has had three previous PRGF arrangements, the last of which ended in February 2007. The most recent PRGF program focused on fiscal consolidation and structural reforms to strengthen growth and reduce vulnerabilities in the financial sector. However, the program went off track due to large wage increases granted in 2006, including a 4-year agreement with teachers.

- Over the last year, expansionary policies led to emerging imbalances. While growth remains robust and macroeconomic stability has been maintained, in 2007 inflation increased, bank credit expanded rapidly and led to a boom in imports, a sharp weakening in the external current account deficit, and a loss of net international reserves. At the same time, the overall fiscal deficit deteriorated, partly reflecting the weakening finances of the public electricity company (ENEE).

- $\quad$ The authorities are requesting a 12-month $S B A$ covering economic policies through December 2008. They consider that Fund support for their program will help anchor economic policymaking ahead of primary elections, reinforce confidence and unlock donor financing. They do not intend to draw under the arrangement, and view it as a bridge to a PRGF to be negotiated before end-year.

\section{Program objectives and staff appraisal}

- $\quad$ The authorities' program is centered on strengthening macroeconomic stability through policies in three key areas:

$>$ Fiscal consolidation and reorientation. The overall fiscal deficit will be reduced to $1 \frac{1}{2}$ percent of GDP in 2008 , from $2 \frac{1}{4}$ in 2007 . This is consistent with a stable wage bill, a recovery in priority spending, and a stable debt-to-GDP ratio.

> Containing inflation and safeguarding external stability. The monetary program seeks to maintain single digit inflation, bring credit growth to sustainable levels, and build up net international reserves. The program also envisages prudential measures to encourage banks to internalize risks from rapid credit expansion. The existing exchange rate band will be used more actively to help maintain external competitiveness and an adequate level of foreign reserves.

Strengthening the energy sector. In collaboration with the World Bank and the IADB, the program envisages the implementation of a tariff policy that covers operational costs of the electricity company and the clearance of arrears with private generators.

- In the staff's view, the authorities' program appropriately addresses emerging imbalances. Risks include a less favorable external environment and pressures for domestic expansionary policies ahead of primary elections scheduled for late 2008. Staff welcome the authorities' prior actions, which are an important signal of the government's commitment to the program, but underscore the need to react promptly to changes in the external environment and resist pressures for a loosening of policies. 


\section{INTRODUCTION}

1. Honduras is among the poorest countries in the region and has historically experienced low and volatile growth. Long-standing institutional problems have weakened economic growth, and policymaking has been constrained by short political cycles, pressure from vested interests, governance challenges, and intermittent social unrest. At the same time, external shocks, including hurricanes and terms-of-trade changes, have contributed to the volatility of output. As a result, social indicators remain among the weakest in Latin America, with an unequal distribution of income and a third of the population living on under US $\$ 2$ a day.

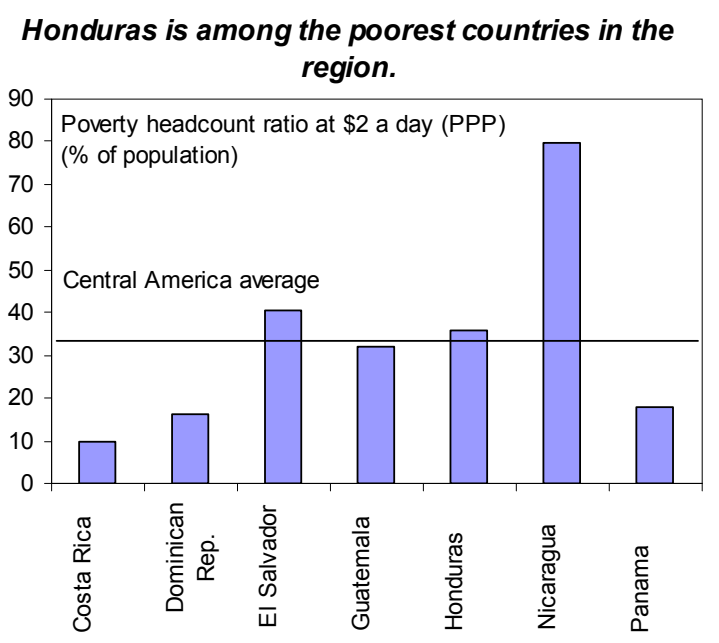

\section{The previous PRGF, approved in 2004, focused on fiscal consolidation and} structural reforms to strengthen growth and reduce vulnerabilities in the financial sector. A key to restoring sustainability to the public finances was the reduction in the civil service wage bill in terms of GDP, a tax reform, and improved tax administration. To address bank fragilities resulting from the devastation of Hurricane Mitch in 1998, the financial sector was strengthened through an upgrading of the legal, prudential, and supervision frameworks. Key medium-term reforms were oriented at strengthening the central bank and monetary policy operations, the banking commission (CNBS), and the tax administration office (DEI). In addition, Honduras obtained debt relief from the Enhanced HIPC Initiative, Paris Club creditors, the MDRI, and the IADB, bringing its external debt down from 78 percent of GDP in 1999 to 16 percent in 2007.

\section{Social pressures, however, led to an unwinding of key fiscal reforms and the} introduction of procyclical policies in 2006. Having won the end-2005 elections by a small margin, the new government took office without a congressional majority and with difficulties in forging political alliances. Against a backdrop of social unrest fueled by rising oil prices and the expectation of higher spending following debt relief, the government granted substantial concessions on public wages (including a 4-year agreement with teachers), reinstated fuel subsidies, and froze fuel and electricity prices. Moreover, the central bank eased monetary policy by lowering interest rates and reducing liquidity requirements on dollar bank deposits. As a result, the fourth review of the PRGF, scheduled for April 2006, was not completed due to the lack of agreement on key policies, and the program expired in February 2007. 


\section{The EMERGING ECONOMIC IMbalanCES}

\section{Economic imbalances grew over the last}

year. While growth remains robust and

macroeconomic stability has been maintained, inflation increased to near 9 percent last

December (from 5.3 percent in 2006), among the highest in the region and above the authorities' target range (5-6 percent), boosted by rising oil and food prices. Also, despite an improvement in the terms of trade and good export performance in 2007, the external current account deficit almost doubled (reaching 10 percent of GDP) due to the rapid growth of imports, and net international reserves began to decline (Figure 1).

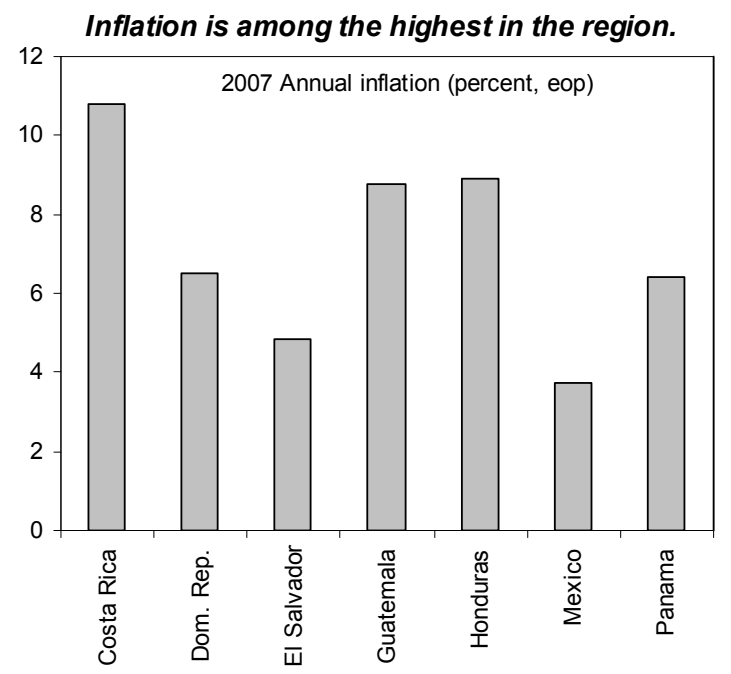

5. These imbalances have largely reflected expansionary macro policies. In particular:

- $\quad$ Fiscal policy. The overall fiscal deficit has deteriorated since 2005 and the quality of public spending weakened. Although tax revenue has been buoyant, the rapid rise in the wage bill and untargeted subsidies have crowded out public investment and social spending, posing risks to fiscal sustainability. Reflecting rising employment and large wage increases granted in 2006, the central government wage bill increased 25 percent in 2007 (33 percent for teachers). The combined public sector wage in 2007 is estimated at 11.7 percent of GDP, one of the highest in the region. Net lending from the public pension institutes also contributed to growth in the overall deficit.

The deficit is increasing and the quality of spending is deteriorating.

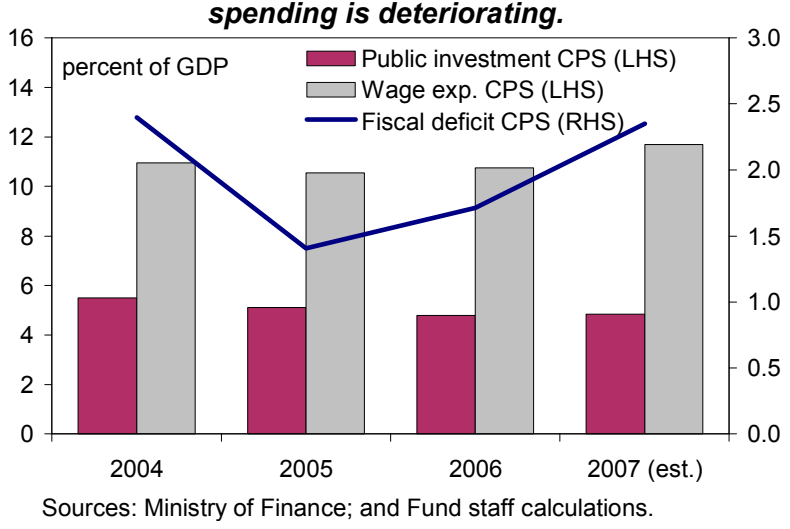

The wage bill is the highest in the region.

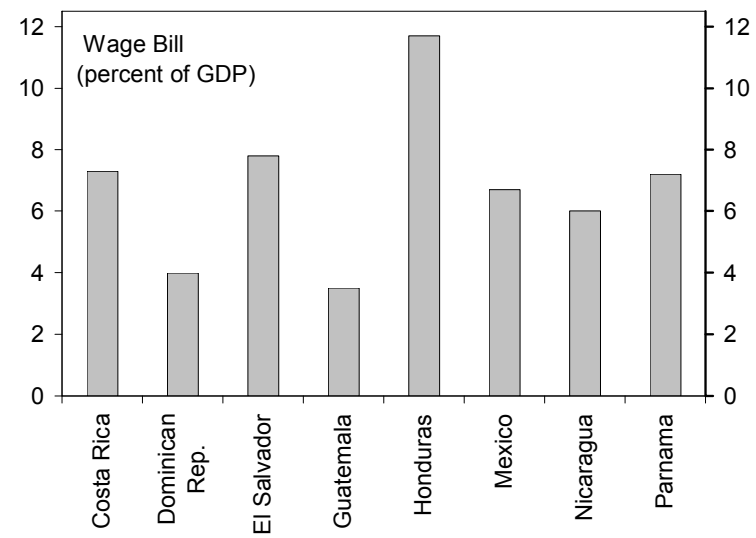

Source: Fund staff estimates (estimates 2007). 
Figure 1. Honduras: Macroeconomic Performance-Imbalances are Growing

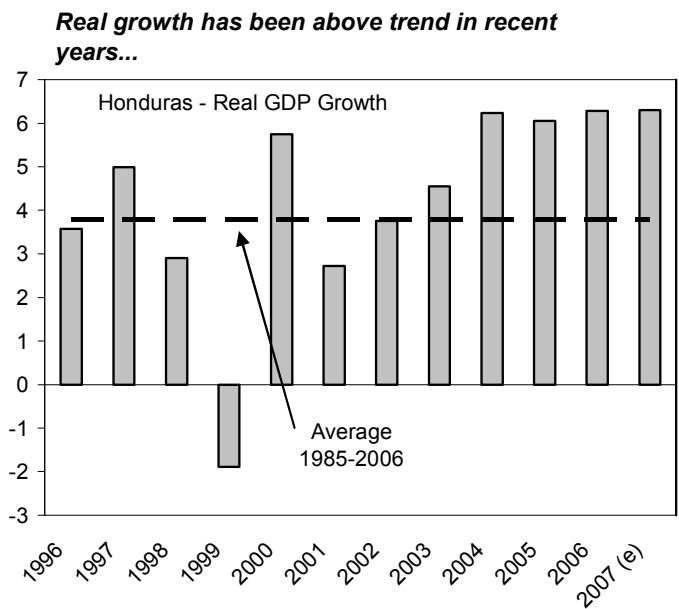

Despite recent tightening, real interest rates remain negative...

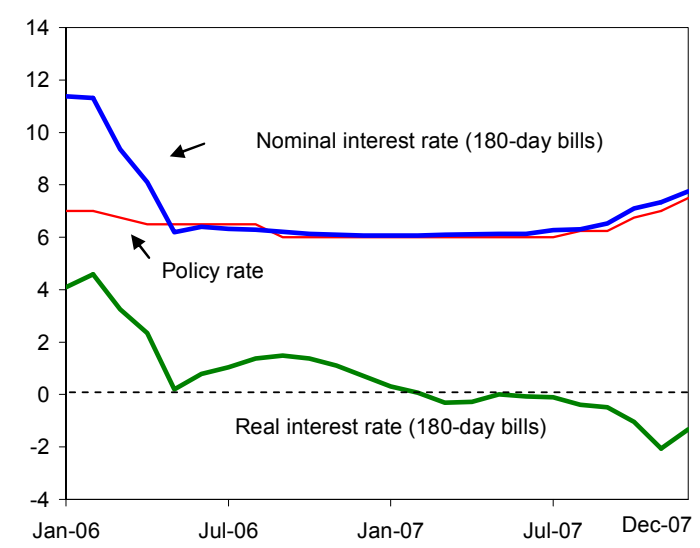

Increasing domestic demand led to a deterioration in the current account...

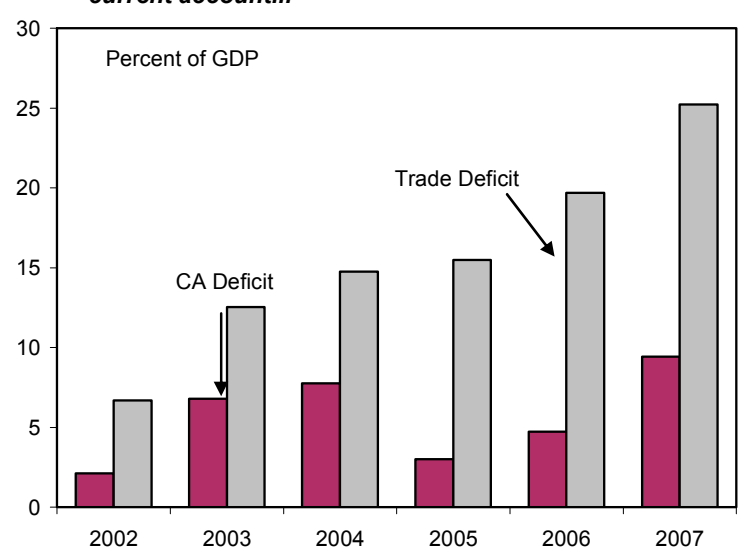

Sources: Central Bank of Honduras; and Fund staff estimates.
... and inflation has been increasing.

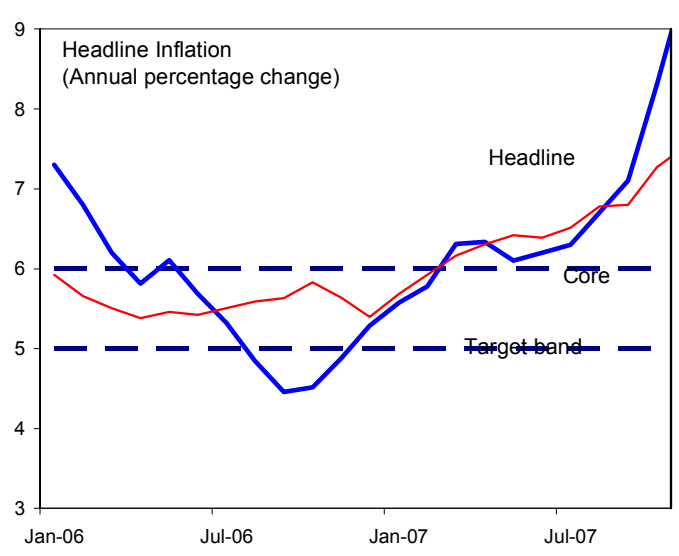

... with expansionary policies leading to a rapid increase in bank credit.

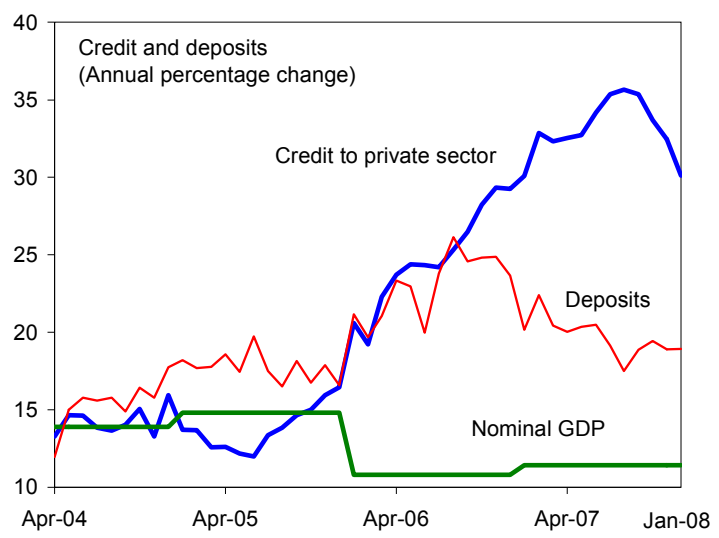

..and to a decline in NIR.

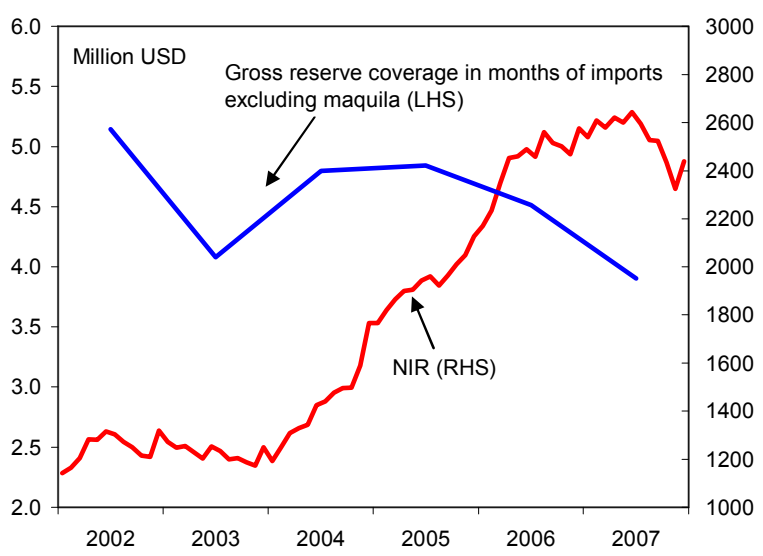


- Monetary policy. An accommodative monetary policy and competition for market share among domestic banks in response to the entry of foreign banks led to a rapid rise in bank credit (over 30 percent year-on-year) and a boom in imports, posing risks to financial sector health and external stability. In response, the central bank raised policy interest rates by 150 basis points to 7.5 percent in the second half of 2007 and increased

The monetary stance is expansionary, and the stock of open market bills has fallen.

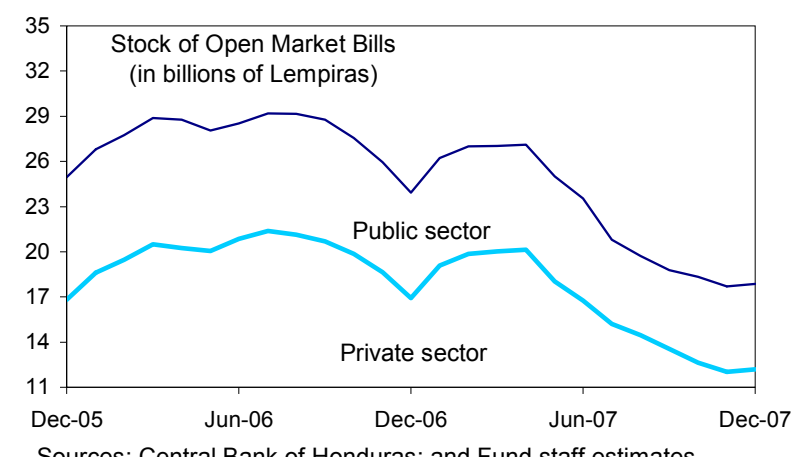

Sources: Central Bank of Honduras; and Fund staff estimates. reserve requirements, but real interest rates remain negative and the outstanding stock of central bank paper has declined.

- $\quad$ Exchange rate policy. The official exchange rate regime allows the Lempira to fluctuate within $\mathrm{a} \pm 7$ percent crawling band, but it has been pegged at the most appreciated side of the band since 1999, and the band has been fixed since October 2005. With a de facto fixed exchange rate and expansionary fiscal and monetary policies, net international reserves fell by US $\$ 102$ million in 2007. While the real effective exchange rate appreciated marginally in the context of a fixed nominal exchange rate, staff estimates of the real exchange rate suggest there is no significant misalignment.

The REER has appreciated in the context of a stable nominal exchange rate...

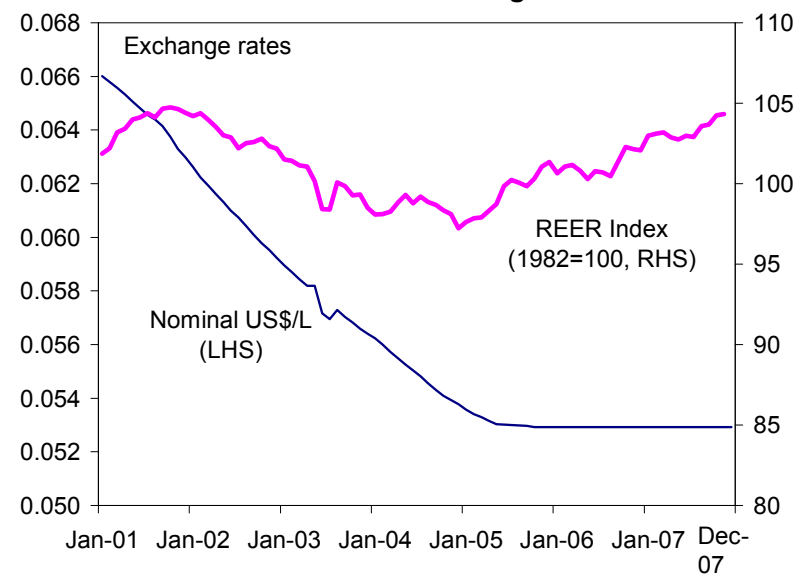

Sources: Country authorities; and Fund staff calculations.

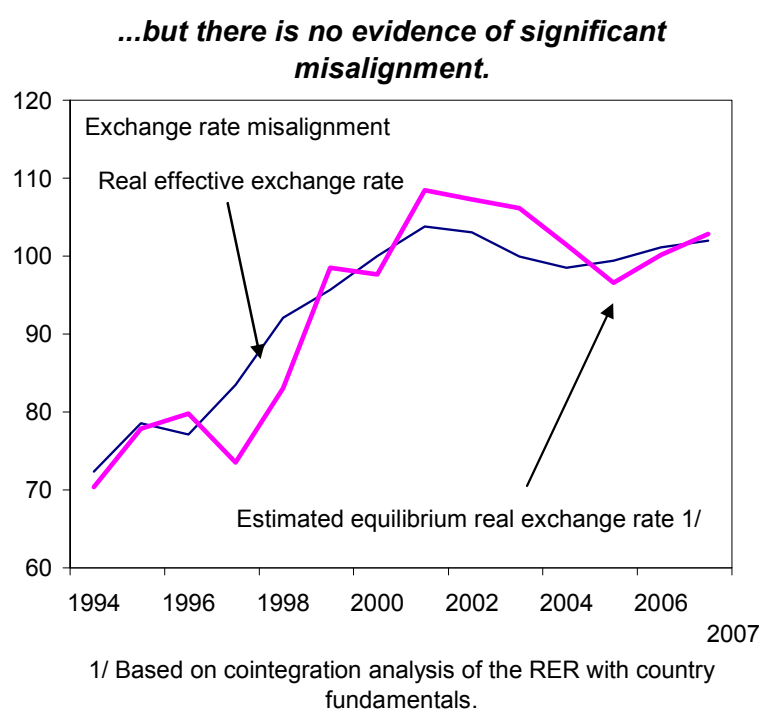


6. Emerging imbalances are also associated with weaknesses in the energy sector, which pose risks to the public finances, the financial system, and growth. From April 2006 to December 2007 electricity tariffs remained fixed, while fuel costs rose by 50 percent (to US\$75 per barrel of bunker, from about US\$50). As a result, the losses of the public electricity firm ENEE increased and led to a significant weakening of the overall operating balance of state enterprises. The losses of ENEE were financed with payment arrears to private generators, and contractors (about 1.6 percent of GDP), as well as transfers

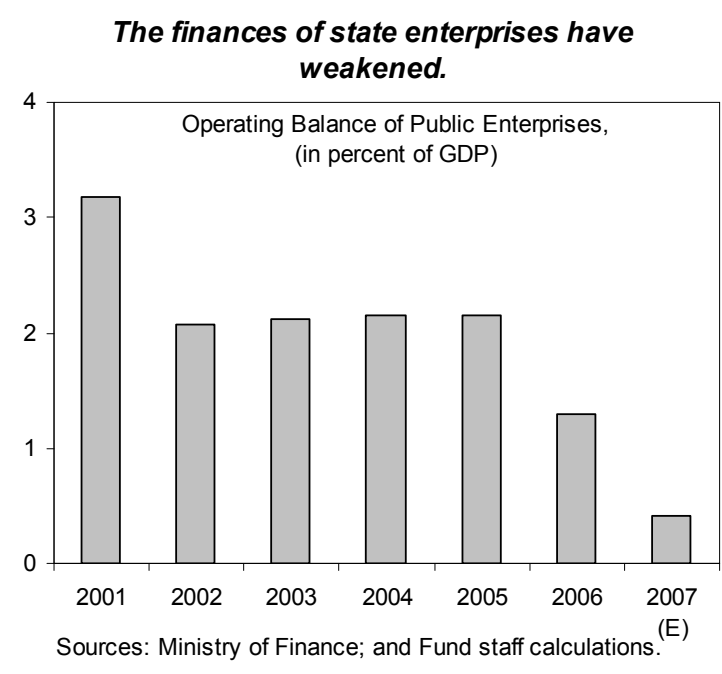
from the government, and short-term bank credit. Moreover, subsidies have kept domestic fuel prices fixed at below international prices and have been financed by squeezing importers' profit margins and with direct transfers from the budget. Overall energy subsidies in 2007, including losses of ENEE, are estimated at over 2 percent of GDP. At the same time, the two largest banks (about 30 percent of financial sector assets) and a medium-sized bank each had over 30 percent of capital exposed to the energy sector.

\section{The Stabilization Program: Addressing Economic Imbalances}

\section{A. Overview}

7. The authorities' program for 2008 aims at strengthening the conditions for sustained growth and poverty reduction through the consolidation of macroeconomic stability. The program focuses on policies in three key areas: fiscal policy will be tightened and the public sector wage bill stabilized to help keep public debt broadly constant and redirect spending to priority sectors; monetary policy will be geared to contain inflation and achieve the NIR target, while bringing credit growth down to more sustainable levels. Exchange rate policy will use the existing band more actively to support monetary policy and help maintain external competitiveness; the energy sector will be strengthened in collaboration with the World Bank and the IADB, by implementing electricity tariff reform to cover the operational costs of ENEE and clearing ENEE arrears with private generators.

\section{The authorities believe that a 12-month precautionary $S B A$ would reinforce} confidence and support their economic program for 2008, while providing a bridge to a Poverty Reduction and Growth Facility (PRGF) later in the year. ${ }^{1}$ With a precautionary SBA

\footnotetext{
${ }^{1}$ A precautionary SBA is more appropriate than a Policy Support Instrument (PSI) given Honduras' uneven performance under previous PRGF's and because the authorities have yet to finalize a three-year policy framework and policy matrix.
} 
in place, the existing financing gap is expected to be covered by concessional flows. At the same time, acknowledging that a PRGF is better suited to address Honduras' structural challenges, the authorities intend to develop the political consensus needed to finalize a medium-term plan with policies for poverty alleviation and growth. The plan is expected to include a medium-term fiscal framework, a comprehensive civil service reform, and polices to enhance the transparency of the budgetary process, continue strengthening the energy and financial sectors and public institutions, and improve the business climate. A successful transition to a new PRGF will require satisfactory performance under the SBA, budget discipline and expenditure control, an appropriate mix of monetary and exchange rate policies, an updated Poverty Reduction Strategy Paper (PRSP), and clarity about a medium-term expenditure framework. In coming months, the authorities plan to update the July 2001 PRSP through 2015 to ensure progress towards the poverty-reduction goals. The updated PRSP will give priority to developing a medium-term macroeconomic framework, and improving the alignment between public expenditure and poverty reduction.

\section{The authorities,}

\section{program is designed to} preserve growth and contain inflation within a less favorable external environment. Growth is projected to abate from over 6 percent in 2007 to $43 / 4$ percent in 2008, largely reflecting a slowdown in the world economy, with monthly indicators pointing to a deceleration in economic activity since late 2007. Inflation is expected to remain at about 9 percent, driven by increases in electricity tariffs, a decline in fuel subsidies, and rising wages (e.g. the minimum wage was increased by 11 percent). Despite an expected deterioration in the terms of trade, the external current account deficit would start declining gradually and gross international reserves would be maintained at 4 months of nonmaquila imports.

\section{Near-term risks are somewhat tilted to the downside. While a Fund-supported} program could reinforce confidence and help anchor economic policy making, a higher-thananticipated slowdown in the U.S. economy could adversely affect remittances and exports. Staff research suggests that a 1 percent deceleration in the U.S. would lead to a similar slowdown of the Honduran economy. Other downside risks include higher fuel prices and pressures for expansionary policies in the run-up to primary elections scheduled for late 2008. It will be important to monitor economic developments closely and strengthen the program, if necessary, to help ensure macroeconomic imbalances are reduced. 


\section{B. Fiscal Consolidation and Reorientation}

11. Under the program, the overall deficit of the combined public sector will decline from $21 / 4$ percent of GDP in 2007 to $1 \frac{1}{2}$ percent in 2008 . This represents an underlying adjustment of about 2 percent of GDP, compared to a passive scenario in which no measures are taken. The deficit target is expected to be in line with the budget to be approved by congress in April (prior action) and will help keep public debt broadly stable at about 221/2 percent of GDP (MEFP \ 5). The authorities'intention to redirect spending to priority sectors, particularly public investment, will be instrumental to sustain growth and reduce poverty.

\section{Fiscal consolidation is being achieved through a mix of revenue and expenditure}

measures. On the revenue side, tax administration and policy are being strengthened and the decision to make the solidarity tax permanent has prevented a decline in tax revenues; new services charges in the public telecommunication company will increase nontax revenues; electricity tariffs were raised in January and a new tariff structure will come into effect in April (see section on energy policy), which fully covers the operational cost of the electricity company (ENEE) (structural performance criterion). On the expenditure side, the authorities are committed to keep a tight lid on current primary spending of the central government (indicative ceiling) and increase public investment in infrastructure projects to reduce bottlenecks in the electricity sector and improve transport infrastructure. Conscious of the need to protect the poor, the authorities are improving the targeting of electricity and direct fuel subsidies while reducing their overall level. Staff encouraged the authorities to strengthen further the targeting of subsidies, including through a gradual lifting of price ceilings on gasoline and diesel, while continuing to subsidize cooking gas and kerosene, in line with recent Fund TA advice. The policy of no new net lending by public pension funds will help curtail spending, limit risk in their portfolios, and protect their financial integrity.

13. The stabilization of the wage bill is a key objective of the program. Containing the rapid rise in the wage bill will help attain the inflation objective, create space for priority spending, and support fiscal sustainability. In collaboration with the World Bank, structural reform measures will need to be implemented to bring the wage bill under better control in the medium term. In the meantime, there was agreement to stabilize the central government wage bill at 9.2 percent of GDP in 2008 and to reduce it to 9.1 percent of GDP in 2009 (indicative 
target), with the overall public sector wage bill contained at 11.4 percent of GDP in 2008, below 2007 levels. In order to achieve these goals, the authorities will:

- Implement moderate wage increases. There will be no further wage or benefit increases for teachers beyond the 2006 agreement (which stipulates fixed nominal wage and benefit increases for 2008-09) — and nominal wage increases for other civil servants will be in line with projected inflation.

- Control public employment. There will be no increase in net employment at the central government, with the planned hiring of teachers, policemen, and health workers fully compensated by retirements and other separations. Actions will be taken to tighten payroll control, including: establishing a centralized unit for payroll management at the ministry of finance; incorporating payroll management systems into the integrated financial management system (SIAFI); acting on irregularities revealed by a census and audit of teachers (including stopping payment and initiating legal actions), and extending the audit to the rest of the central government. Also, restructuring plans for the two largest state enterprises will be completed in late 2008.

\section{The budget is financed entirely through} concessional foreign lending. External

concessional loans and proceeds from the sale of a cellular license band will exceed budgetary financing needs, allowing for negative domestic financing, reducing budgetary costs and supporting monetary policy. It will also help ensure a stable debt-to-GDP ratio over the medium term as external financing will be contracted only on concessional terms. After receiving over US\$3 billion of debt relief, the NPV of Honduras' external public debt is about

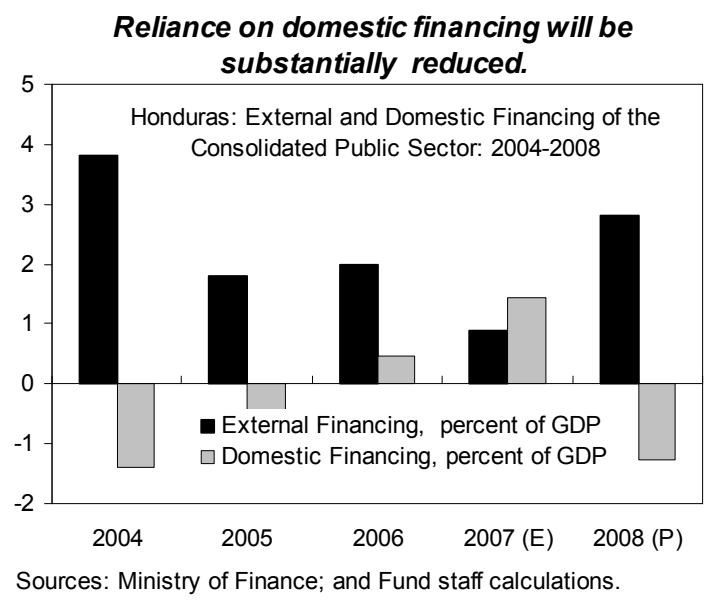
12 percent of GDP and is expected to remain below 14 percent in the medium-term-well below distress thresholds (50 percent of GDP) (Appendix II). Key sources of financing include:

- Petrocaribe. Concessional financing for US\$350 million in 2008-09 is expected (about 2.8 percent of 2007 GDP), with about US $\$ 80$ million earmarked in the 2008 budget to finance hydroelectric projects and upgrade transmission and distribution infrastructure. The authorities plan to earmark the rest for energy projects over 2009-12 and seek advice from the World Bank and IDB in the selection and monitoring of the projects. By investing in hydroelectric projects, the plan will help reduce fuel imports and the external current account deficit over the medium term. The creation of a trust fund at the central bank to hold the proceeds from Petrocaribe will help ensure that the resources are managed and recorded in a transparent manner and 
used for infrastructure only. Staff encouraged the authorities to resist pressures to use these funds for current spending.

- $\quad$ Proceeds of a cellular license sale. The 2008 budget earmarks these one-time proceeds (0.6 percent of GDP) for already identified infrastructure projects, mostly roads. Since these resources are not debt creating, there are no risks for fiscal sustainability.

\section{Containing Inflation and Safeguarding External Stability}

15. Supported by

fiscal policy, the

monetary program

for 2008 aims to

contain inflation while

reversing the declining

trend in international

reserves. Key priorities

are to keep inflation

within a range of 8

10 percent by

containing the second-

round effects of food

and energy price and

wage increases, while

reducing the growth of
Aided by fiscal policy, monetary policy is geared to achieve the reserve target while maintaining the stock of open market bills

\begin{tabular}{|c|c|c|c|c|c|}
\hline & \multirow{2}{*}{$\begin{array}{r}2007 \text { Prel. } \\
\text { Dec. }\end{array}$} & \multicolumn{4}{|c|}{2008 Program } \\
\hline & & Mar. & Jun. & Sep. & Dec. \\
\hline & \multicolumn{5}{|c|}{ (In millions of Lempiras) } \\
\hline & \multicolumn{5}{|c|}{ I. Central Bank } \\
\hline Net International Reserves & 46,727 & 46,728 & 49,480 & 50,553 & 53,079 \\
\hline (Millions of U.S.dollars) & 2,473 & 2,473 & 2,593 & 2,623 & 2,726 \\
\hline $\begin{array}{l}\text { Net Domestic Assets } \\
\text { of which: }\end{array}$ & $-30,364$ & $-31,078$ & $-34,320$ & $-36,036$ & $-34,241$ \\
\hline Credit to the public sector (net) & 4,748 & 6,941 & 3,672 & 1,539 & 2,046 \\
\hline Other depository institutions (net) & $-23,186$ & $-25,679$ & $-25,524$ & $-24,464$ & $-23,156$ \\
\hline o/w: Deposits in local currency & $-8,241$ & $-8,109$ & $-7,764$ & $-7,673$ & $-7,656$ \\
\hline o/w: Open market operations & $-9,064$ & $-9,855$ & $-8,257$ & $-7,193$ & $-5,445$ \\
\hline o/w: Obligatory investments & $-2,255$ & $-3,797$ & $-5,704$ & $-5,804$ & $-6,140$ \\
\hline Currency & 16,363 & 15,650 & 15,160 & 14,517 & 18,838 \\
\hline \multicolumn{6}{|l|}{ Memorandum: } \\
\hline Total stock of open market bills & 16,705 & 17,189 & 16,809 & 17,081 & 16,834 \\
\hline
\end{tabular}

Source: Central Bank of Honduras

bank credit to more sustainable levels. The program targets a build up of net international reserves of US\$253 million to stabilize nonmaquila import coverage at 4 months.

\section{Consistent with these goals, the central bank took some initial steps to tighten}

monetary policy. It raised the policy interest rate by 25 bps to 73 paercent in February and is implementing additional measures equivalent to 2 percentage points of reserve requirements in March through a combination of higher obligatory investments and the placement of open market bills (prior actions). At the same time, the central bank introduced changes to obligatory investments and reserve requirements to bring them in line with levels in neighboring countries (particularly for reserve requirements on foreign currency deposits) and to discourage consumption lending (MEFP \$6). In particular:

- Increase in obligatory investments. These will be raised gradually by 5 percentage points (from 4 to 9 percent of bank deposits), starting in March. Government bonds, which will be used to repay ENEE arrears to private generators, were made eligible to meet these investments to induce banks to hold this paper.

- $\quad$ Reduction in reserve requirements. These will be lowered gradually from 12 to 7 percent on Lempira deposits (and from 34 to 24 percent on U.S. dollar deposits), in 
monthly steps starting in March, for banks that increase their share of loans to priority sectors (which exclude consumer loans and retail).

\section{While staff understands the rationale for the recent changes in obligatory} investments and reserve requirements, it expressed several concerns. The team stressed that the reduction in reserve requirements could have an expansionary impact of up to 1 percent of GDP in 2008; the impact will be small initially, but could get bigger during the second half of the year as banks reconfigure their loan portfolios. Staff advised the authorities to implement uniform reserve requirements, avoid credit rules that could be circumvented, and encouraged them to allow market forces to play a greater role in determining interest rates on government bonds. The authorities argued that their policy of differentiated reserve requirements seeks to shift banks' credit to priority sectors. They also underscored their intention to mop up any excess liquidity from these measures and to reassess them in the first review of the program, adjusting them as necessary to ensure consistency with program objectives. They also noted that bank collusion and uncompetitive conditions made it necessary to use obligatory investments to avoid excessively high interest rates.

18. Exchange rate policy will be geared to support monetary policy, safeguard external competitiveness and protect the economy against shocks. While the real exchange rate appears to be near its long-run equilibrium, Honduras maintains high price and wage inflation relative to trading partners and remains vulnerable to changes in world oil and food prices, external demand, and workers' remittances. The authorities have started to satisfy only part of the bids at the foreign

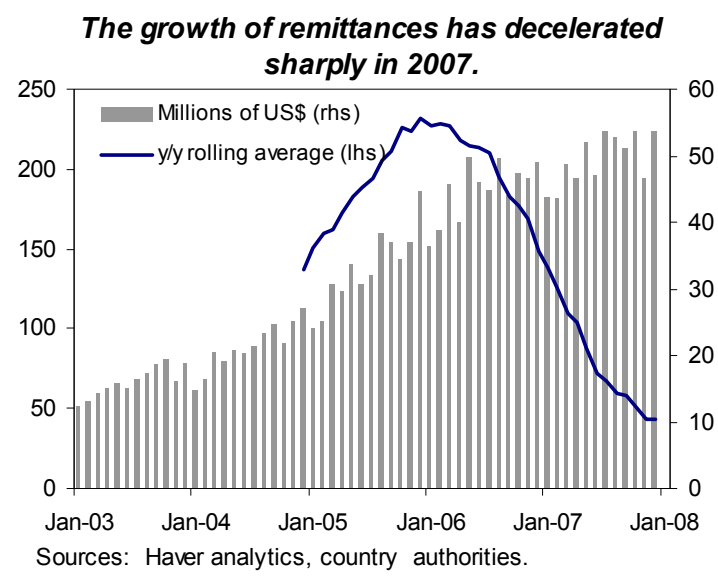
exchange auctions, allowing the exchange rate to move marginally away from the most appreciated edge of the band. The team encouraged the authorities to use this flexibility actively to protect external competitiveness and reserve targets were external developments to be more adverse than anticipated. Exchange rate management will be reexamined in the first program review based on a study of the options for the exchange rate system (MEFP 97 ).

\section{Prudential policy will encourage banks to internalize the risks associated with the} rapid expansion of bank credit, particularly for consumption. While the soundness of the banking system has improved considerably in recent years, the recent FSAP update noted that the entry of foreign banks and rapid credit expansion (mainly for consumption and commercial real estate) may put stress on the financial system. In this context, the issuance of regulations to tighten loan classification and provisioning is an important step. General provisions have been set for all loans, but with higher provisions for credit card debt and commercial loans with real estate collateral, which have been growing rapidly and are considered particularly risky. The authorities indicated that household mortgages were excluded to avoid restricting mortgage credit to low-income households. Swift implementation will be important to ensure 
that the regulations begin to take effect this year. The CNBS will also develop a timetable to introduce risk-based supervision, including the issuance of a regulation (MEFP \8) (structural performance criterion), and plans to use the recommendations of the recent FSAP update as a blue print to deepen banking reforms.

\section{Strengthening the Energy Sector}

\section{Reforming the electricity sector is essential to safeguard the public finances and} support growth. In coordination with the World Bank and the IADB, the strategy to ensure a sustainable energy policy includes putting the electricity company (ENEE) on a sound financial footing, improving its governance, reducing distribution losses and fraud, and reversing the persistent underinvestment in the sector (MEFP q9). The authorities named a new ENEE manager in early 2008 and have prepared an investment plan in consultation with the World Bank.

\section{Ensuring the electricity company is on a sound financial footing is of key}

macroeconomic importance. To achieve this goal, the program envisages a tariff structure that fully covers operational costs. According to the World Bank, this implies raising electricity tariffs by 26 percent over end-2007 levels at December 2007 bunker prices (US\$74 per barrel). In a decisive move, average tariffs were adjusted up by 15 percent in January and will be increased by a further 11 percent in April, when a new tariff structure comes into effect (structural performance criterion). The authorities intend to adjust tariffs periodically to passthrough any further increase in international fuel prices above their current level to domestic prices, in accordance with the current law, thus helping ensure that ENEE no longer falls into arrears with generators. Furthermore, with the congressional approval of the 2008 budget, all payment arrears of ENEE with generators will be cleared by end-June through the issuance of government bonds.

\section{Financing, Access and Program Modalities}

22. The SBA would help unlock financing needed to cover a gap in 2008. This takes into account the need to maintain reserve coverage, with a projected slowdown of import growth through monetary and fiscal tightening and an increase in FDI (particularly in the maquila and telecommunication sectors). The financing gap is estimated at about US\$76 million and is projected to be filled by World Bank and IADB budget-support loans and grants, and financing from other bilateral creditors. Swiftly unlocking external financing is important to avoid derailing 
the authorities' investment program. Honduras will continue to remain current on its external debt payment obligations. $^{2}$

\section{The proposed}

precautionary $S B A$, with low access and minimum risk of failure to repay the Fund, covers the macroeconomic program through end-

December 2008. Total access under the arrangement will be 30 percent of quota

(SDR 38.85 million), with the first drawing of 25 percent of quota in line with first credit tranche policies, and the remaining 5 percent divided evenly between three purchases after reviews. Honduras is current on its
The program would be financed by an increase in World Bank and IADB disbursements

\begin{tabular}{|c|c|c|c|c|c|}
\hline & \multicolumn{5}{|c|}{ Projections } \\
\hline & 2007 & 2008 & 2009 & 2010 & 2011 \\
\hline & \multicolumn{5}{|c|}{ (In U.S. dollars) } \\
\hline Current account & $-1,225$ & $-1,308$ & $-1,344$ & $-1,244$ & $-1,126$ \\
\hline Capital account & 1,158 & 28 & 22 & 33 & 36 \\
\hline Financial account & -42 & 1,443 & 1,541 & 1,438 & 1,443 \\
\hline Disbursements 1/ & 246 & 382 & 454 & 237 & 201 \\
\hline Amortization & $-1,273$ & -78 & -70 & -61 & -62 \\
\hline Other & 985 & 1,140 & 1,157 & 1,262 & 1,303 \\
\hline Overall balance & -136 & 164 & 220 & 227 & 354 \\
\hline Reserve assets & 109 & -253 & -279 & -289 & -376 \\
\hline Reserve liabilities & -7 & 0 & 0 & 2 & 0 \\
\hline Exceptional financing & 34 & 14 & 0 & 0 & 0 \\
\hline Financing gap & $\ldots$ & 76 & 59 & 60 & 22 \\
\hline World Bank & $\ldots$ & 34 & 0 & 0 & 0 \\
\hline IADB & $\ldots$ & 28 & 15 & 30 & 0 \\
\hline Bilaterals and other multilaterals & $\ldots$ & 15 & 14 & 0 & 0 \\
\hline IMF 2/ & $\ldots$ & 0 & 0 & 0 & 0 \\
\hline Unidentified financing & $\ldots$ & 0 & 30 & 30 & 22 \\
\hline \multicolumn{6}{|l|}{ Memorandum items: } \\
\hline MDRI from IDB & 1,128 & $\ldots$ & $\ldots$ & $\ldots$ & $\ldots$ \\
\hline Change in NIR (+ accumulation) & -102 & 253 & 279 & 287 & 376 \\
\hline
\end{tabular}

Source: Fund staff estimates.

$1 /$ Includes project-financed loans.

2/ Assumes no purchases under the SBA

payments toward the Fund and has no GRA purchases outstanding. Repurchase obligations under the proposed SBA will average 1.1 percent of projected gross reserves for 2010-2012.

\section{The program envisages three reviews, beginning at end-June 2008. Prior actions} include a tightening of monetary policy and congressional approval of the 2008 budget consistent with an overall deficit of 1.5 percent of GDP and in line with the current expenditure indicative targets, including the wage bill. Quantitative performance criteria and indicative targets will be measured on a cumulative basis from January 1 (MEFP, Table 1). Given the importance of prompt action to strengthen the electricity sector and reduce risks in the financial sector, structural conditionality focuses on implementing a new tariff structure that fully covers the operational costs of ENEE; eliminating arrears of ENEE to help reduce the exposure of the financial system to the energy sector; and issuing regulations on risk based supervision to encourage banks to internalize the risks associated with the rapid expansion of credit (MEFP, Table 2).

\footnotetext{
${ }^{2}$ Arrears with private creditors of US\$5 million were recorded when some creditors did not participate in the October 2000 IDA debt repurchase offer for lack of sufficient supporting documentation; no request for payments has been received since then. The existence of these arrears does not undermine program implementation.
} 


\section{V.STAFF APPRAISAL}

\section{During 2007, significant imbalances began to emerge in the Honduran economy.}

While growth remains robust, expansionary fiscal and monetary policies, in a context of a de facto fixed exchange rate, have led to rising inflation, a sharp increase in the external current account deficit, and a decline in international reserves. Bank credit has been expanding rapidly, fueling imports and posing risks to economic stability and financial health. In addition, weaknesses in the energy sector pose risks to the public finances, the financial system, and growth.

\section{Staff considers that a precautionary $S B A$ can play an important role in supporting} the authorities' program over the coming months. While a PRGF is better suited to address Honduras' structural challenges, a medium-term structural reform agenda that enjoys broad support from all sectors of society still needs to be finalized. In this context, a precautionary SBA is appropriate to promptly address economic imbalances and reinforce confidence in the authorities' economic program, thereby unlocking donor financing and serving as a bridge to a new PRGF later this year.

27. The authorities' program appropriately strengthens macroeconomic policies and the energy sector. Reducing aggregate demand pressures and reforming the energy sector will improve public finances and enhance growth prospects. Early actions to date have been generally encouraging, including submission to congress of a prudent 2008 budget, a decisive increase in electricity tariffs, and a tightening of monetary policy, accompanied by a turnaround, since early February, in the declining trend of international reserves.

28. Fiscal consolidation and the redirection of spending to priority sectors is at the core of the authorities' program. The program includes an underlying adjustment of 2 percent of GDP, which permits a reduction in the overall deficit and a substantial increase in public investment, reversing the trend in recent years. Debt ratios will remain below their indicative thresholds and resilient to shocks over the medium and long term. The pick up in public investment includes hydroelectric projects, supporting growth objectives and helping reduce fuel imports and the external current account deficit over the medium term. Conscious of the need to protect the poor, the authorities are improving the targeting of electricity and direct fuel subsidies. It will be important to strengthen further the targeting of these subsidies and to limit them to agreed ceilings in the context of rising oil prices.

\section{Staff welcomes the authorities' intention to stabilize and then reduce the public wage} bill as a percent of GDP. Honduras' public wage bill is high by regional standards and its sharp rise in recent years has contributed to crowd out anti-poverty spending and public investment and has added to inflationary pressures. Looking forward, it will be key to resist pressures for additional wage increases and develop a comprehensive wage policy for the public sector. 
30. In contrast to past years, the budget is expected to be more than financed by concessional external lending, allowing a marked reduction in net domestic financing and supporting monetary policy. To this end, the authorities intend to move swiftly to unlock external financing. Staff welcomes the plan to earmark for hydroelectric projects the resources obtained from Petrocaribe. The creation of a trust fund at the central bank will help ensure that these resources are managed and recorded transparently. Staff encourages the authorities to resist pressures to use these funds for current spending.

31. Monetary tightening is key to the program. Staff welcomes the authorities' actions to significantly tighten monetary policy ahead of the Board meeting and the steps taken on prudential policy to address the risks associated with the rapid expansion of bank credit. While staff understands the authorities' rationale for the recent changes in reserve requirements and obligatory investments, it is concerned that these could have an increasingly expansionary impact on liquidity and limited effectiveness in redirecting credit to priority sectors. The impact of these changes on liquidity should be monitored carefully, with excess liquidity promptly mopped up, as the authorities intend, and the measures adjusted as necessary at the time of the first review to ensure that the program targets are met.

\section{The authorities' actions to allow greater flexibility within the existing exchange rate} regime are welcomed. While the exchange rate appears to be in line with fundamentals, external conditions are deteriorating significantly and the economy remains highly vulnerable to oil prices and to a slowdown in the U.S. economy which would adversely affect remittances and exports. Staff encourages the authorities to stand ready to allow greater exchange rate flexibility, especially if external developments were to be more adverse than anticipated. The authorities have agreed to reexamine exchange rate management at the first review, in line with a study on the exchange rate system.

\section{The program will help ensure that the electricity company is on a sound financial} footing. Staff commends the authorities for their decisive increase in electricity tariffs and for their intention to adjust the new tariff periodically to pass-through any further increase in international fuel prices, thus helping avoid new arrears with generators. The expected clearance of all payment arrears with generators through the issuance of government bonds is also a key step. Staff encourages the authorities to continue working closely with the World Bank and the IADB to strengthen further the governance of the electricity company, reduce distribution losses and fraud, and reverse the persistent underinvestment in the sector.

\section{The proposed Stand-By Arrangement will provide an anchor for economic} policymaking and reinforce confidence, paving the way for an early move to a PRGF. Prior actions taken on the monetary side and the expected congressional approval of the budget are important, underscoring the authorities' ownership. Looking ahead, it will be key to resist pressures for expansionary policies in the run-up to primary elections scheduled for late 2008, improve implementation of the capital budget and adjust policies promptly were the deterioration in external conditions to be higher-than-anticipated. Given the structural challenges in Honduras, staff urges the authorities to finalize swiftly a medium-term plan with 
policies for poverty alleviation and growth that could be supported under the Poverty Reduction and Growth Facility before end-2008.

35. In light of these considerations, staff recommends approval of the authorities' request for a Stand-By Arrangement. 
Table 1. Honduras: Selected Economic Indicators

Population

Per capita income in U.S. dollars (2006)

Rank in UNDP Development Index (2007/08)

Unemployment rate (2007)

Underemployment rate (2007)

Net FDI (as percent of GDP, 2007)

I. Social Indicators

7.5 million Life expectancy at birth in years (2007)

2,100 Adult literacy (ages 15 and above, 2007) 80 percent

115 of 177 Percent of pop. below poverty line (2007) 64

$3.4 \quad$ Gini index 55

32.2 Oil imports (2006 actual) US $\$ 1.0$ billion

3.3 Main exports coffee, bananas, shrimp, and maquila

II. Economic Indicators

Prel. Prog. Proj.

$2004-2005$

$2008 \quad 2009$

(Annual percentage change, unless otherwise indicated)

National income and prices

GDP at constant prices

GDP deflator

Consumer prices (end of period, eop)

\author{
6.
}

6.5

6.1

6.3

6.3

7.0

$4.8 \quad 4.6$

9.2

7.3
7.7

4.8
5.3

8.9

$\begin{array}{ll}8.8 & 7.7\end{array}$

Exchange rate (eop, depreciation -)

Lempiras per U.S. dollar

Real effective rate

$\begin{array}{llll}-4.9 & -1.2 & 0.0 & 0.0\end{array}$

$\begin{array}{llll}-1.4 & 0.9 & 1.7 & 2.3\end{array}$

Money and credit

Net domestic assets $1 /$

Combined public sector credit

4.5
52.1

52.1
15.9

15.9
18.1

18.2

11.1

13.2
1.4
16.4
15.5
16.8
10.4

32.3

37.7

$-25.0$

32.1

16.1

Lending rate (eop, in percent)

$16.4 \quad 29.2$

29.2
22.5

$16.8 \quad 13.8$

13.4
8.1

(In percent of GDP)

Combined public sector

Noninterest revenue and grants

Noninterest expenditure

Primary balance

Net interest payments

22.7

Capital expenditure

\section{Overall balance}

External financing

Domestic financing

\section{Savings and investment}

Fixed capital formation

Gross national savings
24.8

$-2.1$

0.3

\section{6}

24.1

22.7

24.8

22.7

25.6

$-2.8$

$-1.5 \quad-2.1$

$-0.4$

$-0.5$

\section{6}

2.5

2.8

1.9

\section{5}

$-2.4$

3.8

$-1.4$

$-1.4$

4.8

4.8

$-2.3$

$-1.7$

1.8

2.0

0.9

1.5

23.8

26.1

$-2.3$

$-0.7$

2.9

6.5

$-1.5$

$\begin{array}{rr}-1.5 & 3.0\end{array}$

$-1.3 \quad-1.5$

$\begin{array}{llll}27.1 & 24.9 & 27.7 & 30.4\end{array}$

32.7

23.2
$-1.5$

32.3

23.8

$-2$

$-0.6$

3.3

$-1.5$

(In millions of U.S. dollars, unless otherwise indicated)

\title{
Balance of payments
}

Gross international reserves

(in months of imports) 2/

Change in net international reserves (increase -) 1/

External current account balance (percent of GDP) (excluding official transfers)

Exports, f.o.b. (annual percentage change) 3/

Imports, f.o.b. (annual percentage change) 3/

Public sector debt (in percent of GDP) 4/

Public sector external debt (in percent of GDP) 4/

Public sector external debt service (in percent

of exports of goods and services) $5 /$

4.8

$-516.2$

$-7.7$

$-9.8$

20.8

22.1

66.6

57.9

3.3
2,526

4.8

$-359.9$

$-3.0$

$-4.6$

11.3

12.3

52.8

42.9

3.7
2,824

4.5

$-448.6$

$-4.7$

$-6.5$

2.9

11.8

35.4

28.3

2,733

3.9

101.9

$-10.0$

$-11.0$

7.7

16.9

23.7

16.6

$2.6 \quad 2.0$ $\begin{array}{rr}2,992 & 3,294 \\ 3.9 & 4.0\end{array}$

$-253.3-278.7$

$\begin{array}{ll}-9.5 & -9.0\end{array}$

$\begin{array}{ll}-10.7 & -10.2\end{array}$

$\begin{array}{ll}6.7 & 7.4\end{array}$

$10.6 \quad 8.0$

$22.5 \quad 22.1$

$17.6 \quad 19.2$

\begin{tabular}{ll}
$1.6 \quad 1.3$ \\
\hline
\end{tabular}

Sources: Central Bank of Honduras; Ministry of Finance; and Fund staff estimates.

$1 /$ Includes adjustments made for NIR and NDA due to Fund MDRI debt relief granted in January 2006 (\$155 million). 2/Refers to the following year's imports of nonmaquila goods and nonfactor services.

$3 /$ Goods only.

4/Includes medium and long-term public and publicly guaranteed external debt.

5/Debt service paid. 
Table 2. Honduras: Operations of the Central Government

\begin{tabular}{|c|c|c|c|c|c|}
\hline & 2005 & 2006 & $\begin{array}{l}\text { Prel. } \\
2007 \\
\end{array}$ & $\begin{array}{l}\text { Prog. } \\
2008 \\
\end{array}$ & $\begin{array}{l}\text { Proj. } \\
2009 \\
\end{array}$ \\
\hline Total revenue and grants & 17.6 & 18.2 & 18.6 & 19.8 & 19.7 \\
\hline Current revenue & 16.4 & 16.7 & 17.4 & 18.1 & 18.1 \\
\hline Tax revenue & 14.5 & 15.4 & 16.2 & 16.4 & 16.7 \\
\hline Nontax revenue & 1.0 & 1.0 & 0.9 & 1.3 & 1.2 \\
\hline Of which: Telecommunications law & 0.0 & 0.0 & 0.0 & 0.5 & 0.0 \\
\hline Transfers & 0.8 & 0.4 & 0.3 & 0.3 & 0.3 \\
\hline Capital revenue & 0.1 & 0.0 & 0.0 & 0.0 & 0.1 \\
\hline Grants & 1.1 & 1.5 & 1.2 & 1.7 & 1.5 \\
\hline Of which: MCC & 0.0 & 0.4 & 0.1 & 0.4 & 0.3 \\
\hline Total expenditure & 19.9 & 19.3 & 20.7 & 21.6 & 21.3 \\
\hline Current expenditure & 15.6 & 16.1 & 16.9 & 16.4 & 15.9 \\
\hline Wages and salaries & 8.2 & 8.3 & 9.2 & 9.2 & 9.1 \\
\hline Goods and services & 2.4 & 2.6 & 2.8 & 2.6 & 2.3 \\
\hline Transfers & 3.7 & 3.6 & 3.8 & 3.4 & 3.3 \\
\hline Of which: Electricity subsidies 1/ & $\ldots$ & 0.5 & 0.4 & 0.3 & 0.2 \\
\hline Of which: Direct fuel subsidies & $\ldots$ & 0.3 & 0.4 & 0.4 & 0.3 \\
\hline Of which: Urban transport subsidies 2/ & $\ldots$ & 0.1 & 0.1 & 0.1 & 0.1 \\
\hline Interest payments & 1.3 & 1.0 & 0.7 & 0.6 & 0.7 \\
\hline External & 0.9 & 0.7 & 0.3 & 0.3 & 0.3 \\
\hline Domestic & 0.4 & 0.3 & 0.3 & 0.3 & 0.4 \\
\hline Other current expenditure & 0.2 & 0.6 & 0.6 & 0.5 & 0.5 \\
\hline Capital expenditure & 4.4 & 3.4 & 3.8 & 5.3 & 5.5 \\
\hline Net lending & -0.1 & -0.2 & 0.0 & 0.0 & 0.0 \\
\hline Overall balance & -2.3 & -1.1 & -2.1 & -1.8 & -1.6 \\
\hline Financing & 2.3 & 1.1 & 2.1 & 1.8 & 1.6 \\
\hline External financing & 1.9 & 1.2 & 1.0 & 2.9 & 3.1 \\
\hline Disbursements & 2.9 & 1.8 & 1.8 & 3.2 & 3.4 \\
\hline Amortization & -2.7 & -1.2 & -1.0 & -0.4 & -0.4 \\
\hline Exceptional financing & 1.7 & 0.7 & 0.3 & 0.1 & 0.1 \\
\hline Change in arrears & 0.0 & 0.0 & 0.0 & 0.0 & 0.0 \\
\hline Domestic financing & 0.5 & 0.1 & 1.1 & -1.0 & -1.5 \\
\hline Financial system & 0.6 & -1.3 & -0.5 & -0.8 & -1.5 \\
\hline Central bank & 0.8 & -1.2 & -0.4 & -0.7 & -1.5 \\
\hline Rest of the financial system (incl. Pension funds) & -0.1 & 0.0 & -0.1 & -0.2 & 0.1 \\
\hline Bonds outside the financial system & 0.1 & 0.1 & 0.0 & 0.0 & 0.0 \\
\hline Floating debt & -0.3 & 1.2 & 1.6 & -1.5 & 0.0 \\
\hline Privatization/deposits abroad 3/ & 0.0 & 0.1 & 0.0 & 0.6 & 0.0 \\
\hline Statistical discrepancy 4/ & 0.0 & -0.2 & 0.0 & -0.1 & 0.0 \\
\hline \multicolumn{6}{|l|}{ Memorandum items: } \\
\hline Poverty spending (ERP) & 7.7 & 7.0 & 6.9 & 7.0 & 7.1 \\
\hline Of which: wages and salaries & 2.7 & 2.9 & 3.8 & 3.0 & 3.2 \\
\hline Of which: poverty spending net of wages & 4.9 & 4.1 & 3.1 & 4.0 & 4.0 \\
\hline Current primary spending & 14.3 & 15.1 & 16.3 & 15.8 & 15.2 \\
\hline Nominal GDP (in millions of Lempiras) & 183,748 & 204,685 & 232,817 & 265,530 & 299,198 \\
\hline
\end{tabular}

Sources: Honduran authorities; and Fund staff estimates.

$1 /$ Includes direct electricity subsidy and Bonochenta.

2 Includes urban transport subsidy and public transport fare stabilization subsidy.

$3 /$ Includes proceeds of the sale of a cellular band license in 2008.

4/In 2008 discrepancies are due to methodological differences between the Ministry of Finance and the Central Bank. 
Table 2a. Honduras: Operations of the Central Government - Quarterly

(in millions of lempiras)

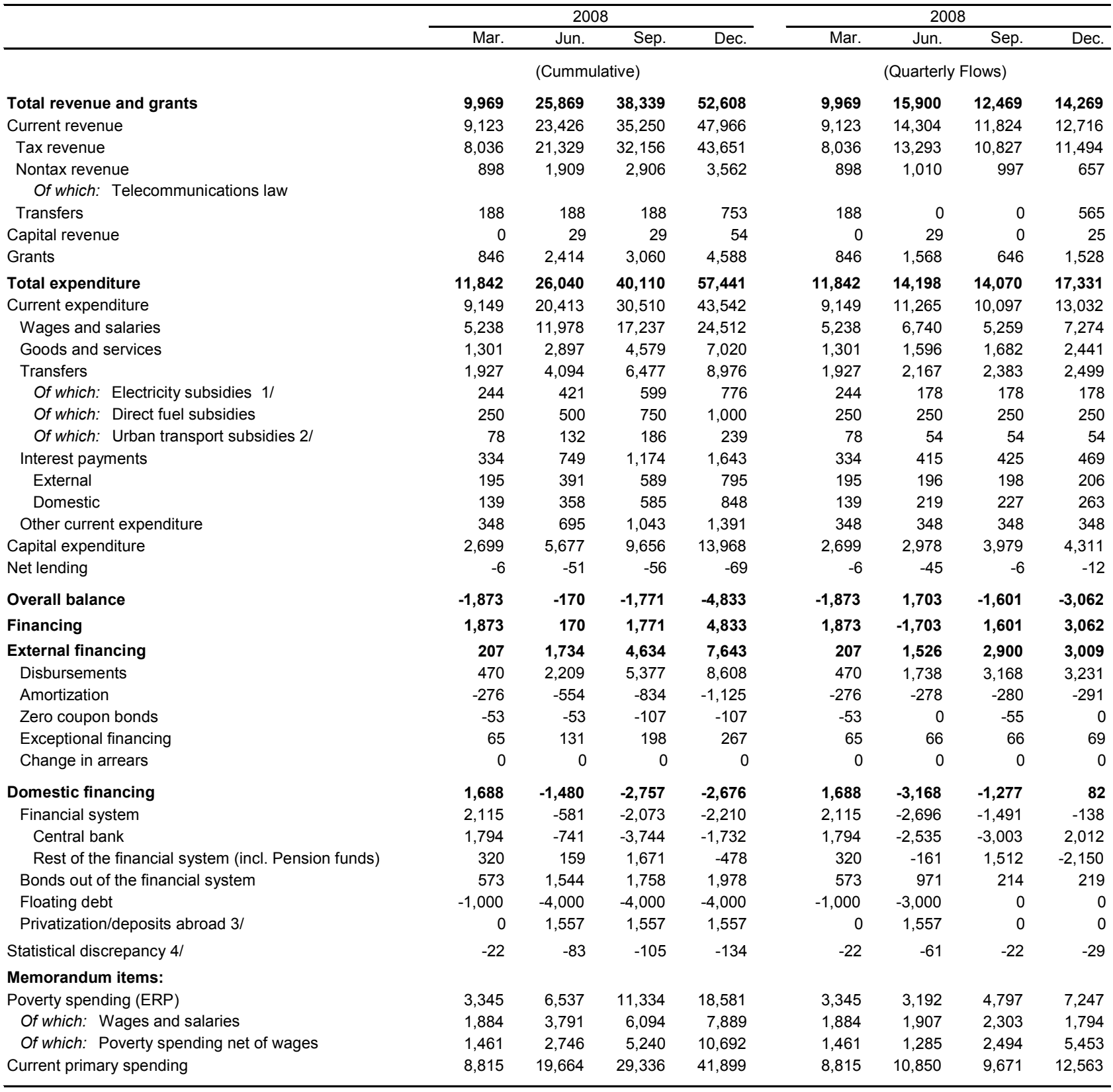

Sources: Honduran authorities; and Fund staff estimates.

$1 /$ Includes direct electricity subsidy and Bonochenta.

2/Includes urban transport subsidy and public transport fare stabilization subsidy.

$3 /$ Includes proceeds of the sale of a cellular band license in 2008 .

4/In 2008 discrepancies are due to methodological differences between the Ministry of Finance and the Central Bank. 
Table 3. Honduras: Operations of the Combined Public Sector

\begin{tabular}{|c|c|c|c|c|c|}
\hline & 2005 & 2006 & $\begin{array}{l}\text { Prel. } \\
2007 \\
\end{array}$ & $\begin{array}{l}\text { Prog. } \\
2008 \\
\end{array}$ & $\begin{array}{l}\text { Proj. } \\
2009 \\
\end{array}$ \\
\hline Total revenue and grants & 24.2 & 24.3 & 24.1 & 25.2 & 25.2 \\
\hline Current revenue & 22.8 & 22.8 & 22.6 & 23.2 & 23.3 \\
\hline Tax revenue & 15.2 & 15.6 & 16.7 & 16.8 & 17.0 \\
\hline Nontax revenue & 4.1 & 4.5 & 4.1 & 4.5 & 4.3 \\
\hline Interest earnings & 1.6 & 1.6 & 1.4 & 1.4 & 1.4 \\
\hline Operating balance of public enterprises & 2.0 & 1.2 & 0.4 & 0.5 & 0.7 \\
\hline Capital revenue & 0.3 & 0.3 & 0.3 & 0.3 & 0.3 \\
\hline Grants & 1.1 & 1.1 & 1.2 & 1.7 & 1.5 \\
\hline Of which: MCC & 0.0 & 0.0 & 0.1 & 0.4 & 0.3 \\
\hline Total expenditure & 25.6 & 26.0 & 26.5 & 26.8 & 26.7 \\
\hline Current expenditure & 20.3 & 20.0 & 20.7 & 20.3 & 20.0 \\
\hline Wages and salaries & 10.6 & 10.8 & 11.7 & 11.4 & 11.5 \\
\hline Goods and services & 3.4 & 3.5 & 3.9 & 3.8 & 3.4 \\
\hline Transfers & 2.6 & 3.5 & 3.5 & 3.1 & 2.8 \\
\hline Operating losses of the central bank & 0.7 & 0.5 & 0.2 & 0.6 & 0.7 \\
\hline Interest payments & 1.5 & 1.2 & 0.9 & 0.7 & 0.7 \\
\hline External & 0.9 & 0.7 & 0.4 & 0.3 & 0.3 \\
\hline Domestic & 0.6 & 0.5 & 0.5 & 0.4 & 0.4 \\
\hline Other & 1.6 & 0.6 & 0.5 & 0.6 & 0.9 \\
\hline Capital expenditure & 5.1 & 4.8 & 4.8 & 6.5 & 6.7 \\
\hline Of which: ENEE & 0.1 & 0.3 & 0.4 & 0.6 & 0.5 \\
\hline Of which: Hondutel & 0.3 & 0.4 & 0.4 & 0.5 & 0.4 \\
\hline Net lending & 0.2 & 1.2 & 0.9 & 0.0 & 0.0 \\
\hline Overall balance & -1.4 & -1.7 & -2.3 & -1.5 & -1.5 \\
\hline Financing & 1.4 & 1.7 & 2.3 & 1.5 & 1.5 \\
\hline External & 1.8 & 2.0 & 0.9 & 2.9 & 3.0 \\
\hline Disbursements & 3.0 & 1.8 & 1.8 & 3.3 & 3.4 \\
\hline Amortization & -2.8 & -0.5 & -1.1 & -0.5 & -0.5 \\
\hline Exceptional financing & 1.7 & 0.7 & 0.3 & 0.1 & 0.1 \\
\hline Change in arrears & 0.0 & 0.0 & 0.0 & 0.0 & 0.0 \\
\hline Domestic financing & -0.6 & 0.5 & 1.5 & -1.3 & -1.5 \\
\hline Financial system & -0.1 & -0.1 & -0.4 & -0.5 & -1.5 \\
\hline Central bank & 0.3 & -0.2 & -0.3 & -1.2 & -1.6 \\
\hline Net credit to the NFPS & -0.4 & -0.6 & -0.5 & -1.8 & -2.3 \\
\hline Operating balance of the central bank & 0.7 & 0.5 & 0.2 & 0.6 & 0.7 \\
\hline Rest of the financial system & -0.4 & 0.1 & -0.1 & 0.6 & 0.1 \\
\hline Bonds outside the financial system & 0.2 & 0.2 & 0.0 & 0.0 & 0.0 \\
\hline Floating debt & -0.3 & 0.2 & 1.9 & -1.4 & 0.0 \\
\hline Privatization/deposits abroad $1 /$ & -0.4 & 0.3 & 0.0 & 0.6 & 0.0 \\
\hline Statistical discrepancy 2/ & 0.2 & -0.7 & 0.0 & 0.0 & 0.0 \\
\hline \multicolumn{6}{|l|}{ Memorandum items: } \\
\hline Arrears of ENEE with private generators, eop stock & $\ldots$ & $\ldots$ & 1.6 & 0.0 & 0.0 \\
\hline Nominal GDP (in millions of Lempiras) & 183,748 & 204,685 & 232,817 & 265,530 & 299,198 \\
\hline
\end{tabular}

Sources: Honduran authorities; and Fund staff estimates.

$1 /$ Includes proceeds of the sale of a cellular band license in 2008.

2/In 2008 discrepancies are due to methodological differences between the Ministry of Finance and the Central Bank. 
Table 3a. Honduras: Operations of the Combined Public Sector - Quarterly

(in millions of lempiras)

\begin{tabular}{|c|c|c|c|c|c|c|c|c|}
\hline & \multicolumn{4}{|c|}{2008} & \multicolumn{4}{|c|}{2008} \\
\hline & Mar. & Jun. & Sep. & Dec. & Mar. & Jun. & Sep. & Dec. \\
\hline & \multicolumn{4}{|c|}{ (Cummulative) } & \multicolumn{4}{|c|}{ (Quarterly Flows) } \\
\hline Total revenue and grants & 13,150 & 32,238 & 48,416 & 66,994 & 13,150 & 19,089 & 16,178 & 18,578 \\
\hline Current revenue & 12,126 & 29,440 & 44,796 & 61,643 & 12,126 & 17,314 & 15,356 & 16,847 \\
\hline Tax revenue & 8,263 & 21,783 & 32,837 & 44,559 & 8,263 & 13,520 & 11,054 & 11,721 \\
\hline Nontax revenue & 2,999 & 5,921 & 8,830 & 11,964 & 2,999 & 2,922 & 2,910 & 3,134 \\
\hline Interest earnings & 929 & 1,859 & 2,788 & 3,717 & 929 & 929 & 929 & 929 \\
\hline Operating balance of public enterprises & -65 & -122 & 341 & 1,404 & -65 & -57 & 463 & 1,063 \\
\hline Capital revenue & 175 & 379 & 553 & 753 & 175 & 204 & 175 & 200 \\
\hline Grants & 849 & 2,419 & 3,067 & 4,598 & 849 & 1,570 & 648 & 1,531 \\
\hline Total expenditure & 15,210 & 32,722 & 50,313 & 71,094 & 15,210 & 17,512 & 17,591 & 20,781 \\
\hline Current expenditure & 11,637 & 25,310 & 38,194 & 53,919 & 11,637 & 13,673 & 12,884 & 15,725 \\
\hline Wages and salaries & 6,699 & 14,899 & 21,556 & 30,354 & 6,699 & 8,200 & 6,657 & 8,798 \\
\hline Goods and services & 2,098 & 4,441 & 6,843 & 10,058 & 2,098 & 2,343 & 2,402 & 3,215 \\
\hline Transfers & 1,902 & 3,835 & 6,219 & 8,328 & 1,902 & 1,933 & 2,384 & 2,109 \\
\hline Operating losses of the central bank & 306 & 541 & 1,166 & 1,699 & 306 & 235 & 625 & 533 \\
\hline Interest payments & 372 & 825 & 1,288 & 1,795 & 372 & 453 & 463 & 507 \\
\hline External & 203 & 408 & 615 & 829 & 203 & 205 & 207 & 214 \\
\hline Domestic & 169 & 417 & 673 & 966 & 169 & 248 & 256 & 293 \\
\hline Other & 259 & 768 & 1,122 & 1,686 & 259 & 509 & 354 & 564 \\
\hline Capital expenditure & 3,577 & 7,466 & 12,157 & 17,223 & 3,577 & 3,889 & 4,691 & 5,065 \\
\hline Of which: ENEE & 100 & 613 & 1,126 & 1,639 & 100 & 513 & 513 & 513 \\
\hline Of which: Hondutel & 323 & 646 & 968 & 1,291 & 323 & 323 & 323 & 323 \\
\hline Net lending & -4 & -54 & -39 & -48 & -4 & -50 & 15 & -10 \\
\hline Overall balance & $-2,060$ & -484 & $-1,897$ & $-4,099$ & $-2,060$ & 1,576 & $-1,413$ & $-2,203$ \\
\hline Financing & 2,060 & 484 & 1,897 & 4,099 & 2,060 & $-1,576$ & 1,413 & 2,203 \\
\hline External & 206 & 1,731 & 4,629 & 7,637 & 206 & 1,525 & 2,898 & 3,007 \\
\hline Disbursements & 522 & 2,311 & 5,531 & 8,816 & 522 & 1,789 & 3,220 & 3,285 \\
\hline Amortization & -328 & -659 & -993 & $-1,340$ & -328 & -331 & -334 & -347 \\
\hline Zero coupon bonds & -53 & -53 & -107 & -107 & -53 & 0 & -55 & 0 \\
\hline Exceptional financing & 65 & 131 & 198 & 267 & 65 & 66 & 66 & 69 \\
\hline Change in arrears & 0 & 0 & 0 & 0 & 0 & 0 & 0 & 0 \\
\hline Domestic financing & 1,866 & $-1,090$ & $-2,452$ & $-3,481$ & 1,866 & $-2,956$ & $-1,363$ & $-1,029$ \\
\hline Financial system & 2,866 & 1,006 & -347 & $-1,372$ & 2,866 & $-1,860$ & $-1,353$ & $-1,025$ \\
\hline Central bank & 2,193 & $-1,464$ & $-3,597$ & $-3,090$ & 2,193 & $-3,657$ & $-2,133$ & 507 \\
\hline Net credit to the NFPS & 1,887 & $-2,005$ & $-4,763$ & $-4,789$ & 1,887 & $-3,892$ & $-2,758$ & -26 \\
\hline Operating balance of the central bank & 306 & 541 & 1,166 & 1,699 & 306 & 235 & 625 & 533 \\
\hline Rest of the financial system & 673 & 2,470 & 3,250 & 1,718 & 673 & 1,797 & 780 & $-1,532$ \\
\hline Bonds out of the financial system & 0 & -2 & -11 & -15 & 0 & -2 & -9 & -4 \\
\hline Floating debt & $-1,000$ & $-3,651$ & $-3,651$ & $-3,651$ & $-1,000$ & $-2,651$ & 0 & 0 \\
\hline Privatization/deposits abroad 1/ & 0 & 1,557 & 1,557 & 1,557 & 0 & 1,557 & 0 & 0 \\
\hline Statistical discrepancy $2 /$ & -12 & -157 & -280 & -56 & -12 & -145 & -123 & 224 \\
\hline Memorandum item: & & & & & & & & \\
\hline Arrears of ENEE with private generators & 2,651 & 0 & 0 & 0 & 2,651 & $-2,651$ & 0 & 0 \\
\hline
\end{tabular}

Sources: Honduran authorities; and Fund staff estimates.

$1 /$ Includes proceeds of the sale of a cellular band license in 2008.

2/In 2008 discrepancies are due to methodological differences between the Ministry of Finance and the Central Bank. 
Table 4. Honduras: Summary Accounts of the Banking System

\begin{tabular}{|c|c|c|c|c|c|c|}
\hline & 2004 & 2005 & 2006 & $\begin{array}{l}\text { Prel. } \\
2007\end{array}$ & $\begin{array}{l}\text { Prog. } \\
2008\end{array}$ & $\begin{array}{l}\text { Proj. } \\
2009\end{array}$ \\
\hline & \multicolumn{6}{|c|}{ (In millions of Lempiras) } \\
\hline & \multicolumn{6}{|c|}{ I. Central Bank } \\
\hline Net International Reserves & 32,911 & 40,175 & 48,651 & 46,727 & 53,079 & 60,814 \\
\hline (In millions US\$) & 1,766 & 2,126 & 2,575 & 2,473 & 2,726 & 3,005 \\
\hline (Accumulation over the year) & 516 & 360 & 449 & -102 & 253 & 279 \\
\hline Net Domestic Assets & $-23,532$ & $-29,062$ & $-35,058$ & $-30,364$ & $-34,241$ & $-39,151$ \\
\hline Credit to the public sector (net) & 2,851 & 4,547 & 1,764 & 4,748 & 2,046 & 3,052 \\
\hline Non-financial public sector & $-1,868$ & & $-5,184$ & $-2,141$ & $-6,541$ & $-6,050$ \\
\hline Central government & $-1,264$ & -489 & $-4,415$ & $-1,468$ & $-6,184$ & $-5,670$ \\
\hline Public non-financial corporations & -544 & -903 & -648 & -550 & -294 & -317 \\
\hline Local governments & -60 & -68 & -120 & -123 & -63 & -63 \\
\hline Operating losses of the $\mathrm{BCH}$ & 4,719 & 6,008 & 6,947 & 6,888 & 8,587 & 9,102 \\
\hline Other depository institutions (net) & $-14,777$ & $-20,894$ & $-23,260$ & $-23,186$ & $-23,156$ & $-27,089$ \\
\hline Deposits in local currency & $-4,660$ & $-5,861$ & $-6,476$ & $-8,241$ & $-7,656$ & $-10,801$ \\
\hline Deposits in foreign currency & $-2,680$ & $-2,858$ & $-3,205$ & $-3,619$ & $-4,183$ & $-4,608$ \\
\hline Letras $\mathrm{BCH}$ & $-5,314$ & $-11,504$ & $-12,807$ & $-9,064$ & $-5,445$ & $-11,957$ \\
\hline Standing facility & -5 & -358 & -773 & -7 & -21 & -13 \\
\hline Obligatory investments & -851 & 0 & 0 & $-2,255$ & $-6,140$ & 0 \\
\hline Other financial institutions & $-2,308$ & $-2,615$ & $-3,528$ & $-1,930$ & $-1,276$ & -634 \\
\hline Nonfinancial private sector & $-2,030$ & $-2,282$ & $-1,851$ & $-1,047$ & -651 & -658 \\
\hline Medium and long-term net foreign liabilities & 257 & 657 & 825 & 699 & 916 & 953 \\
\hline Other items net $1 /$ & $-7,526$ & $-8,475$ & $-9,007$ & $-9,648$ & $-12,119$ & $-14,774$ \\
\hline \multirow[t]{2}{*}{ Currency } & 9,379 & 11,113 & 13,593 & 16,363 & 18,838 & 21,664 \\
\hline & \multicolumn{6}{|c|}{ II. Financial System } \\
\hline Net Foreign Assets & 39,075 & 46,267 & 52,408 & 48,851 & 52,948 & 60,701 \\
\hline (In millions of US\$) & 2,097 & 2,449 & 2,774 & 2,585 & 2,721 & 2,999 \\
\hline Net Domestic Assets & 40,156 & 45,475 & 60,145 & 82,791 & 99,845 & 111,813 \\
\hline Credit to the combined public sector & $-2,575$ & $-2,610$ & $-5,936$ & $-4,451$ & $-5,768$ & $-7,385$ \\
\hline Central government & $-2,896$ & $-3,102$ & $-7,756$ & $-7,261$ & $-9,471$ & $-9,471$ \\
\hline Other nonfinancial public sector & -142 & -274 & 300 & 907 & 1,287 & -441 \\
\hline Local governments & 464 & 766 & 1,521 & 1,903 & 2,416 & 2,528 \\
\hline Credit to the private sector & 60,089 & 69,964 & 90,426 & 119,460 & 141,202 & 159,810 \\
\hline Local currency & 42,476 & 49,685 & 63,714 & 89,465 & 105,747 & 119,683 \\
\hline Foreign currency & 17,614 & 20,279 & 26,712 & 29,995 & 35,455 & 40,127 \\
\hline Medium and long-term foreign liabilities & $-7,157$ & $-9,633$ & $-12,232$ & $-14,868$ & $-17,196$ & $-19,888$ \\
\hline Other items net & $-10,203$ & $-12,246$ & $-12,113$ & $-17,350$ & $-18,392$ & $-20,724$ \\
\hline \multirow[t]{2}{*}{ Broad money (M4) } & 79,231 & 91,741 & 112,553 & 131,641 & 152,794 & 172,514 \\
\hline & \multicolumn{6}{|c|}{ (Rate of Growth-12 month) } \\
\hline Currency issue & 16.4 & 18.5 & 22.3 & 20.4 & 15.1 & 15.0 \\
\hline Currency in circulation & 18.5 & 17.3 & 17.3 & 23.2 & 16.4 & 15.0 \\
\hline Broad money & 18.1 & 15.5 & 22.5 & 16.1 & 16.1 & 12.9 \\
\hline Credit to the private sector & 15.9 & 16.4 & 29.2 & 32.1 & 18.2 & 13.2 \\
\hline M1 & 9.6 & 15.7 & 22.2 & 17.9 & 14.5 & 13.7 \\
\hline \multirow{2}{*}{\multicolumn{7}{|c|}{ (End of period stock as percentage of GDP) }} \\
\hline & & & & & & \\
\hline Currency in circulation & 4.7 & 4.8 & 5.1 & 5.5 & 5.6 & 5.8 \\
\hline Broad money & 49.1 & 49.9 & 54.9 & 56.5 & 57.2 & 56.6 \\
\hline Credit to the private sector & 37.2 & 38.1 & 44.1 & 51.3 & 53.2 & 53.4 \\
\hline Stock of Letras BCH & 10.4 & 13.1 & 12.2 & 7.2 & 5.5 & 6.9 \\
\hline (In millions of lempiras) & 16,930 & 24,313 & 24,896 & 16,705 & 16,835 & 23,347 \\
\hline Annual operating losses of the $\mathrm{BCH}$ & 0.9 & 0.7 & 0.5 & 0.0 & 0.6 & 0.2 \\
\hline (In millions of Lempiras) & $1,465.0$ & $1,288.7$ & 939.5 & -58.9 & $1,698.8$ & 514.6 \\
\hline
\end{tabular}

Sources: Central Bank of Honduras; and Fund staff estimates.

$1 /$ Includes the revaluation account reflecting changes in the value of assets due to exchange rate fluctuations. 
Table 4a. Honduras: Summary Accounts of the Banking System - Quarterly

\begin{tabular}{|c|c|c|c|c|c|c|}
\hline & \multirow{3}{*}{$\begin{array}{l}\text { Prel. } \\
2007 \\
\text { Dec. }\end{array}$} & \multicolumn{4}{|c|}{ Program } & \multirow{3}{*}{$\begin{array}{r}\text { Projection } \\
2009 \\
\text { Dec. }\end{array}$} \\
\hline & & \multicolumn{4}{|c|}{2008} & \\
\hline & & Mar. & Jun. & Sep. & $\overline{\text { Dec. }}$ & \\
\hline & & \multicolumn{4}{|c|}{ (In millions of Lempiras) } & \\
\hline & \multicolumn{5}{|c|}{ I. Central Bank } & \\
\hline Net International Reserves & 46,727 & 46,728 & 49,480 & 50,553 & 53,079 & 60,814 \\
\hline (Millions US\$) & 2,473 & 2,473 & 2,593 & 2,623 & 2,726 & 3,005 \\
\hline (accumulation over the year) & -102 & 0 & 120 & 150 & 253 & \\
\hline Net Domestic Assets & $-30,364$ & $-31,078$ & $-34,320$ & $-36,036$ & $-34,241$ & $-39,151$ \\
\hline Credit to the Public Sector (net) & 4,748 & 6,941 & 3,672 & 1,539 & 2,046 & 3,052 \\
\hline Non-financial public sector & $-2,141$ & -254 & $-3,758$ & $-6,515$ & $-6,541$ & $-6,050$ \\
\hline Central Government & $-1,468$ & 515 & $-3,498$ & $-5,937$ & $-6,184$ & $-5,670$ \\
\hline Public non-financial corporations & -550 & -622 & -165 & -437 & -294 & -317 \\
\hline Local Governments & -123 & -146 & -94 & -142 & -63 & -63 \\
\hline Operating Losses of the $\mathrm{BCH}$ & 6,888 & 7,194 & 7,429 & 8,054 & 8,587 & 9,102 \\
\hline Other Depository Institutions (net) & $-23,186$ & $-25,679$ & $-25,524$ & $-24,464$ & $-23,156$ & $-26,673$ \\
\hline Deposits in local currency & $-8,241$ & $-8,109$ & $-7,764$ & $-7,673$ & $-7,656$ & $-10,801$ \\
\hline Deposits in foreign currency & $-3,619$ & $-3,763$ & $-3,910$ & $-3,871$ & $-4,183$ & $-4,608$ \\
\hline Letras $\mathrm{BCH}$ & $-9,064$ & $-9,855$ & $-8,257$ & $-7,193$ & $-5,445$ & $-11,541$ \\
\hline Standing Facility & -7 & -449 & -228 & -485 & -21 & -13 \\
\hline Obligatory investments & $-2,255$ & $-3,797$ & $-5,704$ & $-5,804$ & $-6,140$ & 0 \\
\hline Other financial institutions & $-1,930$ & $-2,040$ & $-1,961$ & $-1,565$ & $-1,276$ & $-1,051$ \\
\hline Non-financial private sector & $-1,047$ & $-1,065$ & -871 & -808 & -651 & -658 \\
\hline Medium- and long-term net foreign liabilities & 699 & 738 & 937 & 752 & 916 & 953 \\
\hline Other items net & $-9,648$ & $-9,971$ & $-10,572$ & $-11,489$ & $-12,119$ & $-14,774$ \\
\hline \multirow[t]{2}{*}{ Currency } & 16,363 & 15,650 & 15,160 & 14,517 & 18,838 & 21,664 \\
\hline & \multicolumn{5}{|c|}{ II. Financial Systems } & \\
\hline Net Foreign Assets & 48,851 & 47,085 & 48,522 & 45,639 & 52,948 & 60,701 \\
\hline (in millions of U.S. dollars) & 2,585 & 2,492 & 2,543 & 2,368 & 2,721 & 2,999 \\
\hline Net Domestic Assets & 82,791 & 89,276 & 93,518 & 95,028 & 99,845 & 111,813 \\
\hline Credit to the combined public sector & $-4,451$ & $-1,529$ & $-3,389$ & $-4,743$ & $-5,768$ & $-7,385$ \\
\hline Central government & $-7,261$ & $-5,147$ & $-7,843$ & $-9,334$ & $-9,471$ & $-9,471$ \\
\hline Other non-financial public sector & 907 & 1,512 & 1,437 & 1,362 & 1,287 & -441 \\
\hline Local governments & 1,903 & 2,106 & 3,016 & 3,229 & 2,416 & 2,528 \\
\hline Credit to the private sector & 119,460 & 124,719 & 129,744 & 133,805 & 141,202 & 159,810 \\
\hline Local currency & 89,465 & 93,403 & 97,166 & 100,207 & 105,747 & 119,683 \\
\hline Foreign currency & 29,995 & 31,316 & 32,577 & 33,597 & 35,455 & 40,127 \\
\hline Medium and long-term foreign liabilities & $-14,868$ & $-15,662$ & $-15,056$ & $-15,849$ & $-17,196$ & $-19,888$ \\
\hline Other items net & $-17,350$ & $-18,252$ & $-17,780$ & $-18,185$ & $-18,392$ & $-20,724$ \\
\hline Broad money (M4) & 131,641 & 136,361 & 142,041 & 140,666 & 152,794 & 172,514 \\
\hline
\end{tabular}

(12-month rate of growth, unless otherwise specified)

\begin{tabular}{|c|c|c|c|c|c|c|}
\hline Currency issue & 20.4 & 19.6 & 16.9 & 16.0 & 15.1 & 15.0 \\
\hline Currency in circulation & 23.2 & 19.6 & 16.9 & 16.0 & 16.4 & 15.0 \\
\hline Broad Money & 16.1 & 15.6 & 15.6 & 15.9 & 16.1 & 12.9 \\
\hline Credit to the Private Sector & 32.1 & 27.5 & 25.0 & 19.4 & 18.2 & 13.2 \\
\hline Letras $\mathrm{BCH}$ Total (millions of lempiras) & 16,705 & 17,109 & 16,809 & 17,016 & 16,915 & 23,347 \\
\hline M1 & 17.9 & 21.3 & 23.7 & 14.7 & 14.5 & 13.7 \\
\hline
\end{tabular}

Sources: Central Bank of Honduras; and Fund staff estimates. 
Table 5. Honduras: Balance of Payments

(In millions of U.S. dollars; unless otherwise indicated)

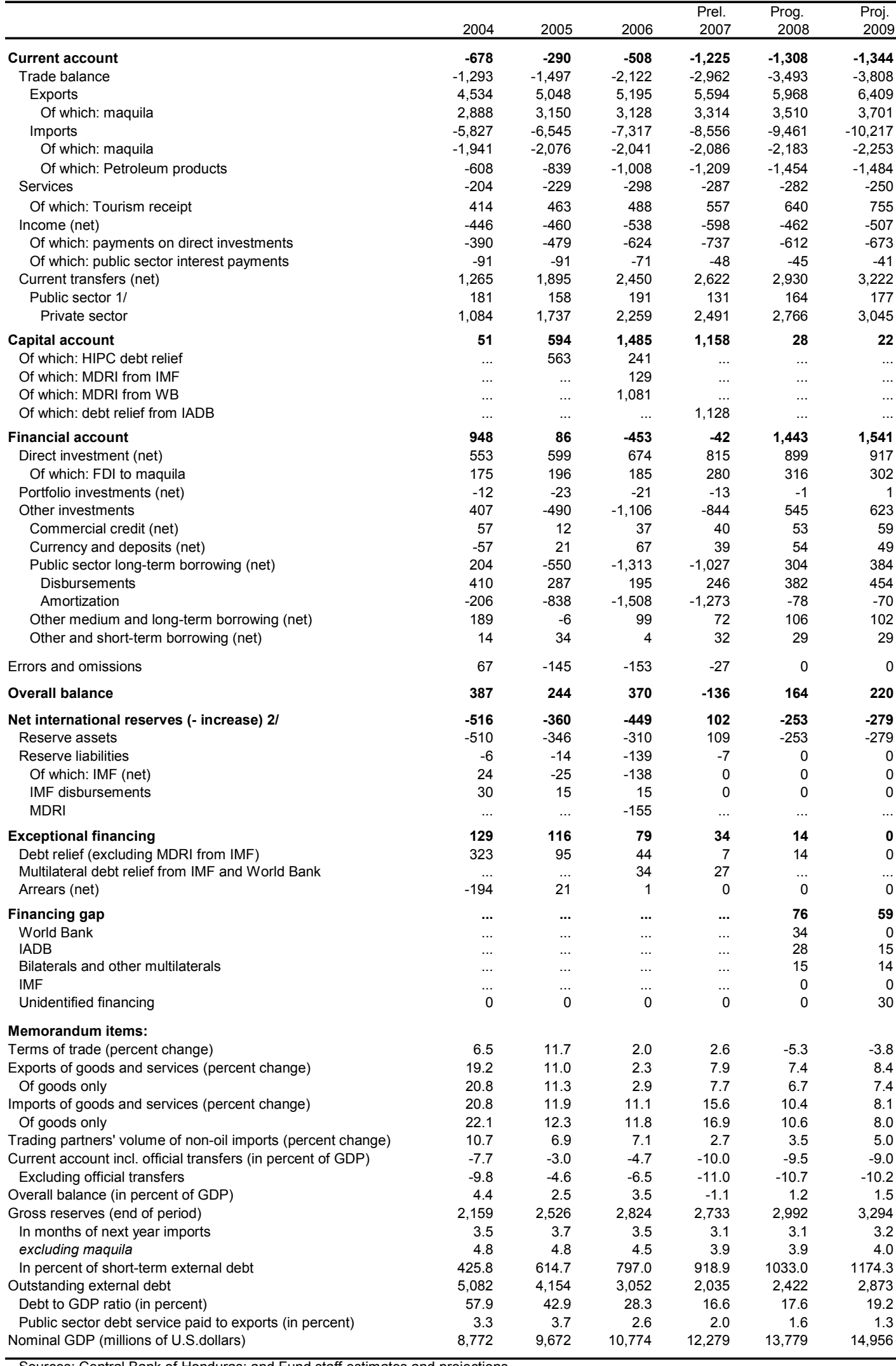

Sources: Central Bank of Honduras; and Fund staff estimates and projections.

1/ Includes HIPC grants from the FIDA, IDB, IMF (until 2005), and the World Bank (until June 2006).

$2 /$ Equals the sum of reserve assets, reserve liabilities, and IMF. 
Table 6. Honduras: Illustrative Medium-Term Scenario

\begin{tabular}{|c|c|c|c|c|c|c|c|c|c|}
\hline & 2005 & 2006 & 2007 & 2008 & 2009 & 2010 & 2011 & 2012 & 2013 \\
\hline & \multicolumn{9}{|c|}{ (annual percentage change) } \\
\hline \multicolumn{10}{|l|}{ Macroeconomic parameters } \\
\hline Real GDP & 6.1 & 6.3 & 6.3 & 4.8 & 4.6 & 4.5 & 4.4 & 4.2 & 4.2 \\
\hline Nominal GDP & 13.8 & 11.4 & 13.7 & 14.1 & 12.7 & 11.5 & 11.0 & 10.5 & 10.2 \\
\hline Implicit GDP deflator & 7.3 & 4.8 & 7.0 & 8.8 & 7.7 & 6.7 & 6.3 & 6.1 & 5.8 \\
\hline & \multicolumn{9}{|c|}{ (in percent of GDP, unless otherwise indicated) } \\
\hline \multicolumn{10}{|l|}{ Budget and public debt } \\
\hline Overall public sector balance & -1.4 & -1.7 & -2.3 & -1.5 & -1.5 & -1.5 & -1.6 & -1.8 & -1.8 \\
\hline Overall central government balance & -2.3 & -1.1 & -2.1 & -1.8 & -1.6 & -1.7 & -1.6 & -1.8 & -1.8 \\
\hline Public sector debt & 52.8 & 35.4 & 23.7 & 22.5 & 22.1 & 22.2 & 22.5 & 23.2 & 22.9 \\
\hline \multicolumn{10}{|l|}{ External sector } \\
\hline External current account balance & -3.0 & -4.7 & -10.0 & -9.5 & -9.0 & -7.8 & -6.7 & -6.1 & -6.0 \\
\hline Gross international reserves (US\$ millions) & 2,526 & 2,824 & 2,733 & 2,986 & 3,265 & 3,554 & 3,929 & 4,367 & 4,815 \\
\hline (in months of imports) $1 /$ & 4.8 & 4.5 & 3.9 & 3.9 & 3.9 & 4.0 & 4.1 & 4.2 & 4.3 \\
\hline Public sector external debt & 42.9 & 28.3 & 16.6 & 17.6 & 19.2 & 19.5 & 19.5 & 19.4 & 19.3 \\
\hline Gross domestic investment & 24.9 & 27.7 & 30.4 & 32.7 & 32.3 & 31.1 & 30.5 & 30.4 & 30.4 \\
\hline National savings & 21.9 & 23.0 & 20.4 & 23.2 & 23.3 & 23.3 & 23.8 & 24.4 & 24.4 \\
\hline
\end{tabular}

Sources: Central Bank of Honduras; Ministry of Finance; and Fund staff estimates.

$1 /$ Refers to the following year's imports of nonmaquila goods and nonfactor services.

Table 7. Honduras: Purchase Schedule and Terms under Proposed Stand-By Arrangement

\begin{tabular}{|c|c|c|c|c|c|}
\hline \multirow[b]{2}{*}{ Date } & \multirow[b]{2}{*}{ Conditions for purchase } & \multicolumn{4}{|c|}{ Purchase } \\
\hline & & SDR millions & US\$ millions & $\begin{array}{c}\text { Percent of } \\
\text { Quota }\end{array}$ & $\begin{array}{c}\text { Percent of } \\
\text { Total Access }\end{array}$ \\
\hline April 7, 2008 & Board approval of SBA & 32.375 & 52.61 & 25.00 & 83.33 \\
\hline August 15, 2008 & Based on end-June 2008 performance criteria (first review) & 2.175 & 3.53 & 1.68 & 5.60 \\
\hline November 15, 2008 & Based on end-September 2008 performance criteria (test date) & 2.150 & 3.49 & 1.66 & 5.53 \\
\hline February 15, 2009 & Based on end-December 2008 performance criteria (second review) & 2.150 & 3.49 & 1.66 & 5.53 \\
\hline Total access & & 38.850 & 63.13 & 30.00 & 100 \\
\hline
\end{tabular}


Table 8. Honduras: Indicators of Fund Credit

(In units indicated)

\begin{tabular}{|c|c|c|c|c|c|c|c|c|c|c|c|c|c|}
\hline & \multirow[b]{2}{*}{2001} & \multirow[b]{2}{*}{2002} & \multirow[b]{2}{*}{2003} & \multirow[b]{2}{*}{2004} & \multirow[b]{2}{*}{2005} & \multirow[b]{2}{*}{2006} & \multirow[b]{2}{*}{2007} & \multicolumn{6}{|c|}{ Projections } \\
\hline & & & & & & & & 2008 & 2009 & 2010 & 2011 & 2012 & 2013 \\
\hline \multicolumn{14}{|l|}{ Existing Fund credit } \\
\hline Stock, in millions of SDRs $1 /$ & 175.1 & 144.6 & 115.4 & 125.7 & 117.6 & 20.3 & 20.3 & 20.3 & 20.3 & 19.3 & 16.3 & 12.2 & 8.1 \\
\hline Obligations, in millions of SDRs & 10.3 & 32.7 & 30.7 & 11.0 & 19.2 & 0.5 & 0.9 & 0.7 & 0.7 & 1.7 & 3.7 & 4.7 & 4.7 \\
\hline \multicolumn{14}{|l|}{ Proposed SBA } \\
\hline Stock, in millions of SDRs $1 /$ & $\ldots$ & $\ldots$ & $\ldots$ & $\ldots$ & $\ldots$ & $\ldots$ & $\ldots$ & 36.7 & 38.9 & 30.5 & 11.3 & 0.3 & 0.0 \\
\hline Obligations, in millions of SDRs 2/ & $\ldots$ & $\ldots$ & $\ldots$ & $\ldots$ & $\ldots$ & $\ldots$ & $\ldots$ & 1.0 & 1.7 & 10.0 & 20.2 & 11.3 & 0.3 \\
\hline Principal & $\ldots$ & $\ldots$ & $\ldots$ & $\ldots$ & $\ldots$ & $\ldots$ & $\ldots$ & 0.0 & 0.0 & 8.4 & 19.2 & 11.1 & 0.3 \\
\hline Interest and charges & $\ldots$ & $\ldots$ & $\ldots$ & $\ldots$ & $\ldots$ & $\ldots$ & $\ldots$ & 1.0 & 1.7 & 1.6 & 1.0 & 0.2 & 0.0 \\
\hline \multicolumn{14}{|l|}{$\begin{array}{l}\text { Stock of existing } \\
\text { and prospective Fund credit } 1 /\end{array}$} \\
\hline In millions of SDRs & 175.1 & 144.6 & 115.4 & 125.7 & 117.6 & 20.3 & 20.3 & 57.0 & 59.2 & 49.8 & 27.6 & 12.5 & 8.1 \\
\hline In percent of quota & 135.2 & 111.7 & 89.1 & 97.1 & 90.8 & 15.7 & 15.7 & 44.0 & 45.7 & 38.2 & 21.0 & 9.4 & 6.1 \\
\hline In percent of exports of goods and services & 5.6 & 4.5 & 3.9 & 3.7 & 2.9 & 0.5 & 0.5 & 1.3 & 1.3 & 1.0 & 0.5 & 0.2 & 0.1 \\
\hline In percent of external debt & 4.9 & 4.2 & 3.5 & 3.8 & 4.1 & 1.0 & 1.6 & 3.7 & 3.3 & 2.6 & 1.4 & 0.6 & 0.4 \\
\hline In percent of gross reserves & 14.0 & 11.5 & 10.5 & 9.0 & 6.7 & 1.1 & 1.2 & 3.0 & 2.9 & 2.2 & 1.1 & 0.5 & 0.3 \\
\hline \multicolumn{14}{|l|}{$\begin{array}{l}\text { Obligations to the Fund from existing } \\
\text { and prospective Fund arrangements }\end{array}$} \\
\hline In millions of SDRs & 10.3 & 32.7 & 30.7 & 11.0 & 19.2 & 0.5 & 0.9 & 1.7 & 2.4 & 11.7 & 23.9 & 16.0 & 5.0 \\
\hline In percent of quota & 7.9 & 25.2 & 23.7 & 8.5 & 14.8 & 0.4 & 0.7 & 1.3 & 1.8 & 9.0 & 18.2 & 12.1 & 3.7 \\
\hline In percent of exports of goods and services & 0.3 & 1.0 & 1.0 & 0.3 & 0.5 & 0.0 & 0.0 & 0.0 & 0.1 & 0.2 & 0.4 & 0.3 & 0.1 \\
\hline In percent of external debt & 0.3 & 0.9 & 0.9 & 0.3 & 0.7 & 0.0 & 0.1 & 0.1 & 0.1 & 0.6 & 1.2 & 0.8 & 0.2 \\
\hline In percent of gross reserves & 0.8 & 2.6 & 2.8 & 0.8 & 1.1 & 0.0 & 0.1 & 0.1 & 0.1 & 0.5 & 1.0 & 0.6 & 0.2 \\
\hline
\end{tabular}

Sources: Central Bank of Honduras; and Fund staff estimates.

$1 /$ End of period.

2/Expected repayment schedule, assuming a constant 4.38 rate of charge. 
Table 9. Honduras: External Vulnerability Indicators

\begin{tabular}{|c|c|c|c|c|c|c|c|c|c|c|}
\hline & 2004 & 2005 & 2006 & 2007 & 2008 & 2009 & 2010 & 2011 & 2012 & 2013 \\
\hline & \multicolumn{10}{|c|}{ (percent change) } \\
\hline Exports of goods and services, U.S. dollars & 19.2 & 11.0 & 2.3 & 7.9 & 7.4 & 8.4 & 8.3 & 8.2 & 7.0 & 5.4 \\
\hline Imports of goods and services, U.S. dollars & 20.8 & 11.9 & 11.1 & 15.6 & 10.4 & 8.1 & 7.2 & 7.2 & 7.1 & 6.9 \\
\hline Terms of trade (deterioration -) & 6.5 & 11.7 & 2.0 & 2.6 & -5.3 & -3.8 & -6.4 & -3.3 & -3.1 & -3.6 \\
\hline \multirow[t]{2}{*}{ Real effective exchange rate, end-of-period } & -1.4 & 1.0 & 1.7 & 2.3 & $\cdots$ & $\ldots$ & $\ldots$ & $\cdots$ & $\cdots$ & $\ldots$ \\
\hline & \multicolumn{10}{|c|}{ (percent of GDP, unless otherwise indicated) } \\
\hline Current account balance & -7.7 & -3.0 & -4.7 & -10.0 & -9.5 & -9.0 & -7.8 & -6.7 & -6.1 & -6.0 \\
\hline Capital and financial account & 11.4 & 7.0 & 9.6 & 9.1 & 10.7 & 10.5 & 9.2 & 8.8 & 8.5 & 8.2 \\
\hline External public debt & 57.9 & 42.9 & 28.3 & 16.6 & 17.6 & 19.2 & 19.5 & 19.5 & 19.4 & 19.3 \\
\hline External public debt (in percent of exports of goods and services) & 98.1 & 72.3 & 51.9 & 32.1 & 35.5 & 38.9 & 39.0 & 38.0 & 37.2 & 36.8 \\
\hline Debt service on external public debt (in percent of exports of goods and services & 3.3 & 3.7 & 2.6 & 2.0 & 1.6 & 1.3 & 1.2 & 1.1 & 1.1 & 1.0 \\
\hline \multicolumn{11}{|l|}{ Gross official reserves } \\
\hline in millions of U.S. dollars & 2159 & 2526 & 2824 & 2733 & 2986 & 3265 & 3554 & 3929 & 4367 & 4815 \\
\hline in percent of short-term external debt & 425.8 & 614.7 & 797.0 & 918.8 & 1030.8 & 1163.9 & 1262.5 & 1376.9 & 1540.2 & 1645.4 \\
\hline in months of next year's imports of goods and nonfactor services & 3.5 & 3.7 & 3.5 & 3.1 & 3.1 & 3.2 & 3.2 & 3.3 & 3.5 & 3.6 \\
\hline excluding imports for maquila & 4.8 & 4.8 & 4.5 & 3.9 & 3.9 & 3.9 & 4.0 & 4.1 & 4.2 & 4.3 \\
\hline \multicolumn{11}{|l|}{ NIR } \\
\hline in millions of U.S. dollars & 1766 & 2126 & 2575 & 2473 & 2726 & 3005 & 3292 & 3668 & 4117 & 4560 \\
\hline in percent of short-term external debt & 348.4 & 517.4 & 726.7 & 831.5 & 941.1 & 1071.3 & 1169.5 & 1285.2 & 1452.2 & 1558.6 \\
\hline in months of next year's imports of goods and nonfactor services & 2.8 & 3.1 & 3.2 & 2.8 & 2.9 & 2.9 & 3.0 & 3.1 & 3.3 & 3.4 \\
\hline
\end{tabular}

Sources: Central Bank of Honduras; and Fund staff estimates. 
Table 10. Honduras: Structure and Performance of the Banking Sector (In percent, unless otherwise indicated)

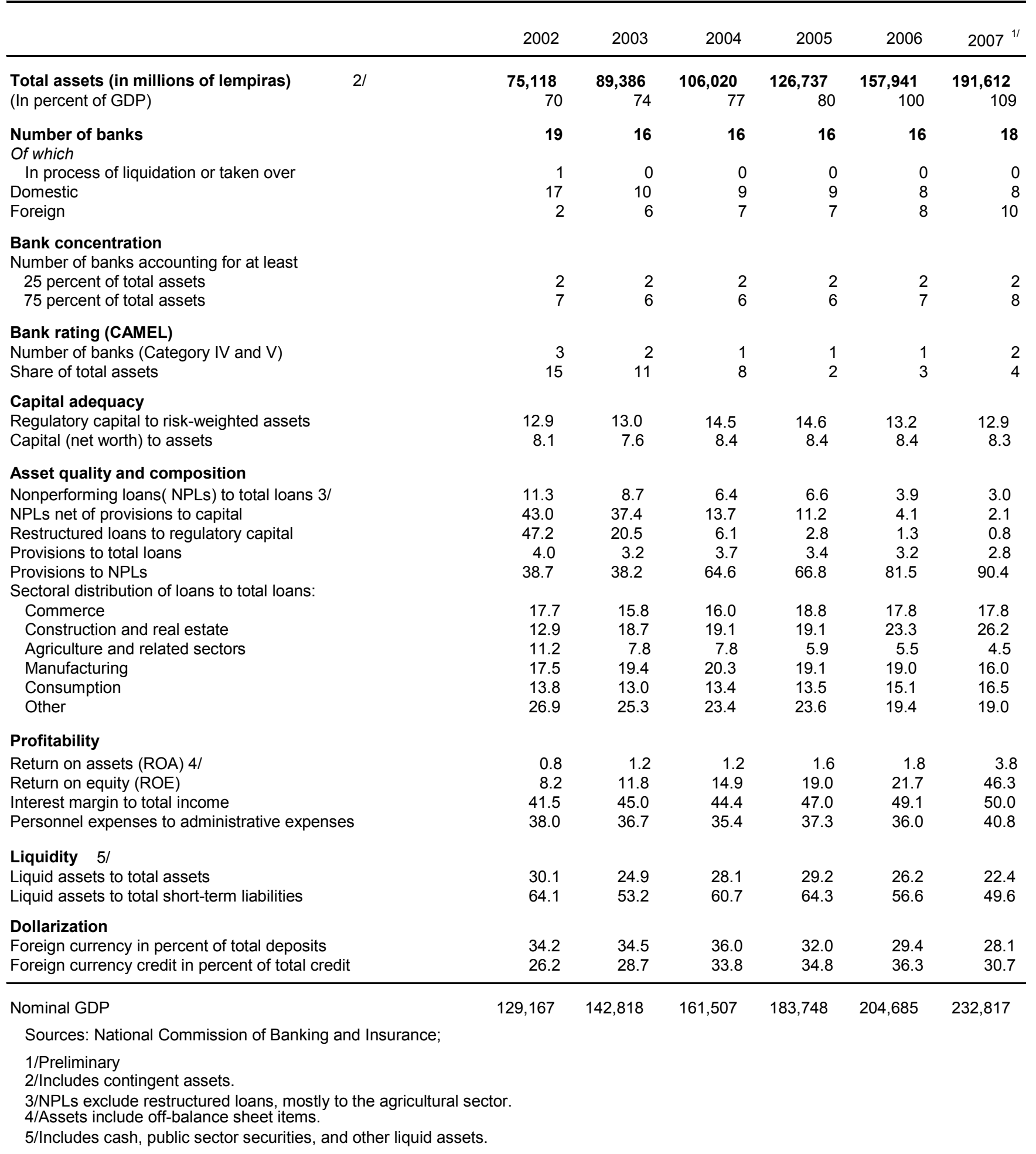




\section{Attachment I. The Authorities' Letter}

Tegucigalpa, March 24, 2008

Mr. Dominique Strauss-Kahn

Managing Director

International Monetary Fund

Washington DC, 20431

Dear Mr. Strauss-Kahn,

1. In recent years, the Honduran economy has enjoyed robust economic growth and declining poverty. To preserve these gains, within the context of a slowing global economy, the Government of Honduras intends to strengthen policies to address emerging economic imbalances. In support of its macroeconomic program for 2008, the Government is requesting a precautionary 12-month Stand-By Arrangement with the International Monetary Fund, in the amount of SDR 38.85 million, equivalent to 30 percent of Honduras' quota at the Fund.

2. In the enclosed Memorandum of Economic and Financial Policies (MEFP), we set out the goals and policies of the Government for 2008. These policies reflect the Government's commitment to high growth and macroeconomic stability, which are key conditions for further reducing poverty. The Government believes that the policies set forth in the attached MEFP are adequate to achieve the objectives of its program, but it will take any further measures that may become appropriate for the purpose. We will consult with the Fund on the adoption of these measures, and in advance of revisions to the policies contained in the MEFP, in accordance with the Fund's policies on such consultation. During the program, the Government will not introduce or intensify any exchange rate restrictions, multiple currency practice, and import restrictions for balance of payments purposes, nor conclude any bilateral payment agreements that are inconsistent with Article VIII of the Fund's Articles of Agreement.

3. Program implementation will be monitored through quarterly quantitative and structural performance criteria set forth in Tables 1 and 2 of the MEFP, and through quarterly reviews with the Fund, with the first review to be completed by August 2008. Consistent with the intention to keep the public informed, the Government will publish the MEFP and will report periodically on progress under the program.

Sincerely yours,

$\frac{/ \mathrm{s} /}{\text { Edwin Araque Bonilla }}$

President

Central Bank of Honduras
Rebeca Santos Rivera

Minister of Finance 


\section{Attachment II. Memorandum of Economic and Financial Policies of the Government of Honduras}

\section{Program ObJectives}

1. Over the last four years, economic performance in Honduras has been strong. Output has grown rapidly at over 6 percent per year, inflation remained in single digits, and poverty declined. Since 2007, however, world oil and agricultural prices have surged, and remittances decelerated, especially in 2006-07. Credit to the private sector expanded rapidly, boosting domestic demand (both private investment and consumption) and imports, and the budget helped smooth the oil shock and social demands. Thus, pressures emerged on inflation, public finances, the energy sector, and the balance of payments.

2. The Government of Honduras has developed a stabilization program to address these pressing challenges. The program aims to preserve the conditions for sustained growth and poverty reduction through the consolidation of macroeconomic stability. Within a context of a slowdown in the global economy, the program seeks to achieve real GDP growth of about 5 percent in 2008, maintain single-digit inflation, and strengthen the external position. The program also includes a comprehensive reform to put the energy sector on a sound footing.

3. To achieve these goals, the government is implementing a package of economic and financial policies. The 2008 budget will target a combined public sector deficit of $1 \frac{1}{2}$ percent of GDP, while increasing infrastructure and anti-poverty spending. The monetary program supports an expansion of bank credit in line with growth objectives and maintains international reserves at 4 months of nonmaquila imports. Exchange rate policy will be managed to help maintain external competitiveness. The package will support a decline in the external current account deficit to 6 percent of GDP over the medium term.

4. The government will continue to refine its medium-term policies for poverty alleviation and growth and, in coming months, plans to finalize a program that could be supported under the Poverty Reduction and Growth Facility. To this end, in consultation with the Honduran society, the government will develop an agenda to: strengthen the medium-term fiscal framework; implement a comprehensive wage policy consistent with a steady increase in key social and infrastructure spending; improve the energy sector; enhance the transparency of the budgetary process; improve public sector institutions and fight corruption; further modernize the financial system, and continue to enhance the investment climate and overall competitiveness. 


\section{Economic ANd Financial Policies}

\section{A. Fiscal Policy}

5. The 2008 budget (prior action) aims at containing the overall fiscal deficit at $1 \frac{1}{2}$ percent of GDP, down from $2 \frac{1 / 4}{4}$ percent of GDP in2007. This is consistent with a recovery in priority spending, with public investment rising 13aercent of GDP in 2008. Fiscal consolidation will continue in 2009 , with the overall deficit target contained at about $1 \frac{1}{2}$ percent of GDP, helping public debt (both external and domestic) to remain stable at $22 \frac{1}{2}$ percent of GDP and locking in the benefits ofsubstantial debt relief obtained in recent years. To attain these targets, the 2008 budget includes the following key actions:

- $\quad$ Stabilizing the wage bill. The central government wage bill will be held constant at 9.2 percent of GDP in 2008 and 9.1 percent of GDP in 2009 (indicative target). To this end, the Government will strictly adhere to the 2006 wage agreement with teachers; grant wage increases for other civil servants, in line with projected inflation; and offset increases in employment in 2008 in priority sectors of the central government with retirements and other steps consistent with the findings of ongoing censuses and audits to keep employment at the level of December 2007. Actions will be taken to tighten payroll control, through: (i) setting up a centralized unit for payroll monitoring at the Ministry of Finance by end-April 2008; (ii) fully integrating payroll management modules of the health ministry and the civil service with the integrated system of financial management, SIAFI by end-August 2008, with the design of the module for the education sector completed by January 2009; (iii) finalizing a census and auditing of teachers by end-August 2008 and start acting on any irregularities by endSeptember; and (iv) extending the census and audit to the rest of the central government, starting with the health sector, by end-September 2008 .

- $\quad$ Further strengthening tax policy and administration. The Government will make permanent an income tax surcharge (Aporte Solidario Temporal) of 5 percent in the 2008 budget and submit to congress a draft anti-tax evasion law in May to improve tax administration. It will also enforce strict compliance of regulations for the sales and income tax exemptions by June 2008. The annual yield from this strategy is estimated at 0.6 percent of GDP.

- $\quad$ Strengthening the operating balance of the main public enterprises. Key actions include: (i) implementing a tariff policy that covers operational costs over time and gradually modernizing ENEE (see below); (ii) introducing new temporary charges for international calls (US $\$ 0.03$ per minute), and the adoption, by the state company (HONDUTEL), of increased charges for fixed lines-increasing revenue by about 0.3 percent of GDP; and (iii) completing financial audits for the two largest public enterprises (ENEE and HONDUTEL) by June 2008 and designing modernization plans for 2009 by October 2008. 
- Increasing priority spending. Current primary spending of the central government will be contained at 15.8 percent of GDP (indicative ceiling), consistent with a redirection of spending to priority sectors. Anti-poverty spending will increase to 7.0 percent of GDP (indicative floor) and public sector investment will increase to 6.5 percent of GDP, with the investment plan placing priority on basic infrastructure such as roads, energy, and ports.

- $\quad$ Targeting subsidies to the poor. The direct electricity subsidy and the Bonochenta will be limited to users consuming less than $150 \mathrm{kwh}$ per month (from $300 \mathrm{kwh}$ ) in April. The direct fuel subsidy will be capped at L1000 million (0.4 percent of GDP) for 2008 and targeted to the poor. The Government will appoint a technical group to strengthen the targeting of the overall subsidy policy, and prepare by July 2008, a report with recommendations to improve delivery of subsidies and identify enhanced schemes to better target direct fuel subsidies.

- $\quad$ Adopting a policy of new lending consistent with loan recovery by the public pension funds. This policy is in line with the budget proposals of the public pension institutes and will result in fiscal savings of 0.8 percent of GDP in 2008. This measure will help contain the lending program of public pension institutes to their members, thus limiting the risk in their portfolios and protecting their financial integrity.

- $\quad$ Reliance on external financing. The Government intends to substantially reduce domestic financing, helping crowd in private investment. The policy of contracting external financing only on concessional terms will be maintained (performance criterion, ceiling). Concessional financing from Petrocaribe for US\$350 million in 2008-09 has been obtained; about US\$140 million of these resources have been earmarked in the 2008 budget for projects on transmission and distribution of energy during the period 2008-09, and the rest will be earmarked for energy projects on hydroelectric generation and other infrastructure projects in poor areas. To maintain transparency, the government has established a trust fund at the central bank to manage the resources from Petrocaribe; and the central bank will report periodically on the operations of the trust to a blue ribbon committee comprising civil society members. In addition, the Government intends to use one-time proceeds of 0.6 percent of GDP from the sale of a mobile phone band to finance already budgeted investments in productive infrastructure projects, mostly roads.

\section{B. Monetary, Exchange Rate, and Prudential Policies}

6. Monetary policy will contain inflation at 8-10 percent in 2008, consistent with the adjustment of energy prices, a sustainable expansion of bank credit to the private sector, and strengthened net international reserves (NIR). The central bank has raised its policy interest rate (by 25 bps to 73 percent in February) and is taking measures by an amount equivalent to 2 percentage points in reserve requirements (either by increasing obligatory investments with a monetary effect or through additional sales of central bank bills to nonbank local investors), to 
bring NIR at end-March to the level of end-2007 (prior action). The central bank began raising obligatory investments by 5 percentage points in March (starting with 2 percentage points and subsequent monthly increases until June), which can be met with government paper to facilitate the repayment of arrears to private generators. To protect growth in a context of deteriorating external conditions, the central bank is reducing reserve requirements (by 5 and 10 percentage points for local and U.S. dollar deposits, respectively, in monthly steps over the period March-November) to those banks directing credit to productive sectors. Starting endFebruary, the central bank intends to maintain the stock of open market bills at or above a monthly indicative target to meet the program targets. The effectiveness of the recent reforms on reserve requirements will be assessed during the first review of the program and amended, if needed.

7. The central bank will aim to preserve the stability of the current exchange rate system, which allows the value of the currency to be determined within a band $( \pm 7$ percent from a mid-point). Consistent with this framework, the central bank will use more actively its monetary and exchange rate policy instruments, in a manner consistent with safeguarding external competitiveness and helping protect the economy against external shocks and achieving the reserve target in the program. This policy will be underpinned by prudent monetary and wage policies and will be adjusted as necessary in the event of adverse external developments. The Fund will undertake a study by end-May to assess the exchange rate system and adequate responses to external shocks.

8. The central bank monetary program is consistent with a prudent expansion of bank credit to support the program objective for growth. To encourage banks to internalize risks from a rapid credit expansion and reorient credit toward productive enterprises, the Comisin Nacional de Banca y Seguros (CNBS) will issue stricter norms for loan classification and raise loan provisioning (mainly for consumption credit) in March 2008 that will be implemented during 2008. These measures are equivalent to about 0.2 percentage points of risk-weighted capital asset ratio. The CNBS will also issue a regulation on risk-based supervision to improve its supervisory capacity and facilitate observance of the new classification and provisioning norms (structural performance criterion, April 2008). Looking ahead, the $C N B S$ will develop a medium-term reform agenda, based on the findings and recommendations of the recent FSAP update.

\section{Energy Policy}

9. A center piece of the government program in 2008 is to implement a broad based strategy to strengthen the energy sector, expected to be supported by the World Bank and the IADB. This strategy is designed to: (i) put ENEE on a sustainable financial footing; (ii) improve the corporate governance of ENEE; (iii) reduce distribution losses and fraud, through congressional approval of anti-theft legislation in April 2008; and (iv) address a chronic under-investment in the sector. Of key importance from a macroeconomic perspective, is: 
- Implementing a tariff structure that covers operational costs. The Government will raise electricity tariffs by an average of 11 percent to cover ENEE's operational cost at current bunker prices (US\$72 per barrel), when a revised tariff structure, that better focuses subsidies on the poor, comes into effect in April (structural performance criterion). This revised tariff, set in accordance with the electricity law, will be adjusted periodically to fully pass-through any changes in international bunker prices. Government transfers will continue to cover ENEE's financial cost and investments in 2008, but will be phased out in the medium term as the company further improves its revenue stream.

- Resolving payment arrears. The 2008 budget authorizes the issuance of government bonds (L4 billion or 1 $1 \frac{2}{2}$ percent of GDP) to clear payment arrears of ENEE with private generators. Upon transfer of these funds from the central government to ENEE, all public sector arrears with ENNE ( $1 / 2$ percent of GDP) will be cleared. All arrears as of end-March 2008, of ENEE with private generators will be cleared by end-June 2008 (structural performance criterion). The new tariff policy will ensure that ENEE no longer falls into arrears with the private sector (quantitative performance criterion). The public sector will remain current on payments for electricity consumption.

\section{Institutional Strengthening}

10. The Government will implement a strategy to fight corruption and strengthen public institutions, which was presented to the international community in September 2007. Key actions include: providing legal protection to public employees involved in anti-corruption cases; reducing partisan influence in employment policy; disclosing financial statements of political parties and its financing, as well as on cabinet and high-level officials. With World Bank assistance, corporate governance and the AML/CFT framework will be strengthened.

\section{Program Monitoring}

11. The program will cover the economic program from January-December 2008 and will be monitored through quarterly reviews, with indicative targets for end-March and test dates for end-June, end-September, and end-December 2008 (Table 1). Prior actions and structural performance criteria are set out in Table 2. The definitions and reporting procedures are described in the attached Technical Memorandum of Understanding. 
Table 1. Honduras - Performance Criteria and Indicative Targets

(Cumulative flows from end-2007; millions of Lempiras, unless specified)

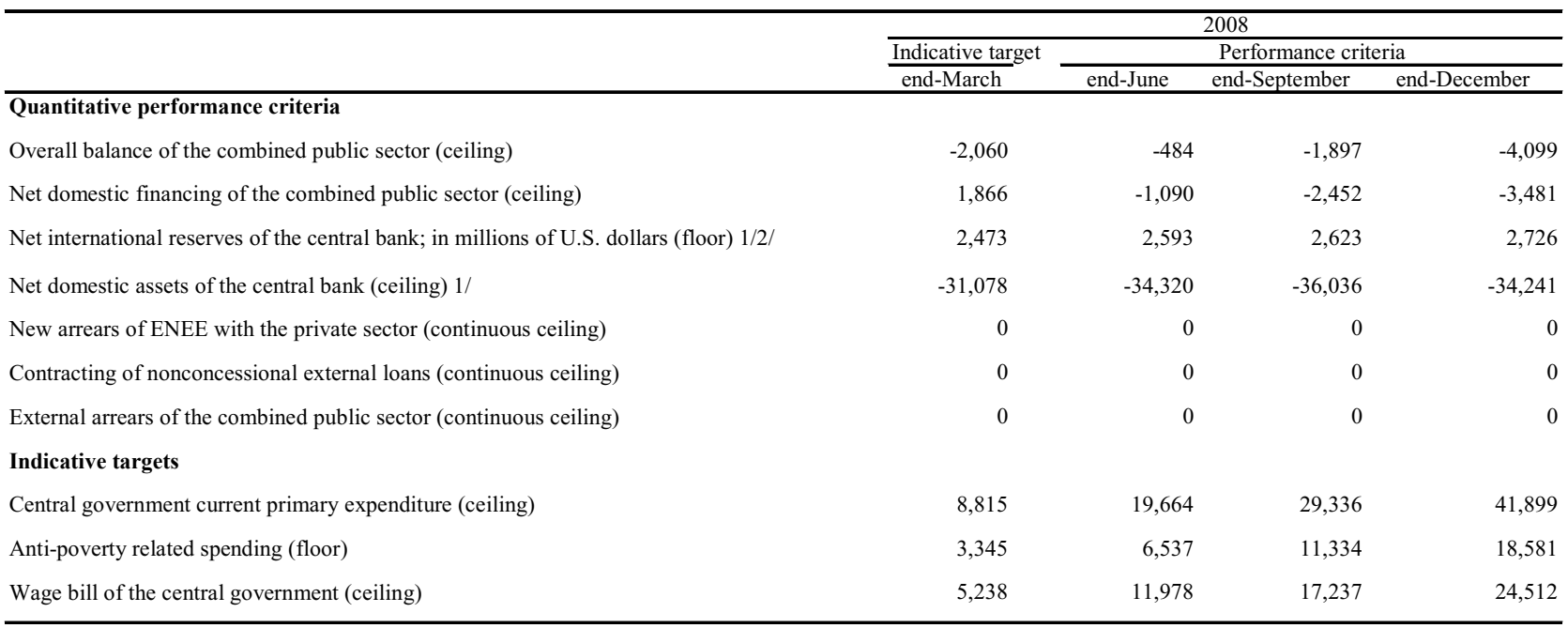

1/The end-June performance criterion for net international reserves will be adjusted downwards by up to US\$80 million if the foreign exchange proceeds from the sale of the mobile phone license are unrealized by that date. Conversely, the end-June performance criteria for net domestic assets of the central bank will be adjusted upwards by up to the same amount.

2/Prior action for end-March.

Table 2. Honduras - Prior Actions and Structural PCs

\begin{tabular}{l} 
Fiscal Policy \\
Congressional approval of the 2008 budget consistent with a combined public sector deficit of 1.5 percent \\
of GDP and the current expenditure indicative targets \\
Monetary Policy \\
Raise the policy interest rate by 25 bps and policy measures equivalent to 2 percentage points in reserve \\
requirements (either by increasing obligatory investments with a monetary effect or through additional sales \\
of central bank bills to non-bank local investors) \\
Bring NIR at end-March 2008 to the level of end-December 2007 \\
Energy Sector \\
Eliminate arrears of ENEE to generators (end-June, 2008) \\
Implementation of a tariff policy in the electricity sector to ensure operational cost recovery \\
(April, 2008, see details in MEFP, paragraph 9) \\
Financial Sector \\
Issue a regulation on risk-based supervision (see details in MEFP, paragraph 8, April 2008) \\
\hline
\end{tabular}

\section{CInternational Monetary Fund. Not for Redistribution}




\section{Attachment III. Technical Memorandum of Understanding}

1. This memorandum sets out technical understandings between the Honduran authorities and the Fund for monitoring the economic program during 2008 supported by a Stand-By Arrangement. It defines the concepts used to assess observance of quantitative performance criteria and benchmarks specified in Tables 1 and 2 of the Memorandum of Economic Policies (MEFP). It also specifies the frequency of the data to be provided to the Fund for monitoring the program.

\section{FisCAL TARgETS}

2. The deficit of the combined public sector (CPS) will be measured from the financing side, and corresponds to the net borrowing requirements of the CPS, from both external and domestic sources. The combined public sector comprises the nonfinancial public sector (NFPS) and the operating result (quasi-fiscal balance) of the central bank. The NFPS covers the central government (including its agencies), local governments and decentralized agencies, the social security institute (IHSS), the pension institutes for executive branch staff (INJUPEMP) and teachers (INPREMA), and the public enterprises.

3. The deficit of the central government will also be measured from the financing side. The central government includes the executive, judicial, and legislative branches of government. It consolidates the operations of trust funds created to support agricultural loans and so-called deconcentrated agencies.

4. The current primary expenditure of the central government is defined as total current expenditure less interest payments.

5. The central government wage bill is defined as all central government wages and salaries including severance payments, plus employer social security and pension contributions, and other remunerations (such as special bonuses and performance related remuneration to teachers under the $P A S C E$ ).

6. Anti-poverty spending comprises all spending on programs and projects of the Poverty Reduction Strategy (whether financed by domestic savings, HIPC debt relief, grants, and external loans), as defined in the relevant annex of the 2003 PRSP and the latest update to the PRS. Programs and projects in the PRSP will be labeled in the 2008 budget and tagged through the SIAFI. Anti-poverty spending will be presented by economic classification, type of program, and source of financing.

7. The operating surplus of the public enterprises is the difference between the operating revenue (excluding interest earnings and transfers) and the operating expenditure (excluding interest payments and transfers) of the enterprises. For the purposes of the program, the public enterprises comprise the State Electricity Company (ENEE), the State Telecommunications Company (HONDUTEL), the State Water and Sewerage Company (SANAA), and the State Ports Company (ENP). 
8. Net domestic financing of the CPS comprises the operating result of the central bank and the change relative to end-2007 in the stocks of: (1) outstanding indebtedness of the NFPS (direct bank credit plus bank holdings of public sector bonds less deposits) to the domestic financial system (central bank, commercial banks, and other financial institutions); (2) outstanding public sector bonds held outside the financial system; (3) outstanding deposits held abroad; (4) outstanding suppliers' credit and floating debt (uncashed and undelivered checks, and unpaid invoices and orders) of the central government, and unpaid orders of the rest of the NFPS (all domestic debt is in domestic currency); and (5) proceeds from the sale of the mobile phone license.

9. Discrepancies. The authorities will undertake periodic reconciliations to minimize discrepancies between above-the-line and financing data. If needed, these reconciliations should be carried out prior to completion of the first and second reviews under the program.

\section{MONETARY TARGETS}

10. Net International Reserves (NIR) of the central bank. For program purposes, NIR will be measured as gross international reserves that are readily available (including the balance of the Trust Fund instituted to manage financing from Petrocaribe) minus short-term reserve liabilities (including purchases and credits from the Fund), as described in the international reserves table prepared by the central bank according to the new monetary statistics presentation (MEMF). Readily available reserves also exclude those assets that are pledged or otherwise encumbered, including but not limited to reserve assets used as collateral or guarantee for a third-party external liability. NIR excludes (1) any conversion of short-term reserve liabilities; (2) foreign assets stemming from foreign currency deposits of financial institutions at the central bank; and (3) transfer to the central bank of foreign currency deposits of HONDUTEL, INJUPEMP, and IHSS held abroad, which amounted to US\$121 million at end-2007. NIR will be valued at current exchange rates.

11. Net domestic assets (NDA) of the central bank will be measured as the difference between currency issue and NIR, both measured on the basis of end-of-period data.

12. Prior action. Monetary measures equivalent to 2 percentage points in reserve requirements (MEFP $\$ 6$ ) will be defined over a base of end-December local currency deposits. The stock of central bank bills in the hands of nonbank local investors will be defined as the total stock of central bank bills less the stock in the hands of commercial banks (otras sociedades de deposito).

13. Adjustor: The end-June performance criterion for the floor on net international reserves of the central bank will be adjusted downwards by the amount of the proceeds from the sale of the mobile phone license that are unrealized by that date, or the amount of the proceeds that are realized in lempiras, by up to US\$80 million. Conversely, the end-June performance criterion for the ceiling on net domestic assets of the central bank will be adjusted upwards by up to the same amount. 


\section{EXTERNAL TARGETS}

14. External debt. As indicated in point No. 9 of the Guidelines on Performance Criteria with Respect to Foreign Debt adopted by the IMF Executive Board on August 24, 2000, debt will be defined as a current (not contingent) liability, created under a contractual arrangement through the provision of value in the form of assets (including currency) or services, and which requires the obligor to make one or more payments in the form of assets (including currency) or services, at some future point(s) in time; these payments will discharge the principal and/or interest liabilities incurred under the contract. Debts can take a number of forms: (i) loans, i.e., advances of money to obligor by the lender made on the basis of an undertaking that the obligor will repay the funds in the future (including deposits, bonds, debentures, commercial loans, and buyers' credits) and temporary exchanges of assets that are equivalent to fully collateralized loans under which the obligor is required to repay the funds, and usually pay interest, by repurchasing the collateral from the buyer in the future (such as repurchase agreements and official swap arrangements); (ii) suppliers' credits, i.e., contracts where the supplier permits the obligor to defer payments until some time after the date on which the goods are delivered or services are provided; and (iii) leases, i.e., arrangements under which property is provided which the lessee has the right to use for one or more specified period(s) of time that are usually shorter than the total expected service life of the property, while the lessor retains the title to the property. For the purpose of the guideline, the debt is the present value (at the inception of the lease) of all lease payments expected to be made during the period of the agreement excluding those payments that cover the operation, repair, or maintenance of the property. (b) Under the definition of debt set out above, arrears, penalties, and judicially awarded damages arising from the failure to make payment under a contractual obligation that constitutes debt are debt. Failure to make payment on an obligation that is not considered debt under this definition (e.g., payment on delivery) will not give rise to debt."

15. Stock of external debt arrears. For the purpose of the program ceiling, external debtservice arrears are defined as overdue debt service arising in respect of obligations incurred directly or guaranteed by the public sector, except on debt subject to rescheduling or restructuring, as indicated by the respective creditors.

16. Borrowing on nonconcessional terms. For the purposes of the program, this ceiling applies to the contracting or guaranteeing of nonconcessional external debt by the CPS or any other agencies on their behalf. The ceiling applies not only to debt as defined above, but also to commitments contracted or guaranteed for which value has not been received.

17. Concessionality will be based on a currency-specific discount rate based on the 10 year (6-month) average of the OECD's commercial interest reference rates (CIRR) for loans or leases with maturities greater (less) than 15 years, and following the methodology set out in Fund documents of April 8, 1996 and June 30, 2000. Maturity will be determined on the basis of the original loan contract. Under this definition of concessionality, only debt with a grant element equivalent to at least 35 percent (referring to the difference between the nominal 
value and the net present value of debt) will be excluded from the debt ceiling. In determining whether multiple financing instruments would be considered as an integrated incurrence of debt for the purposes of assessing the concessionality of that debt, the elements that Fund staff would take into account include: (i) identical intended use or purposes for the financing; (ii) inter-related schedules for disbursement; (iii) cross-conditions for entry into legal effect, availability of funds and default; and (iv) identical parties to the financing.

18. Excluded from the external debt ceiling are: (1) the use of Fund resources; (2) debts classified as international reserve liabilities of the central bank; (3) short-term import financing (with a maturity of less than one year); (4) debts to restructure, refinance, or prepay existing debts; and (5) central bank instruments placed in the domestic market held by nonresidents.

\section{STRUCTURAL REFORMS}

\section{E. Energy Policy}

19. Arrears of ENEE are defined as overdue payments (principal and interest) as stipulated in the corresponding contracts. With proceeds from the issue of government bonds authorized in the 2008 budget, ENEE will clear all arrears to generators by end-June 2008. No new arrears to the private sector shall accumulate during 2008.

\section{F. Monitoring and Reporting Requirements}

\section{The information required to monitor the compliance with quantitative and} structural performance criteria and benchmarks specified in the MEFP will be supplied to the Fund at least monthly (electronically, to the extent possible) within 45 days of the end of the previous month (unless otherwise noted) according to the following sources:

21. The ceilings on the deficit of the central government and of the CPS will be monitored below-the-line on the basis of the monthly reports Financiamiento de la Administraciú Central and Financiamiento del Sector Público Combinado, respectively, prepared by the central bank, which contain:

- $\quad$ Net external financing of the central government and the NFPS, respectively, with detailed information on disbursements, amortizations, exceptional financing, zerocoupon bond, and accumulation of arrears. This information is prepared by the central bank and reconciled with the Ministry of Finance.

- Net domestic financing of the central government and the NFPS, respectively, with detailed information on: (1) net domestic financing from the central bank and the rest of the financial system to the central government and the NFPS, as contained in the Panorama Financiero monthly report; (2) net placement of bonds (including stabilization bonds) by the central government and the NFPS outside the financial system, as reported by the central bank with data from the Public Credit Directorate of the Ministry of Finance; (3) change in foreign currency deposits held abroad by the 
central government and the NFPS; and (4) change in the outstanding stock of suppliers' credit and floating debt of the central government, as reported by the Treasury, and the rest of the NFPS as reported by the central bank. To monitor the net domestic financing to the CPS, the central bank will provide the Fund with detailed data on a cash basis on the operating revenue and expenditure of the central bank.

22. The ceilings on the wage bill of the central government will be monitored monthly on the basis of the ministry of finance report: Informaciń institucional por objeto de gasto servicios personales y aportes patronales.

23. To complement the monitoring of fiscal performance, a breakdown of tax revenue by type of tax will also be provided monthly to the Fund.

24. Anti-poverty spending will be monitored quarterly on the basis of the information provided by the ministry of finance. Anti-poverty spending will be obtained from the detailed central government report: Cuenta Financiera. The Ministry of Finance will also provide the breakdown between anti-poverty and other spending by expenditure category (i.e., wages and salaries, goods and services, current transfers, fixed capital formation, and capital transfers).

25. The floor on NIR and the ceiling on NDA of the central bank will be monitored on the basis of information produced by the central bank, in accordance with the new presentation of the monetary statistics (MEMF). This information will be provided within two weeks of the end of the previous month.

\section{The ceilings on the contracting of nonconcessional external debt and on the} nonaccumulation of external payments arrears will be monitored with information provided by the Ministry of Finance. The accounting of nonreschedulable external debt-service arrears by creditor (if any), with detailed explanations, will be transmitted by the Ministry of Finance on a monthly basis within four weeks of the end of each month. Moreover, a loan-byloan accounting of all new loans contracted or guaranteed by the public sector, including detailed information on the amounts, currencies, and terms and conditions, as well as relevant supporting materials, will be transmitted by the central bank on a quarterly basis within four weeks of the end of each quarter. 


\title{
Appendix II. Assessing External and Public Sector Debt Sustainability ${ }^{1}$
}

\begin{abstract}
Honduras' debt ratios will remain below their indicative thresholds and resilient to shocks over the medium and long term. This reflects low initial debt ratios and the projected consolidation of macro stability. After receiving debt relief under the HIPC Initiative and MDRI, the NPV of Honduras external debt declined to 12 percent of GDP at end-2007. Honduras reached the Completion Point under the HIPC initiative in April 2005 and received over US $\$ 800$ million in stock of debt reduction. The debt was reduced further by US\$2.3 billion when additional stock of debt relief was provided by the IMF and the World Bank in 2006 under MDRI and by the IDB in 2007. As a result, the external debt-to-GDP ratio declined from 60 percent of GDP at end-2003 to 16 percent at end-2007. Debt to multilateral institutions represented about 77 percent of the total stock of debt at end-2007.
\end{abstract}

\section{The baseline scenario assumes low fiscal and current account deficits, low inflation, and} sustained growth over the medium and long run. In the short run, a stabilization program will contain demand pressures, initiate a sustainable energy policy, increase public investment, and make permanent recent revenue gains. In the medium term, structural reforms will sustain growth in traditional sectors, and a better investment climate will spur growth in maquila, tourism, construction, and the financial sector, contributing to the consolidation of macroeconomic stability. Uncertainties in the external environment (in the medium term) and stabilization of migratory flows (in the long run) will contribute to a slow-down in the growth of remittances. Sound fiscal policy will keep the overall fiscal balance below 2 percent of GDP, and investments in the energy sector will help reduce dependency on imported fuel. As a result, long-run growth will stabilize at 4.2 percent, and export and import growth will stabilize at about 8 and 7 percent, respectively, allowing the current account deficit to remain below 6 percent of GDP (on average). Financing will remain mostly external and concessional for the medium term, although at a declining rate of concessionality. ${ }^{2}$ In the long-run, after Honduras' likely graduation from concessional multilateral donor financing, the grant element of new debt will decline below 35 percent.

Honduras' external debt ratios will remain stable under the baseline scenario, with the debt outlook remaining robust under alternative scenarios. The NPV of debt-to-GDP will remain below 14 percent over the horizon of the analysis; only under extreme negative shocks does this ratio peak at 32 percent in 2013. Similarly, all relevant debt ratios remain stable under the

\footnotetext{
${ }^{1}$ This is a Fund staff update of the joint World Bank/IMF DSA conducted in Country Report 06/442. The annual joint World Bank/IMF DSA will be prepared at the occasion of the next Article IV Consultation.

${ }^{2}$ According to Honduras' public sector credit norms, it can borrow externally only on concessional terms.
} 
baseline scenario and substantially below the indicative debt burden thresholds under the extreme stress test. ${ }^{3}$

Honduras' public debt will continue on a sustainable path. The NPV of public debt-to-GDP will remain below 20 percent under the baseline scenario, and below 40 percent under the most extreme stress test (a permanent decline in GDP). Consolidation of improvements in revenue administration will be key to keep the debt service ratio at current levels.

\footnotetext{
${ }^{3}$ The thresholds are determined by the World Bank's Country Policy and Institutional Assessment (CPIA) rating. In 2005, Honduras was upgraded from a medium to a strong performer, and Honduras remained a strong performer since then, with a CPIA rating of 3.9 on a scale of 1 to 6 .
} 
Table 1. Honduras: External Debt Sustainability Framework, Baseline Scenario, 2005-2028 1/ (In percent of GDP, unless otherwise indicated)

\begin{tabular}{|c|c|c|c|c|c|c|c|c|c|c|c|c|c|c|c|}
\hline & \multicolumn{3}{|c|}{ Actual } & \multirow{2}{*}{$\begin{array}{c}\text { Historical } \\
\text { Average 6/ }\end{array}$} & \multirow{2}{*}{$\begin{array}{c}\text { Standard } \\
\text { Deviation 6/ }\end{array}$} & \multicolumn{10}{|c|}{ Projections } \\
\hline & 2005 & 2006 & 2007 & & & 2008 & 2009 & 2010 & 2011 & 2012 & 2013 & $\begin{array}{l}2007-12 \\
\text { Average }\end{array}$ & 2018 & 2028 & $\begin{array}{l}2013-27 \\
\text { Average }\end{array}$ \\
\hline External debt (nominal) $1 /$ & 45.3 & 30.3 & 18.4 & & & 19.2 & 20.7 & 20.9 & 20.7 & 20.6 & 20.5 & & 18.4 & 12.7 & \\
\hline o/w public and publicly guaranteed (PPG) & 42.9 & 28.3 & 16.6 & & & 17.6 & 19.2 & 19.5 & 19.5 & 19.4 & 19.3 & & 17.5 & 12.4 & \\
\hline Change in external debt & -15.3 & -15.0 & -12.0 & & & 0.8 & 1.5 & 0.2 & -0.2 & -0.1 & -0.1 & & -0.6 & -0.4 & \\
\hline Identified net debt-creating flows & -8.8 & -6.2 & -0.4 & & & 2.2 & 2.0 & 0.7 & -0.2 & -0.5 & -0.4 & & 0.1 & -1.2 & \\
\hline Noninterest current account deficit & 2.1 & 4.1 & 9.6 & 5.0 & 2.4 & 8.9 & 8.4 & 7.3 & 6.2 & 5.7 & 5.6 & & 6.1 & 4.6 & 5.6 \\
\hline Deficit in balance of goods and services & 17.8 & 22.5 & 26.5 & & & 27.4 & 27.1 & 26.8 & 26.7 & 27.2 & 28.4 & & 27.0 & 15.8 & \\
\hline Exports & 59.4 & 54.6 & 51.7 & & & 49.5 & 49.4 & 50.2 & 51.4 & 52.2 & 52.4 & & 53.2 & 45.9 & \\
\hline Imports & 77.3 & 77.0 & 78.1 & & & 76.8 & 76.5 & 76.9 & 78.0 & 79.4 & 80.8 & & 80.2 & 61.7 & \\
\hline Net current transfers (negative $=$ inflow) & -19.6 & -22.7 & -21.4 & -14.8 & 5.8 & -21.3 & -21.5 & -22.2 & -23.1 & -24.1 & -25.5 & & -24.3 & -14.4 & -20.9 \\
\hline o/w official & -1.6 & -1.8 & -1.1 & & & -1.2 & -1.2 & -1.2 & -1.2 & -1.2 & -1.1 & & -1.0 & -1.0 & \\
\hline Other current account flows (negative = net inflow) & 3.8 & 4.3 & 4.5 & & & 2.7 & 2.9 & 2.7 & 2.6 & 2.5 & 2.7 & & 3.4 & 3.2 & \\
\hline Net FDI (negative $=$ inflow) & -6.2 & -6.3 & -6.6 & -5.4 & 1.2 & -6.5 & -6.1 & -6.2 & -6.0 & -5.8 & -5.6 & & -5.6 & -5.6 & -5.6 \\
\hline Endogenous debt dynamics $2 /$ & -4.7 & -4.0 & -3.3 & & & -0.2 & -0.3 & -0.3 & -0.4 & -0.4 & -0.4 & & -0.3 & -0.2 & \\
\hline Contribution from nominal interest rate & 0.9 & 0.7 & 0.4 & & & 0.6 & 0.5 & 0.5 & 0.5 & 0.5 & 0.4 & & 0.4 & 0.3 & \\
\hline Contribution from real GDP growth & -3.3 & -2.6 & -1.7 & & & -0.8 & -0.8 & -0.9 & -0.9 & -0.8 & -0.8 & & -0.7 & -0.5 & \\
\hline Contribution from price and exchange rate changes & -2.3 & -2.0 & -2.0 & & & $\ldots$ & $\ldots$ & $\ldots$ & $\ldots$ & $\ldots$ & $\ldots$ & & $\ldots$ & $\ldots$ & \\
\hline Residual (3-4) 3/ & -6.5 & -8.8 & -11.6 & & & -1.3 & -0.5 & -0.6 & 0.0 & 0.4 & 0.3 & & -0.7 & 0.8 & \\
\hline o/w exceptional financing & -1.2 & -0.7 & -0.3 & & & -0.1 & -0.1 & 0.0 & 0.0 & 0.0 & 0.0 & & 0.0 & 0.0 & \\
\hline NPV of external debt 4 / & $\ldots$ & $\ldots$ & 12.1 & & & 12.4 & 13.3 & 13.4 & 13.4 & 13.5 & 13.6 & & 13.1 & 9.3 & \\
\hline In percent of exports & $\ldots$ & $\ldots$ & 23.4 & & & 25.1 & 26.9 & 26.8 & 26.1 & 25.9 & 26.0 & & 24.7 & 20.3 & \\
\hline NPV of PPG external debt & $\ldots$ & $\ldots$ & 10.3 & & & 10.8 & 11.8 & 12.1 & 12.1 & 12.3 & 12.5 & & 12.3 & 9.0 & \\
\hline In percent of exports & $\ldots$ & $\ldots$ & 19.9 & & & 21.9 & 24.0 & 24.0 & 23.6 & 23.5 & 23.8 & & 23.1 & 19.6 & \\
\hline In percent of government revenues & $\ldots$ & $\ldots$ & 59.1 & & & 58.7 & 51.3 & 52.3 & 52.2 & 52.6 & 53.0 & & 53.4 & 39.1 & \\
\hline Debt service-to-exports ratio (in percent) & 15.7 & 26.2 & 20.7 & & & 5.1 & 4.5 & 4.3 & 3.9 & 3.6 & 3.4 & & 3.1 & 2.6 & \\
\hline PPG debt service-to-exports ratio (in percent) & 11.3 & 22.2 & 17.1 & & & 1.7 & 1.5 & 1.4 & 1.3 & 1.2 & 1.1 & & 1.4 & 1.7 & \\
\hline PPG debt service-to-revenue ratio (in percent) & 41.1 & 72.6 & 50.8 & & & 4.7 & 3.2 & 3.1 & 2.9 & 2.6 & 2.5 & & 3.1 & 3.3 & \\
\hline Total gross financing need (billions of U.S. dollars) & 0.5 & 1.3 & 1.7 & & & 0.7 & 0.7 & 0.5 & 0.4 & 0.3 & 0.4 & & 0.6 & 0.2 & \\
\hline Noninterest current account deficit that stabilizes debt ratio & 17.3 & 19.0 & 21.6 & & & 8.0 & 6.9 & 7.1 & 6.4 & 5.7 & 5.7 & & 6.6 & 5.0 & \\
\hline \multicolumn{16}{|l|}{ Key macroeconomic assumptions } \\
\hline Real GDP growth (in percent) & 6.1 & 6.3 & 6.3 & 5.1 & 1.5 & 4.8 & 4.6 & 4.5 & 4.4 & 4.2 & 4.2 & 4.5 & 4.2 & 4.2 & 4.2 \\
\hline GDP deflator in U.S. dollar terms (change in percent) & 4.0 & 4.6 & 7.2 & 2.9 & 2.8 & 7.0 & 3.8 & 2.0 & 1.2 & 1.0 & 0.7 & 2.6 & 3.4 & 5.5 & 4.3 \\
\hline Effective interest rate (percent) $5 /$ & 1.7 & 1.6 & 1.5 & 2.0 & 0.4 & 3.8 & 3.0 & 2.7 & 2.3 & 2.3 & 2.3 & 2.7 & 2.3 & 2.6 & 2.4 \\
\hline Growth of exports of G\&S (U.S. dollar terms, in percent) & 11.0 & 2.3 & 7.9 & 7.5 & 6.4 & 7.4 & 8.4 & 8.3 & 8.2 & 7.0 & 5.4 & 7.5 & 8.0 & 8.0 & 7.7 \\
\hline Growth of imports of G\&S (U.S. dollar terms, in percent) & 11.9 & 11.1 & 15.6 & 10.9 & 5.9 & 10.4 & 8.1 & 7.2 & 7.2 & 7.1 & 6.9 & 7.8 & 6.8 & 6.8 & 6.7 \\
\hline Grant element of new public sector borrowing (in percent) & $\ldots$ & $\ldots$ & $\ldots$ & $\ldots$ & $\ldots$ & 38.8 & 39.3 & 39.7 & 38.9 & 36.0 & 35.7 & 38.1 & 31.9 & 30.9 & 31.6 \\
\hline Aid flows (in billions of US dollars) $7 /$ & 1.1 & 1.9 & 1.5 & & & 0.6 & 0.7 & 0.5 & 0.4 & 0.4 & 0.4 & & 0.6 & 1.5 & \\
\hline o/w Grants & 0.2 & 0.2 & 0.1 & & & 0.2 & 0.2 & 0.2 & 0.2 & 0.2 & 0.2 & & 0.3 & 0.6 & \\
\hline o/w Concessional loans & 0.3 & 0.2 & 0.2 & & & 0.5 & 0.5 & 0.3 & 0.2 & 0.2 & 0.2 & & 0.3 & 0.9 & \\
\hline Grant-equivalent financing (in percent of GDP) $8 /$ & $\ldots$ & $\ldots$ & $\ldots$ & & & 2.5 & 2.5 & 1.9 & 1.7 & 1.6 & 1.5 & & 1.4 & 1.4 & 1.5 \\
\hline Grant-equivalent financing (in percent of external financing) 8/ & $\ldots$ & $\ldots$ & $\ldots$ & & & 54.9 & 54.9 & 63.1 & 67.7 & 66.7 & 66.7 & & 61.7 & 59.9 & 61.2 \\
\hline \multicolumn{16}{|l|}{ Memorandum items: } \\
\hline Nominal GDP (billions of U.S. dollars) & 9.7 & 10.8 & 12.3 & & & 13.8 & 15.0 & 15.9 & 16.9 & 17.7 & 18.6 & & 25.7 & 64.5 & \\
\hline (NPVt-NPVt-1)/GDPt-1 (in percent) & & & & & & 1.9 & 2.0 & 1.0 & 0.7 & 0.8 & 0.8 & 1.2 & 0.8 & 0.7 & 0.7 \\
\hline
\end{tabular}

\footnotetext{
Source: Fund staff simulations.
}

$1 /$ Includes both public and private sector external debt.

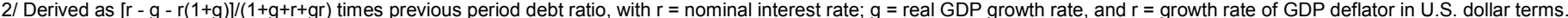

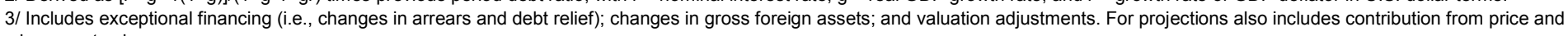
exchange rate changes.

4/ Assumes that NPV of private sector debt is equivalent to its face value.

5/ Current-year interest payments divided by previous period debt stock.

6/ Historical averages and standard deviations are generally derived over the past 10 years, subject to data availability.

7/ Defined as grants, concessional loans, and debt relief.

8/ Grant-equivalent financing includes grants provided directly to the government and through new borrowing (difference between the face value and the NPV of new debt). 
Table 2a. Honduras: Sensitivity Analyses for Key Indicators of Public and Publicly Guaranteed External Debt, 2008-28 (In percent)

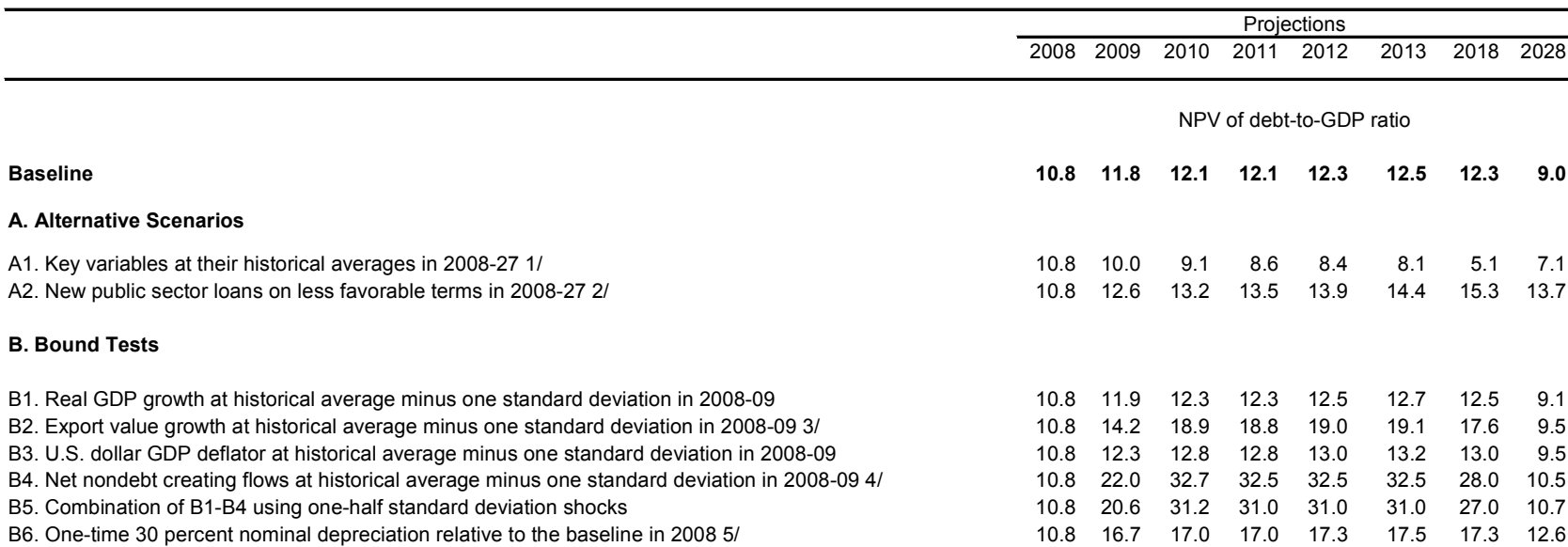

\section{Baseline}

NPV of debt-to-exports ratio

\section{A. Alternative Scenarios}

A1. Key variables at their historical averages in 2007-26 1/

A2. New public sector loans on less favorable terms in 2007-26 2/

$\begin{array}{rrrrrrrr}21.9 & 20.2 & 18.1 & 16.7 & 16.0 & 15.4 & 9.6 & 15.6 \\ 21.9 & 25.4 & 26.3 & 26.3 & 26.7 & 27.4 & 28.7 & 29.9\end{array}$

\section{B. Bound Tests}

B1. Real GDP growth at historical average minus one standard deviation in 2008-09

B2. Export value growth at historical average minus one standard deviation in 2008-09 3/

B3. U.S. dollar GDP deflator at historical average minus one standard deviation in 2008-09

B4. Net non-debt creating flows at historical average minus one standard deviation in 2008-09 4/

B5. Combination of B1-B4 using one-half standard deviation shocks

B6. One-time 30 percent nominal depreciation relative to the baseline in 2008 5/

$\begin{array}{llllllll}21.9 & 24.0 & 24.0 & 23.6 & 23.5 & 23.8 & 23.1 & 19.6 \\ 21.9 & 30.7 & 43.2 & 42.1 & 41.7 & 41.8 & 37.8 & 23.8 \\ 21.9 & 24.0 & 24.0 & 23.6 & 23.5 & 23.8 & 23.1 & 19.6 \\ 21.9 & 44.6 & 65.3 & 63.3 & 62.2 & 62.0 & 52.6 & 22.9 \\ 21.9 & 42.4 & 65.0 & 63.1 & 62.0 & 61.9 & 53.0 & 24.4 \\ 21.9 & 24.0 & 24.0 & 23.6 & 23.5 & 23.8 & 23.1 & 19.6\end{array}$

NPV of debt-to-evenue ratio

Baseline

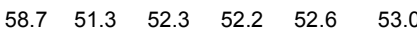

\section{A. Alternative Scenarios}

A1. Key variables at their historical averages in 2007-26 1/

A2. New public sector loans on less favorable terms in 2007-26 2 /

$\begin{array}{llllllll}58.7 & 43.3 & 39.4 & 36.9 & 35.8 & 34.3 & 22.1 & 31.0\end{array}$

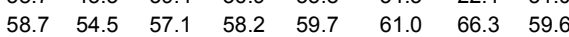

\section{B. Bound Tests}

B1. Real GDP growth at historical average minus one standard deviation in 2008-09

B2. Export value growth at historical average minus one standard deviation in 2008-09 $3 /$

B3. U.S. dollar GDP deflator at historical average minus one standard deviation in 2008-09

B4. Net nondebt creating flows at historical average minus one standard deviation in 2008-09 4/

B5. Combination of B1-B4 using one-half standard deviation shocks

B6. One-time 30 percent nominal depreciation relative to the baseline in 20085 /

$\begin{array}{rrrrrrrr}58.7 & 51.8 & 53.2 & 53.1 & 53.5 & 53.9 & 54.3 & 39.7 \\ 58.7 & 61.4 & 81.8 & 81.2 & 81.2 & 81.1 & 76.3 & 41.4 \\ 58.7 & 53.2 & 55.3 & 55.2 & 55.7 & 56.0 & 56.5 & 41.3 \\ 58.7 & 95.5 & 141.8 & 140.0 & 139.1 & 138.2 & 121.7 & 45.7 \\ 58.7 & 89.4 & 135.1 & 133.5 & 132.7 & 131.9 & 117.2 & 46.4 \\ 58.7 & 72.2 & 73.5 & 73.4 & 74.0 & 74.5 & 75.1 & 55.0\end{array}$

\section{CInternational Monetary Fund. Not for Redistribution}


Table 2b. Honduras: Sensitivity Analyses for Key Indicators of Public and Publicly Guaranteed External Debt, 2008-28 (In percent)

Debt service-to-exports ratio

\section{Baseline}

\section{A. Alternative Scenarios}

A1. Key variables at their historical averages in 2008-27 1/

A2. New public sector loans on less favorable terms in 2008-27 $2 /$

\section{B. Bound Tests}

B1. Real GDP growth at historical average minus one standard deviation in 2008-09

B2. Export value growth at historical average minus one standard deviation in 2008-09 3/

B3. U.S. dollar GDP deflator at historical average minus one standard deviation in 2008-09

B4. Net nondebt creating flows at historical average minus one standard deviation in 2008-09 4/

B5. Combination of B1-B4 using one-half standard deviation shocks

B6. One-time 30 percent nominal depreciation relative to the baseline in 2008 5/

Debt service-to-revenue ratio

\section{Baseline}

\section{A. Alternative Scenarios}

A1. Key variables at their historical averages in 2008-27 1/

A2. New public sector loans on less favorable terms in 2008-27 2/

\section{B. Bound Tests}

B1. Real GDP growth at historical average minus one standard deviation in 2008-09

B2. Export value growth at historical average minus one standard deviation in 2008-09 3/

B3. US dollar GDP deflator at historical average minus one standard deviation in 2008-09

B4. Net non-debt creating flows at historical average minus one standard deviation in 2008-09 4/

B5. Combination of B1-B4 using one-half standard deviation shocks

B6. One-time 30 percent nominal depreciation relative to the baseline in 2008 /

Memorandum item:

Grant element assumed on residual financing (i.e., financing required above baseline) 6/

\begin{tabular}{llllllll}
\hline \multicolumn{10}{c}{ Projections } \\
\hline 2008 & 2009 & 2010 & 2011 & 2012 & 2013 & 2018 & 2028
\end{tabular}

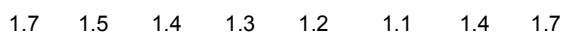

$\begin{array}{llllllll}1.7 & 1.5 & 1.3 & 1.1 & 1.0 & 0.9 & 0.6 & 0.8 \\ 1.7 & 1.5 & 1.5 & 1.4 & 1.3 & 1.3 & 1.6 & 2.2\end{array}$

$\begin{array}{llllllll}1.7 & 1.5 & 1.4 & 1.3 & 1.2 & 1.1 & 1.4 & 1.7 \\ 1.7 & 1.6 & 1.8 & 1.9 & 1.7 & 1.6 & 2.9 & 2.6 \\ 1.7 & 1.5 & 1.4 & 1.3 & 1.2 & 1.1 & 1.4 & 1.7 \\ 1.7 & 1.5 & 1.9 & 2.3 & 2.1 & 2.0 & 4.9 & 3.3 \\ 1.7 & 1.5 & 2.0 & 2.4 & 2.2 & 2.1 & 4.8 & 3.4 \\ 1.7 & 1.5 & 1.4 & 1.3 & 1.2 & 1.1 & 1.4 & 1.7\end{array}$

Sources: Fund staff projections and simulations.

1/ Variables include real GDP growth, growth of GDP deflator (in U.S. dollar terms), noninterest current account in percent of GDP, and nondebt creating flows.

$2 /$ Assumes that the interest rate on new borrowing is by 2 percentage points higher than in the baseline, while grace and maturity periods are the same as in the baseline.

3 / Exports values are assumed to remain permanently at the lower level, but the current account as a share of GDP is assumed to return to its baseline level after the shock (implicity assuming an offsetting adjustment in import levels).

4 / Includes official and private transfers and FDI.

$5 /$ Depreciation is defined as percentage decline in dollar/local currency rate, such that it never exceeds 100 percent.

6/ Applies to all stress scenarios except for A2 (less favorable financing) in which the terms on all new financing are as specified in footnote 2. 
Table 3. Honduras: Sensitivity Analysis for Key Indicators of Public Debt 2008-2028

\begin{tabular}{|c|c|c|c|c|c|c|c|c|}
\hline & & & & Project & ions & & & \\
\hline & 2008 & 2009 & 2010 & 2011 & 2012 & 2013 & 2018 & 2028 \\
\hline & & & NPV & f debt-t & D-GDP r & atio & & \\
\hline Baseline & 15.8 & 14.7 & 14.7 & 15.1 & 16.1 & 16.0 & 16.6 & 17.3 \\
\hline A. Alternative scenarios & & & & & & & & \\
\hline A1. Real GDP growth and primary balance are at historical averages & 15.8 & 14.2 & 14.0 & 14.1 & 14.5 & 13.9 & 12.0 & 9.5 \\
\hline A2. Primary balance is unchanged from 2008 & 15.8 & 14.8 & 15.0 & 15.7 & 16.6 & 16.5 & 17.1 & 17.7 \\
\hline A3. Permanently lower GDP growth $1 /$ & 15.8 & 14.9 & 15.2 & 16.1 & 17.7 & 18.4 & 24.4 & 42.5 \\
\hline B. Bound tests & & & & & & & & \\
\hline B1. Real GDP growth is at historical average minus one standard deviations in $2009-2010$ & 15.8 & 15.8 & 17.5 & 19.2 & 21.5 & 22.7 & 29.0 & 36.8 \\
\hline B2. Primary balance is at historical average minus one standard deviations in 2009-2010 & 15.8 & 15.9 & 17.4 & 17.8 & 18.7 & 18.6 & 19.0 & 18.8 \\
\hline B3. Combination of B1-B2 using one half standard deviation shocks & 15.8 & 15.3 & 16.1 & 16.5 & 17.4 & 17.2 & 17.5 & 17.5 \\
\hline B4. One-time 30 percent real depreciation in 2009 & 15.8 & 18.9 & 18.5 & 18.8 & 19.8 & 19.6 & 19.8 & 18.2 \\
\hline B5. 10 percent of GDP increase in other debt-creating flows in 2009 & 15.8 & 24.3 & 24.0 & 24.3 & 25.2 & 25.1 & 24.9 & 22.6 \\
\hline & & & PV of & ebt-to-re & evenue & atio $2 /$ & & \\
\hline Baseline & 62.5 & 58.4 & 58.3 & 59.8 & 63.7 & 63.3 & 65.6 & 68.2 \\
\hline A. Alternative scenarios & & & & & & & & \\
\hline A1. Real GDP growth and primary balance are at historical averages & 62.5 & 56.5 & 55.5 & 55.7 & 57.4 & 54.8 & 47.3 & 37.7 \\
\hline A2. Primary balance is unchanged from 2008 & 62.5 & 58.6 & 59.6 & 61.9 & 65.7 & 65.3 & 67.6 & 69.8 \\
\hline A3. Permanently lower GDP growth $1 /$ & 62.5 & 59.2 & 60.4 & 63.8 & 70.0 & 72.5 & 96.3 & 167.1 \\
\hline B. Bound tests & & & & & & & & \\
\hline B1. Real GDP growth is at historical average minus one standard deviations in $2009-2010$ & 62.5 & 62.5 & 69.1 & 75.7 & 84.7 & 89.2 & 114.5 & 145.3 \\
\hline B2. Primary balance is at historical average minus one standard deviations in 2009-2010 & 62.5 & 63.3 & 68.9 & 70.2 & 74.0 & 73.5 & 74.9 & 74.2 \\
\hline B3. Combination of B1-B2 using one half standard deviation shocks & 62.5 & 60.6 & 63.7 & 64.9 & 68.6 & 67.9 & 68.9 & 69.3 \\
\hline B4. One-time 30 percent real depreciation in 2009 & 62.5 & 75.1 & 73.6 & 74.4 & 78.1 & 77.6 & 78.2 & 71.9 \\
\hline B5. 10 percent of GDP increase in other debt-creating flows in 2009 & 62.5 & 96.3 & 95.4 & 96.1 & 99.6 & 99.0 & 98.3 & 89.2 \\
\hline & & & ebt ser & ice-to-r & evenue & atio $2 /$ & & \\
\hline Baseline & 12.5 & 12.2 & 12.9 & 12.8 & 12.8 & 12.9 & 12.5 & 13.2 \\
\hline A. Alternative scenarios & & & & & & & & \\
\hline A1. Real GDP growth and primary balance are at historical averages & 12.5 & 12.2 & 12.2 & 11.7 & 11.5 & 11.0 & 8.9 & 7.2 \\
\hline A2. Primary balance is unchanged from 2008 & 12.5 & 12.2 & 12.9 & 13.2 & 13.6 & 13.5 & 12.8 & 13.5 \\
\hline A3. Permanently lower GDP growth $1 /$ & 12.5 & 12.3 & 13.2 & 13.5 & 14.1 & 14.9 & 18.9 & 32.9 \\
\hline B. Bound tests & & & & & & & & \\
\hline B1. Real GDP growth is at historical average minus one standard deviations in $2009-2010$ & 12.5 & 12.5 & 14.4 & 16.2 & 17.8 & 19.0 & 22.0 & 28.3 \\
\hline B2. Primary balance is at historical average minus one standard deviations in $2009-2010$ & 12.5 & 12.2 & 14.5 & 16.6 & 16.2 & 15.2 & 13.5 & 14.5 \\
\hline B3. Combination of B1-B2 using one half standard deviation shocks & 12.5 & 12.4 & 13.7 & 14.5 & 14.3 & 13.9 & 12.9 & 13.4 \\
\hline B4. One-time 30 percent real depreciation in 2009 & 12.5 & 12.5 & 13.4 & 13.4 & 13.5 & 13.6 & 13.1 & 13.6 \\
\hline B5. 10 percent of GDP increase in other debt-creating flows in 2009 & 12.5 & 12.2 & 25.7 & 27.4 & 21.6 & 20.4 & 16.0 & 18.0 \\
\hline
\end{tabular}

Sources: Honduran authorities; and Fund staff estimates and projections.

1/ Assumes that real GDP growth is at baseline minus one standard deviation divided by the square root of 20 (i.e., the length of the projection period).

2/ Revenues are defined inclusive of grants. 
Table 4. Honduras: Public Sector Debt Sustainability Framework, Baseline Scenario, 2005-2028

(In percent of GDP, unless otherwise indicated)

\begin{tabular}{|c|c|c|c|c|c|c|c|c|c|c|c|c|c|c|c|}
\hline & \multicolumn{4}{|c|}{ Actual } & \multicolumn{5}{|c|}{ Estimate } & \multicolumn{5}{|c|}{ Projections } & \multirow[b]{2}{*}{ 2014-28 Average } \\
\hline & 2005 & 2006 & 2007 & $\begin{array}{r}\text { Historical } \\
\text { Average } 5 /\end{array}$ & $\begin{array}{r}\text { Standard } \\
\text { Deviation } 5 /\end{array}$ & 2008 & 2009 & 2010 & 2011 & 2012 & \multicolumn{2}{|c|}{$20132008-20013$} & 2018 & 2028 & \\
\hline Public sector debt $1 /$ & 52.8 & 35.4 & 23.7 & & & 22.5 & 22.1 & 22.2 & 22.5 & 23.2 & 22.9 & & 21.8 & 20.6 & \\
\hline $\mathrm{o} / \mathrm{w}$ foreign-currency denominated & 42.9 & 28.3 & 16.6 & & & 17.6 & 19.2 & 19.5 & 19.5 & 19.4 & 19.3 & & 17.5 & 12.4 & \\
\hline Change in public sector debt & -13.8 & -17.4 & -11.7 & & & -1.2 & -0.4 & 0.1 & 0.3 & 0.7 & -0.4 & & -0.2 & -0.1 & \\
\hline Identified debt-creating flows & -6.1 & -4.8 & -2.3 & & & -1.2 & -0.5 & 0.1 & 0.3 & 0.6 & 0.5 & & 0.2 & -0.1 & \\
\hline Primary deficit & -0.1 & 0.5 & 1.5 & 0.3 & 1.8 & 0.9 & 0.8 & 0.6 & 0.7 & 0.9 & 0.9 & 0.8 & 0.9 & 0.9 & 0.9 \\
\hline Revenue and grants & 28.2 & 24.3 & 24.1 & & & 25.2 & 25.2 & 25.2 & 25.3 & 25.3 & 25.3 & & 25.3 & 25.3 & \\
\hline of which: grants & 1.1 & 1.1 & 1.2 & & & 1.7 & 1.5 & 1.5 & 1.5 & 1.5 & 1.4 & & 1.0 & 1.0 & \\
\hline Primary (noninterest) expenditure & 28.2 & 24.8 & 25.6 & & & 26.1 & 26.0 & 25.8 & 26.0 & 26.2 & 26.2 & & 26.2 & 26.2 & \\
\hline Automatic debt dynamics & -4.7 & -4.2 & -3.5 & & & -2.0 & -1.2 & -0.5 & -0.4 & -0.3 & -0.3 & & -0.7 & -0.9 & \\
\hline Contribution from interest rate/growth differential & -4.3 & -3.7 & -2.3 & & & -1.2 & -0.9 & -0.5 & -0.5 & -0.5 & -0.5 & & -0.5 & -0.5 & \\
\hline of which: contribution from average real interest rate & -0.5 & -0.5 & -0.2 & & & -0.1 & 0.1 & 0.5 & 0.5 & 0.4 & 0.4 & & 0.4 & 0.3 & \\
\hline of which: contribution from real GDP growth & -3.8 & -3.2 & -2.1 & & & -1.1 & -1.0 & -1.0 & -0.9 & -0.9 & -0.9 & & -0.9 & -0.8 & \\
\hline Contribution from real exchange rate depreciation & -0.4 & -0.6 & -1.2 & & & -0.8 & -0.3 & 0.0 & 0.1 & 0.2 & 0.2 & & $\ldots$ & $\ldots$ & \\
\hline Other identified debt-creating flows & -1.4 & -1.1 & -0.3 & & & -0.1 & -0.1 & 0.0 & 0.0 & 0.0 & 0.0 & & 0.0 & 0.0 & \\
\hline Privatization receipts (negative) & 0.0 & 0.0 & 0.0 & & & 0.0 & 0.0 & 0.0 & 0.0 & 0.0 & 0.0 & & 0.0 & 0.0 & \\
\hline Recognition of implicit or contingent liabilities & 0.0 & 0.0 & 0.0 & & & 0.0 & 0.0 & 0.0 & 0.0 & 0.0 & 0.0 & & 0.0 & 0.0 & \\
\hline Debt relief (HIPC and other) & -1.4 & -1.1 & -0.3 & & & -0.1 & -0.1 & 0.0 & 0.0 & 0.0 & 0.0 & & 0.0 & 0.0 & \\
\hline Other (specify, e.g. bank recapitalization) & 0.0 & 0.0 & 0.0 & & & 0.0 & 0.0 & 0.0 & 0.0 & 0.0 & 0.0 & & 0.0 & 0.0 & \\
\hline Residual, including asset changes & -7.7 & -12.7 & -9.4 & & & 0.1 & 0.1 & 0.0 & 0.0 & 0.2 & -0.9 & & -0.3 & 0.0 & \\
\hline NPV of public sector debt & 9.9 & 7.0 & 17.4 & & & 15.8 & 14.7 & 14.7 & 15.1 & 16.1 & 16.0 & & 16.6 & 17.3 & \\
\hline $\mathrm{o} / \mathrm{w}$ foreign-currency denominated & 0.0 & 0.0 & 10.3 & & & 10.8 & 11.8 & 12.1 & 12.1 & 12.3 & 12.5 & & 12.3 & 9.0 & \\
\hline o/w external & $\ldots$ & $\ldots$ & 10.3 & & & 10.8 & 11.8 & 12.1 & 12.1 & 12.3 & 12.5 & & 12.3 & 9.0 & \\
\hline NPV of contingent liabilities (not included in public sector debt) & 0.0 & 0.0 & 0.0 & & & 0.0 & 0.0 & 0.0 & 0.0 & 0.0 & 0.0 & & 0.0 & 0.0 & \\
\hline Gross financing need $2 /$ & 1.4 & 1.7 & 2.3 & & & 6.7 & 5.7 & 5.6 & 5.7 & 5.9 & 6.0 & & 5.9 & 5.9 & \\
\hline NPV of public sector debt-to-revenue and grants ratio (in percent) & 34.9 & 28.8 & 72.2 & & & 62.5 & 58.4 & 58.3 & 59.8 & 63.7 & 63.3 & & 65.6 & 68.2 & \\
\hline NPV of public sector debt-to-revenue ratio (in percent) & 36.4 & 30.2 & 76.0 & & & 67.1 & 62.2 & 62.1 & 63.7 & 67.8 & 67.1 & & 68.4 & 71.1 & \\
\hline o/w external 3/ & $\ldots$ & $\ldots$ & 44.9 & & & 46.1 & 50.0 & 51.0 & 51.0 & 51.7 & 52.2 & & 50.6 & 37.0 & \\
\hline Debt service-to-revenue and grants ratio (in percent) 4 I & 6.0 & 4.9 & 3.7 & & & 12.5 & 12.2 & 12.9 & 12.8 & 12.8 & 12.9 & & 12.5 & 13.2 & \\
\hline Debt service-to-revenue ratio (in percent) $4 /$ & 6.3 & 5.1 & 3.9 & & & 13.4 & 13.0 & 13.7 & 13.6 & 13.7 & 13.7 & & 13.1 & 13.7 & \\
\hline Primary deficit that stabilizes the debt-to-GDP ratio & 13.7 & 18.0 & 13.2 & & & 2.0 & 1.2 & 0.5 & 0.3 & 0.2 & 1.2 & & 1.0 & 0.9 & \\
\hline \multicolumn{16}{|l|}{ Key macroeconomic and fiscal assumptions } \\
\hline Real GDP growth (in percent) & 6.1 & 6.4 & 6.3 & 5.2 & 1.5 & 4.8 & 4.6 & 4.5 & 4.4 & 4.2 & 4.2 & 4.5 & 4.2 & 4.2 & 4.2 \\
\hline Average nominal interest rate on forex debt (in percent) & 1.8 & 1.7 & 1.6 & 2.6 & 1.0 & 2.3 & 1.8 & 1.4 & 1.2 & 1.1 & 0.9 & 1.4 & 0.5 & 0.1 & 0.4 \\
\hline Average real interest rate on domestic currency debt (in percent) & 2.5 & 1.1 & 1.0 & -3.3 & 5.8 & -3.0 & 2.1 & 20.0 & 23.1 & 20.3 & 15.6 & 13.0 & 17.0 & 7.0 & 13.1 \\
\hline Real exchange rate depreciation (in percent, + indicates depreciation) & -0.7 & -1.4 & -4.5 & -1.8 & 4.5 & -5.1 & $\ldots$ & $\ldots$ & $\ldots$ & $\ldots$ & $\ldots$ & $\ldots$ & $\ldots$ & $\ldots$ & $\ldots$ \\
\hline Inflation rate (GDP deflator, in percent) & 7.3 & 4.8 & 7.0 & 8.5 & 5.4 & 8.8 & 7.7 & 6.7 & 6.3 & 6.1 & 5.8 & 6.9 & 5.5 & 5.5 & 5.5 \\
\hline Growth of real primary spending (deflated by GDP deflator, in percent) & 18.8 & -6.5 & 9.6 & 6.4 & 7.3 & 7.0 & 4.2 & 3.6 & 5.2 & 5.0 & 4.2 & 4.9 & 4.2 & 4.2 & 4.2 \\
\hline Grant element of new external borrowing (in percent) & 0.0 & 0.0 & 0.0 & 0.0 & 0.0 & 0.0 & 0.0 & 0.0 & 0.0 & 0.0 & 0.0 & 0.0 & 0.0 & 0.0 & $\ldots$ \\
\hline
\end{tabular}

Sources: Honduran authorities; and Fund staff estimates and projections.

1/ Debt of the general government, includes treasury bonds issued to repay arrears of ENEE.

2/ Gross financing need is defined as the primary deficit plus debt service plus the stock of short-term debt at the end of the last period.

3/ Revenues excluding grants.

4/ Debt service is defined as the sum of interest and amortization of medium and long-term debt.

5/ Historical averages and standard deviations are generally derived over the past 10 years, subject to data availability. 
Figure 1. Honduras: Indicators of Public and Publicly Guaranteed External Debt Under Alternative Scenarios, 2007-2027
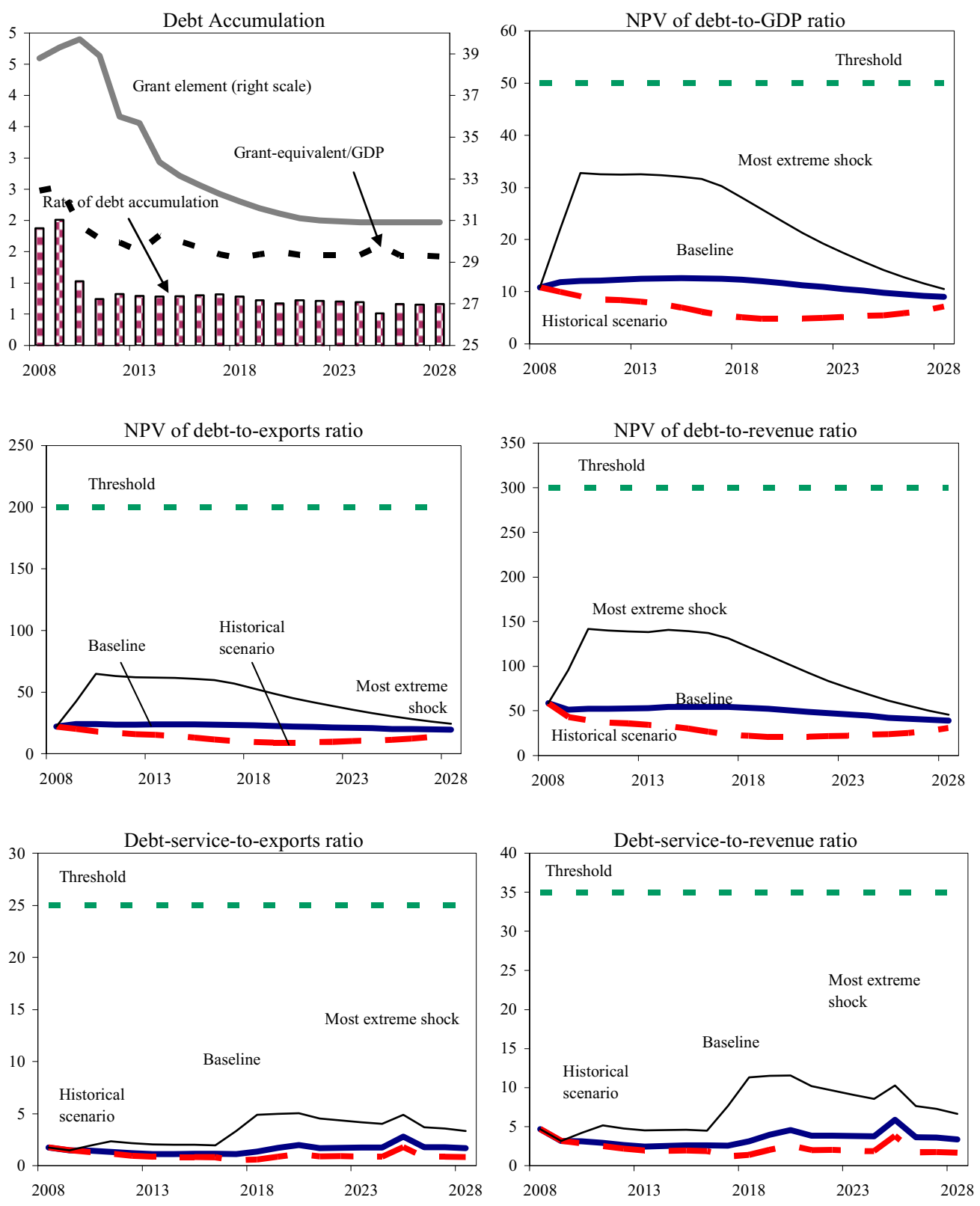

Source: Fund staff projections and simulations. 
Figure 2. Honduras: Indicators of Public Debt Under Alternative Scenarios, 2008-2028 1/
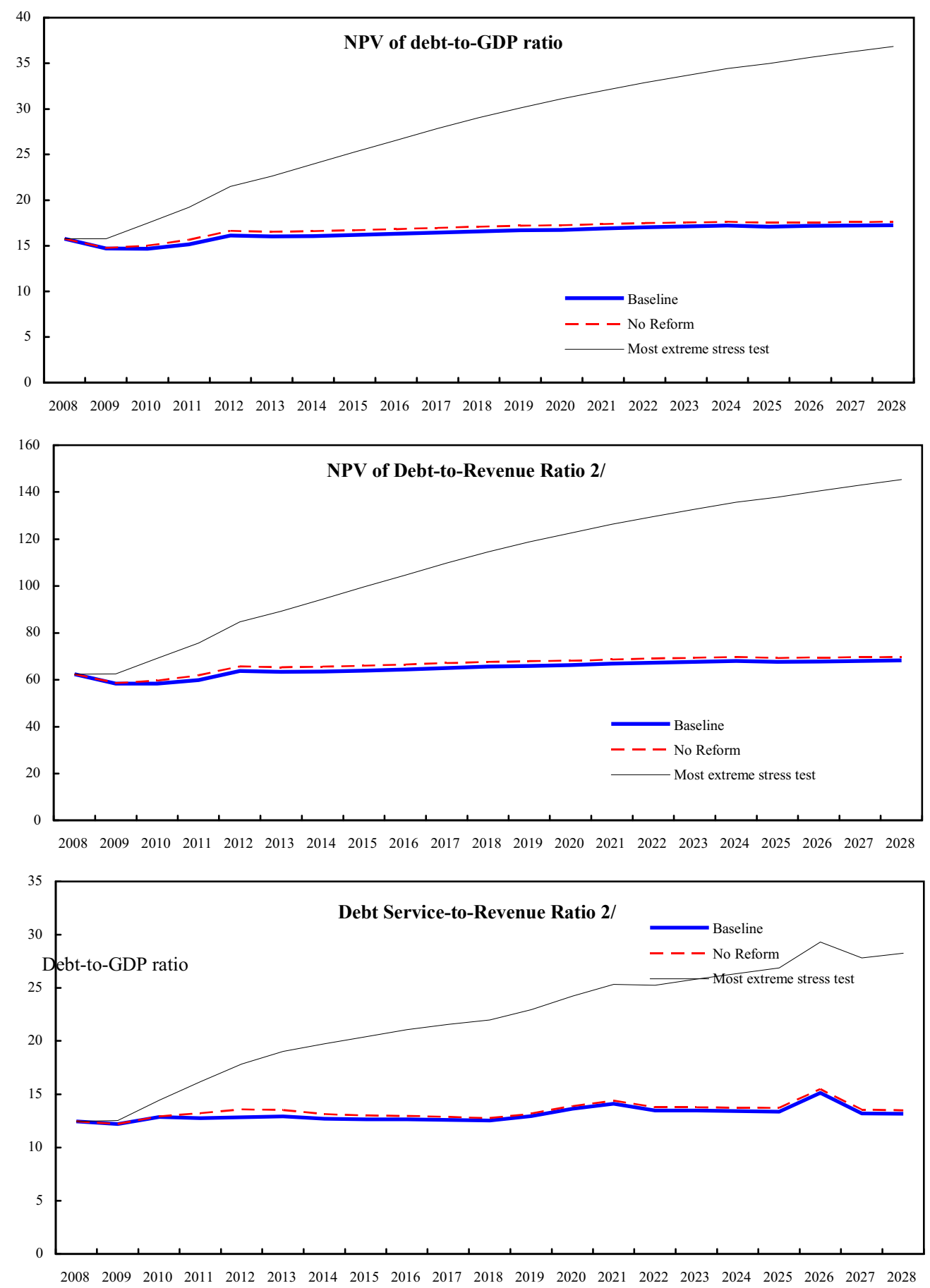

Source: Fund staff projections and simulations.

$1 /$ Most extreme stress test is test that yields highest ratio in 2018.

2/Revenue including grants. 


\section{Appendix III. Honduras-Summary of Annexes}

\section{Fund Relations}

Honduras' outstanding purchases amount to SDR 20.34 million, 15.71 percent of the quota. Honduras' de jure exchange arrangement is a crawling band, but the de facto exchange rate regime is a conventional pegged arrangement. The last Article IV consultation with Honduras was concluded on February 21, 2007. An FSAP mission was conducted in 2003 and an update was carried out in September-October 2007. The Banco Central de Honduras (BCH) was subject to an assessment completed on February 11, 2004. It identified certain weaknesses and made recommendations to which the $\mathrm{BCH}$ has responded by adopting several measures in the field of internal controls, financial reporting framework, and external auditing. An update assessment of the $\mathrm{BCH}$ safeguards framework has been recently initiated in relation to the requested new arrangement. Honduras' most recent Stand-By Arrangement expired in 1992.

\section{Relations with the World Bank Group ${ }^{4}$}

As of January 22, 2008, the IDA active portfolio in Honduras consists of 16 projects for a total commitment of US\$347.6 million; of which US\$198 million remain to be disbursed (Honduras was declared IDA-only in September 1991). The active projects are focused on infrastructure, growth to address poverty, and financial sector institutional development. Overall, the IDA expects to disburse \$93.5 million in calendar year 2008, \$144.1 million in 2009 and \$46 million in 2010, of which \$27.3 million and \$30 million in 2008 and 2009 would be in the form of fast-disbursing budget support. The current CAS covers the period 2007-2010.

\section{Relations with the Inter-American Development Bank ${ }^{5}$}

As of January 22, 2008, there were 31 projects in the Bank's loan portfolio for US\$671.3 million, with an undisbursed balance of US\$460.3 million. After the Bank Debt Relief the annual allocation for 2008 is US\$97.1 million for each year. Total MDRI debt relief from IDB to Honduras was approved on February 2007 and the debt relief amount was US\$1367 million (principal plus interest). A new country strategy is expected to be approved for the board in March 2008.

\section{Statistical Issues}

Data on the public finances, balance of payments, and external debt broadly satisfy minimum criteria required for surveillance and program monitoring purposes. However, a consistent and reliable method is needed for deriving estimates of private capital flows. Honduras has participated in the General Data Dissemination System (GDDS) since September 29, 2005.

\footnotetext{
${ }^{4}$ Adapted from text prepared by World Bank staff on January 23, 2008.

${ }^{5}$ Adapted from text prepared by IADB staff on January 8, 2007.
} 
This page intentionally left blank

(C)International Monetary Fund. Not for Redistribution 
INTERNATIONAL MONETARY FUND

HONDURAS

\section{Request for Stand-By Arrangement}

\section{Informational Annex}

Prepared by the Western Hemisphere Department (In collaboration with other departments)

Approved by David J. Robinson and Adnan Mazarei

March 24, 2008

Contents

Annexes

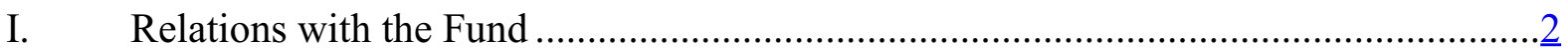

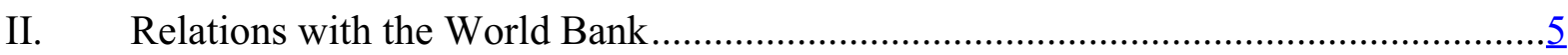

III. Relations with the Inter-American Development Bank ..........................................10

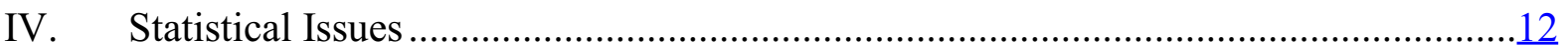




\section{Annex I. Honduras-Relations with the Fund}

(As of January 31, 2008)

I. Membership Status: Joined December 27, 1945

II. General Resources Account

SDR Million

Quota

Fund holdings of currency

Reserve position

III. SDR Department

Net cumulative allocation

Holdings
129.50

120.87

8.63

SDR Million

19.06

0.17
Percent

$$
\begin{gathered}
\text { of Quota } \\
100.00 \\
93.34 \\
6.66
\end{gathered}
$$

Percent of

Allocation

100.00

0.89

IV. Outstanding Purchases and Loans

PRGF Arrangement

SDR Million

20.34

Percent

of Quota

15.71

V. Latest Financial Arrangements

\begin{tabular}{|c|c|c|c|c|c|c|}
\hline & & \multicolumn{5}{|c|}{ Forthcoming } \\
\hline & & 2008 & 2009 & 2010 & 2011 & 2012 \\
\hline Principal & $\ldots$ & & & 1.02 & 3.05 & 4.07 \\
\hline Charges/interest & $\ldots$ & 0.71 & 0.69 & 0.69 & 0.67 & 0.65 \\
\hline Total & $\ldots$ & 0.71 & 0.69 & 1.70 & 3.73 & 4.72 \\
\hline
\end{tabular}

\begin{tabular}{lcccr}
\hline Type & $\begin{array}{c}\text { Approval } \\
\text { Date }\end{array}$ & $\begin{array}{c}\text { Expiration } \\
\text { Date }\end{array}$ & $\begin{array}{c}\text { Amount Approved } \\
\text { (SDR Million) }\end{array}$ & $\begin{array}{c}\text { Amount drawn } \\
\text { (SDR Million) }\end{array}$ \\
\hline PRGF & $02 / 27 / 2004$ & $02 / 26 / 2007$ & 71.20 & 40.68 \\
PRGF & $03 / 26 / 1999$ & $12 / 31 / 2002$ & 156.75 & 108.30 \\
PRGF & $07 / 24 / 1992$ & $07 / 24 / 1997$ & 47.46 & 33.90 \\
& & & & \\
\hline
\end{tabular}

VI. Projected Payments to Fund

(SDR million; based on existing use of resources and present holdings of SDRs): 
VII. Implementation of Enhanced HIPC Initiative: Enhanced Framework

\section{Commitment of HIPC assistance}

Decision point date

June $30,2000^{1}$

Assistance committed (NPV terms)

End-1999

Total assistance (US\$ million)

556.00

Of which: IMF assistance (US\$ million)

30.30

Completion point date

April 2005

\section{Disbursement of IMF assistance (SDR million)}

Amount disbursed

22.66

Interim assistance

Completion point balance

13.86

Additional disbursement of interest income

Total disbursements

\section{Implementation of MDRI Assistance}

$\begin{array}{lr}\text { Total Debt Relief (SDR Million) } & \\ \text { Of which: MDRI } & 107.46 \\ \text { HIPC } & 98.24 \\ \text { Debt Relief by Facility (SDR million) } & 9.21\end{array}$

\begin{tabular}{|c|c|c|c|}
\hline \multirow[b]{2}{*}{ Delivery Date } & \multicolumn{3}{|c|}{ Eligible Debt } \\
\hline & GRA & PRGF & Total \\
\hline$\overline{\text { January } 2006}$ & $\overline{\mathrm{N} / \mathrm{A}}$ & $\overline{107.46}$ & $\overline{107.46}$ \\
\hline
\end{tabular}

\section{Exchange Arrangement}

Honduras' de jure exchange arrangement is a crawling band, but the de facto exchange rate regime is a conventional pegged arrangement. The exchange rate for the lempira is determined daily in foreign exchange auctions. Banks and exchange houses must sell to the central bank 100 percent of their daily net purchases of foreign exchange at the exchange rate established the previous day. Buyers of foreign exchange (banks, exchange houses, and

\footnotetext{
${ }^{1}$ World Bank Board, July 6, 2000.

${ }^{2}$ The Multilateral Debt Relief Initiative (MDRI) provides 100 percent debt relief to eligible member countries that are qualified for the assistance. Grant assistance from the MDRI Trust and HIPC resources provide debt relief to cover the full stock of debt owed to the Fund as of end-2004 that remains outstanding at the time the member qualifies for such debt relief.
} 
private individuals) bid at a price that cannot differ by more than 7 percent from the base exchange rate, in either direction. The base exchange rate is adjusted every five auctions in accordance with the anticipated inflation differential between Honduras and its major trading partners, the changes in the exchange rates of currencies of trading partners of Honduras with respect to the U.S. dollar and the level of the CBH's net international reserves. The official bid exchange rate on December 31, 2007 was L18.90 per U.S. dollar.

Honduras has accepted the obligations under Article VIII, Section 2, 3, and 4 of the Articles of Agreement, and maintains a system that is free of restrictions on the making of payments and transfers for current international transactions.

\section{Article IV Consultation}

The last Article IV consultation with Honduras was concluded on February 21, 2007. It is proposed that the next Article IV consultation with Honduras be held in accordance with the July 15, 2002 decision on consultation cycles.

\section{FSAP Participation and ROSCs}

Fiscal ROSC conducted on February 26-March 2, 2001 (IMF Country Report No. 02/16) and updated (IMF Country Report No. 05/256).

FSAP conducted on October 14-19, 2002 and January 20-February 4, 2003.

Data ROSC data conducted on July 8-24, 2003 (IMF Country Report No. 05/230).

FSAP Update conducted on September 24 to October 9, 2007.

\section{Safeguards Assessments}

Under the Fund's safeguards assessment policy, Banco Central de Honduras (BCH) was subject to an assessment with respect to the PRGF arrangement approved in February 2004. The assessment, completed on February 11, 2004, identified certain weaknesses and made recommendations, implementation of which has been monitored by staff. Consequently the $\mathrm{BCH}$ has strengthened its safeguards framework through: (i) the appointment of an international audit firm, that complies with International Standards on Auditing;

(ii) publication of the bank's audited financial statements; and (iii) establishment of an Audit Committee. Several vulnerabilities remain, however, in the area of the BCH's legal framework and its internal controls. An update assessment of the BCH safeguards framework has been recently initiated in relation to the requested new arrangement. 


\section{Annex II: Honduras-Relations with the World Bank}

(As of January 23, 2008)

\section{Partnership in Honduras' Development Strategy}

1. Honduras' Poverty Reduction Strategy Paper (PRSP), which was completed in October 2001 and endorsed by the Boards of the World Bank and IMF, has placed poverty reduction at the center of the government's development agenda. The main objective of the strategy is to reduce poverty by 24 percentage points over the period 2001-15. The strategy itself is structured around six pillars as follows: (i) accelerating equitable and sustainable growth to levels consistent with the income poverty reduction targets; (ii) reducing rural poverty; (iii) reducing urban poverty; (iv) enhancing investment in human capital; (v) strengthening social protection for specific vulnerable groups; and (vi) ensuring the sustainability of the strategy through governance and institutional reforms and enhanced environmental sustainability. The authorities presented a Second Annual PRSP Progress Report to the Boards of the World Bank and Fund in March 2005. The Third and the Fourth Annual PRS Progress Reports were presented to the Boards of the World Bank and IMF on July 17, 2007. A revised PRSP is currently under preparation.

2. The Government of Honduras reached the Completion Point under the Highly Indebted Poor Country (HIPC) Initiative in March 2005. Implementation of the PRSP program, a fundamental condition for reaching this Point, requires active participation of the government, civil society, and donors. In this context, the Fund and World Bank have been cooperating closely within their respective mandates - and will continue doing so - in assisting the government to implement its poverty reduction and economic growth strategy and the related reform agenda. The Fund leads the policy dialogue on macroeconomic issues (i.e., fiscal, monetary, and exchange rate policy), while the World Bank leads the policy dialogue on poverty reduction, governance, public sector management, and sectoral structural reforms (in areas including energy reform, telecommunications, social sectors, land regularization, environment, competitiveness, and judicial reform).

\section{Bank Group Assistance Strategy}

3. The World Bank's current Country Assistance Strategy (CAS) was prepared in October 2006, and is fully aligned with the six pillars of the Honduras' Poverty Reduction Strategy. The core goal of that CAS, based on the PRSP as the guiding framework for external assistance, focuses on removing the constraints to economic growth identified in recent Bank analytical work. However, it also contains a narrower focus on fewer priority areas and plans for the transition to Honduras' eventual graduation from IDA borrowing.

4. As of January 22, 2008, the IDA active portfolio in Honduras consists of 16 projects for a total commitment of US\$347.6 million; of which US\$198 million remains to be 
disbursed (Honduras was declared IDA-only in September 1991). The active projects work in the following areas: (a) rural poverty and human resource development (reform of the rural access through a Health System Reform Project, support to indigenous groups through the Nuestras Raices Project and a Nutrition and Social Protection which focus on the job market for the youth); (b) transport and infrastructure (Water and Sanitation Project - PROMOSAS which supports decentralization water and sanitation services, a Rural Infrastructure Project to develop decentralized infrastructure for electricity, water, sanitation, and roads, and Barrio Ciudad that works in urban upgrading); (c) natural resource management and environment (Regional Development in the Copan Valley, a Land Administration Program, and a Forest and Rural Productivity project); (d) public sector and economic management (Judicial Branch Modernization that seeks to increase access to justice for the poor, Financial Sector Technical Assistance Credit, a Poverty Reduction Strategy Technical Assistance Credit); (e) disaster preparedness consists of a Disaster Management Credit; and (f) investment climate improvement and private sector participation (Trade Facilitation and Productivity Enhancement Credit).

5. In addition, a fast-disbursing First Programmatic Financial Sector Development Policy Credit (US\$25 million) was also approved early in 2005 from the previous CAS and will support financial sector institutional development, and it is pending the disbursement of the second tranche. In the pipeline for calendar year 2008 the following operations are under preparation: budget support credit (US\$20 million), the Rural Competitiveness Project (US\$30million), Road Reconstruction and Improvement (\$30 million), and Utility Restructuring (\$30 million). Overall, the IDA expects to disburse $\$ 93.5$ million in calendar year 2008, \$144.1 million in 2009 and $\$ 46$ million in 2010, of which \$32-\$34 million in 2008 would be in the form of fast-disbursing budget support.

6. In addition to the above operations, the Bank has approved a $\$ 12$ million grant under the Global Environment Facility (GEF) in May 2006, for the protection of the Corazn Transboundary Biosphere Reserve Project.

7. The current CAS covers the period 2007-2010. The consultations with the new Honduran government have emphasized four strategic areas of collaboration: (i) maintaining a stable macroeconomic framework; (ii) improving the quality of education; (iii) addressing the energy crisis - including the restructuring of ENEE and attraction of new investment into the sector; and (iv) modernizing the state - with special emphasis on the professionalization of the civil service and implementation of the Transparency and Access to Information Law.

8. With regard to economic and sector work, the new CAS includes two types of activities. The first set includes core diagnostic analyses, which are country-specific and address important cross-cutting issues, including a deepened understanding of poverty, growth, public expenditures, and fiduciary issues. This includes the Public Expenditure Review, an Energy Strategy Study, an FSAP update and a ROSC Study for the current fiscal year, which have all been delivered, and a Country Environmental Assessment and 
Institutional and Governance Assessment to be delivered. A Public Expenditure Tracking Survey is in preparation. The second group of activities are region-wide or sub-regional in scope, focusing on topics and themes relevant to several countries but including sufficient country-specificity to further Honduras' development agenda and support the design of lending operations. This includes sector studies on energy, decentralization, disaster mitigation, financial sector, and service delivery.

\section{IMF-World Bank Collaboration in Specific Areas}

9. Fund and Bank staffs have maintained a close working relationship, especially with respect to: (i) the PRSP, its subsequent updates and joint assessments; (ii) the HIPC and Multilateral Debt Relief (MDRI) initiatives; (iii) financial sector reform; (iv) energy sector reform; (v) public expenditure monitoring; and (vi) the preparation of Debt Sustainability Analyses (DSAs). The World Bank and IMF Resident Representatives routinely consult, exchange data and information and coordinate with each other on major public policy matters, and Bank staffs have participated in the Fund's PRGF missions.

- $\quad$ Poverty Reduction Strategy Paper Progress Reports (PRSP). The Fund and Bank supported the government in the preparation of the PRSP, completed in August 2001, and continued to follow its implementation. The first Progress Report (PR) was completed in December 2003, the second PR was approved in March 2005, and the third and fourth in July 2007. The Bank and Fund collaborated in the production of Joint Staff Assessments, which accompanied the presentation of the PRSP and PRSP Progress Reports to their respective Boards.

- HIPC and MDRI Initiatives. The Fund and Bank jointly tracked the status of floating completion point conditions established under the Enhanced HIPC Initiative. Further progress in structural and social reforms continue to be monitored, including measures in the areas of governance and transparency, social security system reform, provision of basic health services for the poor, quality of education, safety nets, and financial system reform. Also, in early 2006 the Fund and Bank completed an assessment of Honduras' eligibility for debt relief under the MDRI, which reviewed the country's performance since the HIPC completion point in the areas of macroeconomic management, implementation of a poverty reducing strategy and public expenditure and fiduciary management.

- Financial Sector. The Fund and the Bank continue to assist the government in these issues through a comprehensive technical assistance program. A joint Fund-Bank FSAP update mission took place in September/October 2007 under this program. The Fund and the Bank co-managed the preparation of the 2003 Honduras Financial Sector Assessment Program (FSAP). Based on the FSAP, the government embarked on a comprehensive financial system reform that aims at strengthening the regulatory 
framework and ongoing supervision, enhancing the efficiency of the financial safety net, and improving mechanisms for anti-money laundering and financing of terrorism.

- $\quad$ Energy Sector Reform. As previously mentioned, the Bank presented a diagnostic study of the energy sector in April 2007. This study has been the focal point for interagency (including the IMF) dialogue with the authorities over energy reform.

- $\quad$ Public Expenditure Monitoring. The Fund and Bank are continuously monitoring the trends in public spending. The Bank is publishing a public expenditure review in January 2008 and will follow-up with a PER update in 2009. Particular attention is paid to limiting the unsustainable growth in the public sector wage bill and improving the operating balance of state enterprises.

- Debt Sustainability Analyses. The Fund and Bank completed their first joint DSA under the new LIC-DSA framework in September 2006, providing important analytic underpinnings for the Bank's new CAS. 
Financial Relations with the World Bank Group (In millions of U.S. dollars)

A. Active IDA Operations (As of January 22, 2008) 1/

IDA projects

1 Community-Based Education Project

2 Financial Sector Technical Assistance

3 Health System Reform Project

4 Land Administration Program

5 Emergency Disaster Mitigation

6 Forests and Rural Productivity

7 Trade Facilitation and Productivity Enhancement

8 Regional Development in the Copan Valley

9 Judicial Branch Modernization

10 Nutrition and Social Protection

11 Nuestras Raices Program

1st Programmatic Financial Sector Development

12 Policy Credit

13 Poverty Reduction Strategy Technical Assistance

14 Rural Infrastructure Project

15 Barrio-Ciudad Project

16 Water and Sanitation Project
Commitment

41.5

9.9

27.1

25.0

9.0

20.0

28.1

12.0

15.0

20.0

15.0

25.0

8.0

47.0

15.0

30.0
Undisbursed

0.0

7.4

8.1

4.2

8.3

7.5

18.0

2.0

13.3

17.0

3.6

12.8

4.5

44.9

14.3

31.3
Total IDA/IBRD Contribution

IDA

IBRD
Disbursed

$1,477.8$

691.0

2,205.6
Undisbursed

198.5

0.0

198.5

TOTAL

B. IBRD/IDA Loan disbursements

(Calendar Year)

$\begin{array}{lccccccccc}\text { Gross } & \mathbf{1 9 9 9} & \mathbf{2 0 0 0} & \mathbf{2 0 0 1} & \mathbf{2 0 0 2} & \mathbf{2 0 0 3} & \mathbf{2 0 0 4} & \mathbf{2 0 0 5} & \mathbf{2 0 0 6} & \mathbf{2 0 0 7} \\ \begin{array}{l}\text { disbursements } \\ \begin{array}{l}\text { Amortization } \\ \text { (cash) }\end{array}\end{array} & 273.0 & 38.2 & 98.0 & 88.2 & 44.5 & 125.0 & 151.3 & 57.6 & 45.6 \\ \begin{array}{l}\text { Net } \\ \text { disbursements }\end{array} & 49.0 & 35.2 & 27.3 & 28.2 & 29.3 & 26.6 & 81.9 & 7.7 & 0.0 \\ & 224.0 & 3.1 & 70.7 & 60.1 & 15.2 & 98.4 & 69.3 & 49.9 & 45.6\end{array}$

Source: World Bank estimates.

1 / Net of cancellations. 
Annex III. Honduras-Relations with the Inter-American Development Bank (As of February 28, 2008)

A. Statement of IDB Loans

(in millions of U.S. dollars)

\begin{tabular}{|c|c|c|c|}
\hline Year & Purpose & Status & Amount \\
\hline 2004 & Financial sector program & Approved & 25.0 \\
\hline 2004 & Poverty Reduction Sector Program & Approved & 30.0 \\
\hline 2004 & $\begin{array}{l}\text { Improvement of the PPP Atlantic Corridor (Sections of } \\
\text { the CA- } 5 \text { Norte Highway) }\end{array}$ & Approved & 50.0 \\
\hline 2004 & Middle Education and Labor Program & Approved & 30.6 \\
\hline 2004 & Strengthening of Fiscal Management & Approved & 15.0 \\
\hline 2004 & Municipal Development Program Tegucigalpa II & Approved & 22.5 \\
\hline 2004 & Social Protection Program & Approved & 20.0 \\
\hline 2004 & $\begin{array}{l}\text { PPP support to rural electrification and to the energy } \\
\text { sector }\end{array}$ & Approved & 35.0 \\
\hline 2005 & Improvement of Health Conditions in Honduras & Approved & 16.6 \\
\hline 2005 & National Sustainable Tourism Program & Approved & 35.0 \\
\hline 2005 & Comprehensive Development Autochthonous People & Approved & 11.1 \\
\hline 2006 & Fiscal Reform (Policy-based loan) & Approved & 30.0 \\
\hline 2006 & Sanitation and Water Investment Complementary & Approved & 30.0 \\
\hline 2006 & Housing Program & Approved & 30.0 \\
\hline \multirow[t]{2}{*}{2006} & $\begin{array}{l}\text { Sectorial-Social Program Associated to the ERP (Policy- } \\
\text { based loan) }\end{array}$ & Approved & 30.0 \\
\hline & Approved Total 2004-2006 & & 410.8 \\
\hline 2007 & $\begin{array}{l}\text { Multiphase Program of Road Rehabilitation in Sections of } \\
\text { the PPP Touristy Corridor }\end{array}$ & Approved & 40.0 \\
\hline 2007 & $\begin{array}{l}\text { Supplemental Financing Improvement PPP Atlantic } \\
\text { Corridor }\end{array}$ & Approved & 30.0 \\
\hline \multirow[t]{2}{*}{2007} & Rural Business Development Program (PRONEGOCIOS) & Approved & 27.1 \\
\hline & Approved Total 2007 & & 97.1 \\
\hline 2008 & Support for Public Finances and Municipal Management & & 28.6 \\
\hline 2008 & Support Energy Sector II Program & & 48.6 \\
\hline \multirow[t]{2}{*}{2008} & Logśtica Corredor Infrastructure Program & & 20.0 \\
\hline & Pipeline Total 2008 & & 97.1 \\
\hline
\end{tabular}




\section{B. Operations (as of February 28, 2008)}

\begin{tabular}{|c|c|c|c|c|c|c|c|}
\hline \multirow{2}{*}{\multicolumn{2}{|c|}{ Credit and Multisectoral Preinvestment }} & \multicolumn{2}{|c|}{ Approved } & \multicolumn{2}{|c|}{ Disbursed } & \multicolumn{2}{|c|}{ Undisburse } \\
\hline & & \multicolumn{2}{|c|}{12.0} & \multicolumn{2}{|c|}{11.6} & \multicolumn{2}{|c|}{0.4} \\
\hline \multicolumn{2}{|c|}{ Agriculture and Rural Development } & \multicolumn{2}{|c|}{35.3} & \multicolumn{2}{|l|}{33.2} & \multicolumn{2}{|c|}{2.1} \\
\hline \multicolumn{2}{|c|}{ Urban Development and Housing } & \multicolumn{2}{|c|}{30.0} & \multicolumn{2}{|l|}{29.9} & \multicolumn{2}{|c|}{0.12} \\
\hline \multicolumn{2}{|c|}{ Education } & \multicolumn{2}{|c|}{43.6} & \multicolumn{2}{|l|}{10.1} & \multicolumn{2}{|c|}{33.5} \\
\hline \multicolumn{2}{|l|}{ Energy } & \multicolumn{2}{|c|}{65.0} & \multicolumn{2}{|l|}{13.5} & \multicolumn{2}{|c|}{51.5} \\
\hline \multicolumn{2}{|l|}{ Social Investment } & \multicolumn{2}{|c|}{113.9} & \multicolumn{2}{|l|}{28.5} & \multicolumn{2}{|c|}{85.4} \\
\hline \multicolumn{2}{|l|}{ Private Sector Development } & \multicolumn{2}{|c|}{10.0} & \multicolumn{2}{|l|}{8.6} & \multicolumn{2}{|c|}{1.4} \\
\hline \multicolumn{8}{|l|}{ Environment and Natural } \\
\hline \multicolumn{2}{|l|}{ Disasters } & 40.3 & & 1.4 & & & \\
\hline State Reform and Moderniz & & 93.6 & & 52.0 & & & \\
\hline Health & & 16.6 & & 3.4 & & & \\
\hline Sanitation & & 56.0 & & 4.4 & & & \\
\hline Transportation & & 120 & & 6.9 & & & \\
\hline Tourism & & 35.0 & & 7.4 & & & \\
\hline Total & & 671 & & 210. & & & \\
\hline & C. I & Jet Flov & f Resot & ces & & & \\
\hline & 2001 & 2002 & 2003 & 2004 & 2005 & 2006 & 2007 \\
\hline Disbursements & 103.8 & 47.7 & 89.7 & 138.3 & 64.9 & 91.6 & 90.0 \\
\hline Amortization $^{3}$ & 24.4 & 28.5 & 44.8 & 44.0 & 32.2 & 32.3 & 54.7 \\
\hline Net flow of resources & 79.4 & 19.2 & 44.9 & 94.3 & 32.7 & 59.4 & 25.0 \\
\hline Commitments made & 68.1 & 81.8 & 82.5 & 228.1 & 62.7 & 117.9 & 95.0 \\
\hline Undisbursed commitments & 353.9 & 389.2 & 380.5 & 480.6 & 478.4 & 511.8 & 438.6 \\
\hline
\end{tabular}

\section{IADB Loan Commitments and Disbursements}

As of January 22, 2008, there were 31 projects in the Bank's loan portfolio for US\$671.3 million, with an undisbursed balance of US\$460.3 million. After the Bank Debt Relief the annual allocation for 2008 is US\$97.1 millions for each year. Total MDRI debt relief from IDB to Honduras was approved on February 2007 and the debt relief amount was US\$1367 million (principal plus interest). A new country strategy is expected to be approved for the board in March 2008.

\footnotetext{
${ }^{3}$ It does not include HIPC.
} 


\section{Annex IV. Honduras-Statistical Issues}

\section{Introduction}

1. Data on the public finances, balance of payments, and external debt broadly satisfy minimum criteria required for surveillance and program monitoring purposes. However, a consistent and reliable method is needed for deriving estimates of private capital flows. Honduras participates in the General Data Dissemination System (GDDS). A Report on the Observance of Standards and Codes - Data Module, Response by the Authorities, and Detailed Assessments Using the Data Quality Assessment Framework were published on the IMF website in July 2005.

\section{Real Sector and Prices}

2. The Central Bank of Honduras $(\mathrm{BCH})$ recently released a revised set of national accounts estimates for 2000-06 consistent with System of National Accounts 1993, rev. 4. The base year was revised to 2000 with the new GDP estimates about 20 percent higher than the old series. Preparatory work is underway to produce quarterly estimates fully consistent with the new annual series following a STA quarterly national accounts technical assistance mission in February 2008. The BCH is also developing social accounting and input-output matrices.

3. The BCH prepares and publishes (since April 2000) the consumer price index (CPI), with reference period December $1999=100$. The selection of products included in the CPI basket and corresponding weights are based on the expenditure data reported by households in the 1998-99 National Survey on Household Income and Expenditure.

\section{Monetary Accounts}

4. The $\mathrm{BCH}$ is currently participating in the Regional Project for the Harmonization of Monetary and Financial Statistics (MFS) in Central America and the Dominican Republic. New MFS have been compiled using improved data sources (particularly for the allocation of counterpart sectors to financial instruments in the balance sheets of banks and other depository corporations) and the framework of the standardized report forms (SRFs). Followup work will continue, in the context of the regional project, aiming at producing regionally harmonized monetary and financial statistics.

5. In addition to the work on SRFs, a mission in June 2007 assisted the authorities in establishing an integrated monetary database from which alternative and consistent presentations of MFS can be derived to meet the data needs of the authorities, WHD, and STA. 


\section{Balance of Payments}

6. In November 2007, the BCH disseminated for the first time balance of payments and international investment position (IIP) statistics in broad conformity with the fifth edition of the IMF Balance of Payment Manual (BPM5). Balance of payments data (annual for 20002006 and quarterly for 2004-2007Q3) and IIP data (2004-2006) are available at the BCH website. The BCH has not yet reported these new data to STA for inclusion in Fund's publications. Honduras is one of the fourteen low-income countries (LICs) that agreed to participate in the joint IMF-World Bank Project to extend the Quarterly External Debt Statistics (QEDS) database to GDDS participants launched in February 2008. To this end, the $\mathrm{BCH}$ reported quarterly data on public and publicly-guaranteed external debt to the World Bank from 2002 Q4 onwards.

\section{Government Finance}

7. The Ministry of Finance (SEFIN) compiles and disseminates government finance statistics (GFS) covering central administration, central government, general government, and nonfinancial public sectors. The above-the-line data of these sectors are reported to the Western Hemisphere Department (WHD). The BCH compiles below-the-line data for central administration and nonfinancial public sector and reports these data to the WHD.

8. The SEFIN has reported GFS data (budgetary central government) to STA for publication in the 2007 Government Finance Statistics Yearbook (GFSY). No data were reported for International Financial Statistics (IFS).

9. A GFS pilot study mission (October 2006) found that the authorities have taken steps to implement the GFSM 2001 framework. These steps include adjustments to the current methodology incorporating some definitions and concepts of the GFSM 2001, and introduction of a GFS module in the Integrated Financial System (SIAFI). However, there remain revenue and expenditure classification issues regarding alignment with international practices. The mission also found that the broader institutional coverage of the financing data does not allow proper reconciliation with the above-the-line data. 
This page intentionally left blank

(C)International Monetary Fund. Not for Redistribution 


\section{Statement by the IMF Staff Representative}

April 7, 2008

1. This statement updates on developments since the preparation of the staff report. The additional information does not change the thrust of the staff appraisal.

2. All prior actions for approval of the Stand-By Arrangement have been completed:

- $\quad$ The 2008 budget was approved by Congress on April 2, 2008, and is consistent with the policies discussed in the staff report.

- $\quad$ The end-March floor on net international reserves was met, with a margin of US\$6 million. The indicative ceiling on net domestic assets was also observed by a margin of L420 million, partly reflecting larger-than-anticipated accumulation of government deposits.

- $\quad$ The monetary tightening through increasing obligatory investments and sales of central bank bills (equivalent to 2 percentage points of reserves requirements) was met on April 3. Preliminary data suggests this prior action was met with a significant margin (about 15 percent).

3. The authorities have also implemented a prudential measure envisaged under the program. On March 25, regulations to tighten loan classification and provisioning were issued to help banks internalize the risks associated with the rapid expansion of bank credit. 
This page intentionally left blank

(C)International Monetary Fund. Not for Redistribution 


\section{Statement by José Rojas, Executive Director for Honduras and Alvaro Umaňa, Senior Advisor to Executive Director April 7, 2008}

The Honduran economy has performed well in the past few years in terms of both growth and stability, despite a previous history of low growth and volatility. Growth surpassed 6 percent of GDP on average during the last four years, inflation has been kept in one digit, the fiscal deficit has been manageable, international reserves increased and foreign investment has been dynamic. At the same time, debt relief obtained from the Enhanced HIPC, the MDRI and the IADB have allowed to bring the external debt down from 60 percent of GDP in 2004 to 16 percent in 2007. The combination of growth and reduced indebtedness also freed the Honduran government to devote significant resources to education and poverty reduction. Over 80 percent of debt relief resources were devoted to education and health. Although the absolute level of poverty remains high, overall poverty has been reduced by 6 percent and extreme poverty by 11 percent in the last two years.

The Honduran economy is particularly vulnerable to external shocks, ranging from hurricanes to terms-of-trade fluctuations and heavy reliance on imported oil for power generation. Over the past year, a number of imbalances have started to develop. Inflation increased to near 9 percent last December. As in many other developing countries, inflation was boosted by increases in food and oil prices. Bank credit expanded rapidly and led to imports increases and a weakening of the external current account deficit. Imbalances in the energy sector also contributed to the overall problem.

Our Honduran authorities seek support for a precautionary, 12-month SBA in the amount of 38.85 million SDR (30 percent of the quota) that will help them anchor economic policy ahead of the primary elections later this year, as well as to provide a bridge for a PRGF before the end of 2008. The program seeks to correct the economic imbalances that have developed and it is centered on strengthening macro stability through policies in key areas. On the fiscal front the program is ambitious and it seeks to reduce the overall fiscal deficit from $2 \frac{1}{4}$ percent in 2007 to $1 \frac{1}{2}$ percent in2008. The program also seeks to maintain inflation in single digits, to reverse the widening account deficit, to bring credit expansion to a sustainable basis and to promote exchange rate flexibility. The program also seeks to restore the financial soundness of the energy sector.

The previous PRGF, approved in 2004, focused on fiscal consolidation and structural reforms to support growth and reduce vulnerabilities in the financial sector, which was considerably strengthened in its legal, prudential and supervisory frameworks. Medium-term reforms were geared at strengthening the central bank and monetary policy operations, the banking commission (CNBS) and the tax administration office (DEI). Debt relief support, mentioned above and amounting to over US\$ 3 billion, was also a key element but it raised expectations for higher spending. The program achieved important goals and was partially successful.

The new government took over in early 2006 with a strong commitment to reduce poverty, as well as to maintain social and macroeconomic stability, in spite of record-levels oil prices 
and rising food prices. Wage pressures and the need to protect the most vulnerable groups contributed to the imbalances that developed, and the government started to take measures to correct them.

On the fiscal front, although the deficit rose, real progress has been made and tax revenues have increased considerably. On the monetary side, expansionary policies and the entry of foreign banks led to competition for market share, and a rise in credit of 30 percent and prudential measures to guarantee sustainable growth have already been taken. The central bank raised policy interest rates to 7.75 percent in February 2008 and increased reserve requirements.

The real exchange rate is near its long-term equilibrium and it has remained stable in the last two years, although the official regime allows the Lempira to fluctuate in a 7 percent band. The exchange rate policy will be managed to maintain external competitiveness. Net international reserves (NIR) fell by $\$ 100$ million in 2007 , although their level is still adequate to cover four months of non-maquila imports. They are expected to recover throughout the program.

The program proposed for 2008 aims at supporting conditions for sustained growth and poverty reduction through policies in three key areas: a tightening of fiscal policy and stabilization of the wage bill, monetary policy geared to containing inflation and recovering NIR, while bringing credit down to sustainable levels. The exchange rate policy will utilize more actively the existing system to support monetary policy.

In the energy sector a key imbalance was caused by losses in ENEE, the national electricity enterprise, which also accumulated arrears to private generators and contractors. It is worth noting that the Honduran government has already reacted and electricity rates were increased by 16 percent in January, and a new tariff structure will come into effect this month with an additional 11 percent increase. The energy sector will be strengthened with support of the World Bank and IADB, and electricity rate increases will cover ENEE operational costs and arrears with private generators.

In contrast to previous years, the 2008 budget is expected to have a higher degree of financing by concessional external lending, allowing for sharply reduced net domestic financing. A new key source of financing is provided by Venezuela through Petrocaribe, which is expected to yield US\$ 350 million in 2008-09, with US\$ 80 million in 2008 for investment in hydroelectric projects, and to improve electricity transmission and distribution to reduce losses. This is critical to correct the present heavy dependence on fossil fuels for generation in the power sector.

To ensure that the resources provided by Petrocaribe are used in a transparent manner and for infrastructure only, a trust fund has been set up in the central bank, and periodic reports 
will be presented to a blue ribbon panel with civil society representatives created for this purpose. The government also intends to use the one-time proceeds for the sale of a mobile phone band, equivalent to 0.6 percent of GDP, to finance already budgeted investments in infrastructure projects, mostly roads.

Risks include a less-favorable external environment, primarily related to the downturn of the US economy, as well as expansionary policies ahead of the primary elections later this year. The deceleration in the US economy is expected to lead to a slowdown in the Honduran economy. It is also expected that remittances will also be affected. In addition to these, there is the concern about the level of oil prices, given the electrical sector's reliance on fossil fuels.

Honduras' debt outlook is positive and the debt ratios should remain below their indicative thresholds and resilient to shocks over the medium and long term. This is due to the low initial ratios, product of debt relief and the consolidation of macro stability. Public debt should continue on a sustainable path, even under the most extreme test.

The government is fully committed to its growth and poverty reduction agenda and its continuing to update and refine its medium-term policies for poverty alleviation and growth. In coming months, it plans to finalize a program, including and updated PRSP, that could be supported under the Poverty Reduction and Growth Facility.

It is important to note that the 2008 budget was approved by Congress on the terms accorded with the Fund on April 2. Prior actions related to the policy interest rate, NIR and NDA of the Central Bank were also fulfilled at the end of March. The last prior action related to open market operations was fulfilled on April 3. These actions reflect the strong commitment of the government to this program. Our Honduran authorities seek support for this Stand-By Arrangement from the Executive Directors to regain mometum in the structural reform process and to anchor economic policy in this critical year. This SBA would also serve as a bridge to a PRGF that would be presented later this year. 
This page intentionally left blank

(C)International Monetary Fund. Not for Redistribution 
Press Release No. 08/76

FOR IMMEDIATE RELEASE

April 8, 2008
International Monetary Fund

Washington, D.C. 20431 USA

\section{IMF Executive Board Approves an Stand-By Arrangement for Honduras}

The Executive Board of the International Monetary Fund (IMF) approved yesterday a 12month Stand-By Arrangement for Honduras for SDR 38.8 million (about US\$63.5 million) to support the country's economic program for 2008. The authorities intend to treat the arrangement as precautionary. The main objective of the authorities' program is to entrench macroeconomic stability and sustain high growth by consolidating and reorienting the fiscal stance, containing inflation, reinforcing external stability, and addressing weaknesses in the energy sector.

Following the Executive Board discussion, Murilo Portugal, Deputy Managing Director and Acting Chair, said:

"The Honduran economy has posted robust growth and declining poverty in recent years. Nevertheless, given that internal and external economic imbalances have developed, and to support prospects for continued growth and poverty reduction, the authorities' program appropriately strengthens the policy framework to reinforce macroeconomic stability and place the energy sector on a stronger financial footing.

"The authorities' fiscal policy aims at a stable debt/GDP ratio and a reorientation of public spending toward priority investment, while reducing the fiscal deficit. On the revenue side, tax administration is being strengthened and electricity tariffs raised. On the expenditure side, the program envisages strict control of current spending, targeting energy subsidies to protect the poor, and limiting net lending by the public pension funds to protect their financial integrity. A central element of the authorities' program is the stabilization, and subsequent reduction, of the public wage bill as a percentage of GDP.

"Monetary policy is aimed at containing inflation in single-digits, bringing bank credit growth to more sustainable levels, and ensuring the build-up of international reserves to maintain coverage relative to 2007. The authorities have already taken actions to tighten monetary policy, and are committed to further tightening as necessary to reach the program

Washington, D.C. 20431 • Telephone 202-623-7100 • Fax 202-623-6772 • www.imf.org 
targets. Prudential policies are designed to strengthen the resilience of the banking system while introducing forward looking risk-based supervision.

"The central bank has started to use exchange rate policy more actively within the current framework to safeguard external competitiveness and help protect the economy against external shocks.

"A centerpiece of the program is to strengthen the energy sector to support growth and safeguard public finances. In this context, electricity tariffs have already been increased. The program envisages the clearance of arrears with electricity suppliers, and the implementation of a new tariff structure that covers operational costs of the electricity company.

“The precautionary Stand-By Arrangement will support the authorities' economic program and provide a bridge to a new medium-term program that could be supported under the IMF's Poverty Reduction and Growth Facility (PRGF) later in the year," Mr. Portugal said.

ANNEX

\section{Recent Economic Developments}

Honduras has had three previous Poverty Reduction and Growth Facility (PRGF) arrangements, the last of which ended in February 2007. The most recent PRGF program focused on fiscal consolidation and structural reforms to strengthen growth prospects and reduce vulnerabilities in the financial sector.

Over the last year, growth remained robust at over 6 percent in 2007 and macroeconomic stability has been maintained; however, internal and external emerging imbalances have developed. Inflation has increased to 9 percent from 5.3 percent in 2006, reflecting rising international food and oil prices. Also, despite an improvement in the terms of trade and good export performance, the external current account deficit almost doubled, to 10 percent of GDP, due to rapid growth in imports. Net international reserves slightly declined in 2007, but that trend has been recently reversed. At the same time, the overall fiscal deficit deteriorated, partly reflecting rising current spending, including wages (due to teacher's agreements), and the weakening finances of the public companies, particularly the electricity company (ENEE).

\section{Program Summary}

The authorities' economic program for 2008 is designed to sustain continued high growth and contain inflation within a less favorable external environment. A set of fiscal, monetary, 
and prudential policy measures aims at addressing the emerging macroeconomic imbalances, and placing the energy sector on a sustainable footing.

Fiscal consolidation and reorientation. The overall fiscal deficit will be reduced to 1.5 percent of GDP in 2008 from 2.3 percent in 2007 through a mix of revenue and expenditure measures. On the expenditure side, the government has committed to keep a cautious control on current primary spending of the central government. At the same time, the program allows for a substantial increase in public investment, particularly in infrastructure projects to reduce bottlenecks in the electricity and transportation sectors. The authorities are also improving the targeting of electricity and direct fuel subsidies to the poor.

Containing inflation and safeguarding external stability. The monetary program seeks to avoid the second round effects of food and energy prices and wage increases and maintain inflation in a range of 8-10 percent. The program also contains measures to encourage banks to tackle with the rapid growth in credit and bring it down to more sustainable levels. The program also aims to build net international reserves by US\$253 million, to keep a coverage around of 4 months of nonmaquila imports.

Strengthening the energy sector. Reforming the electricity sector is fundamental to create the appropriate conditions to attract investment and support growth, besides safeguarding public finances. In cooperation with the World Bank and the Inter-American Development Bank (IADB), the authorities will implement a plan to reduce energy distribution losses and fraud; stimulate and reactivate investment in the sector; improve the finances of ENEE and clear its arrears with electricity generators. 